Prepared in cooperation with the Whatcom County Flood Control Zone District

\title{
Sediment Storage and Transport in the Nooksack River Basin, Northwestern Washington, 2006-15
}

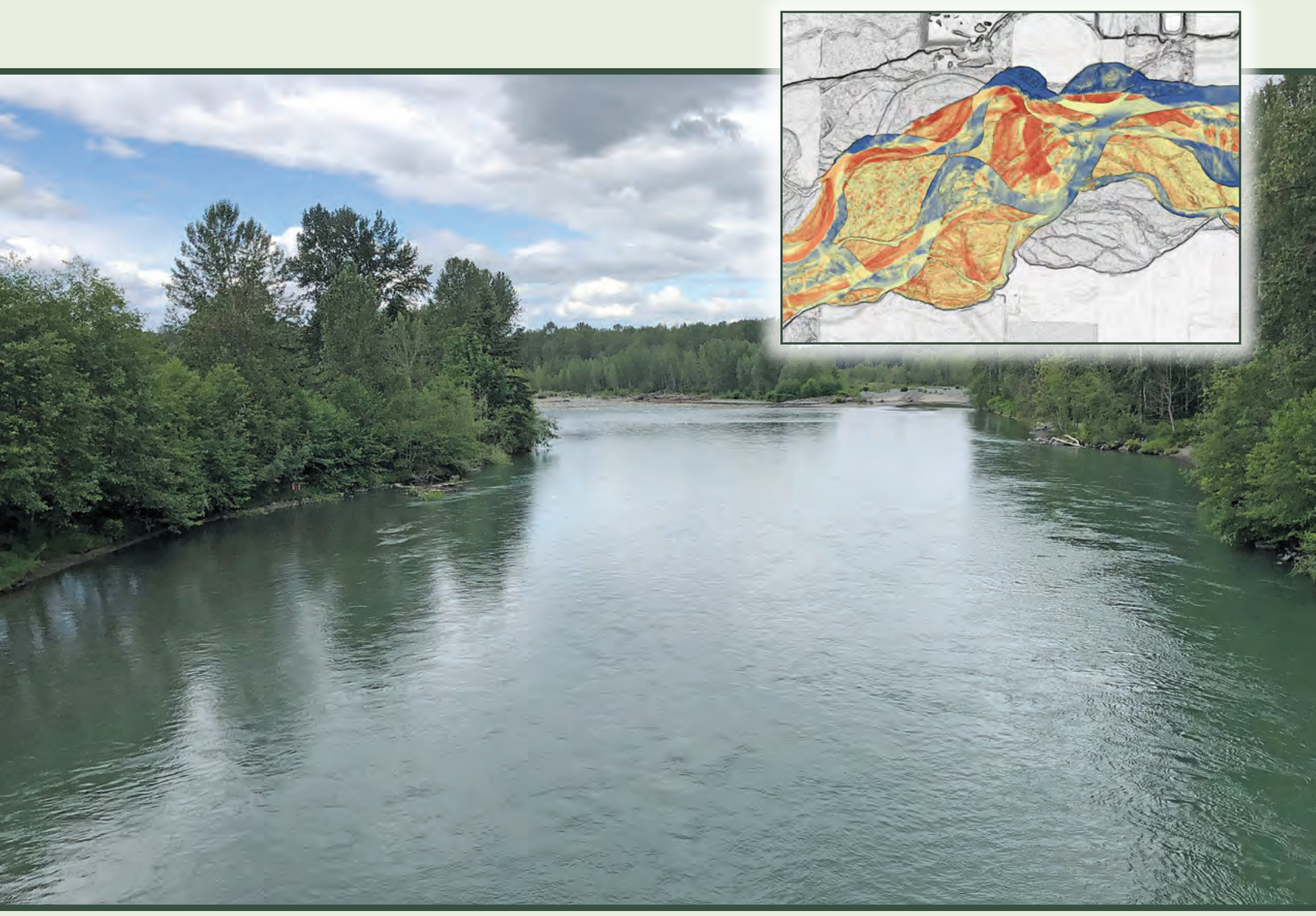

Scientific Investigations Report 2019-5008 


\section{Cover:}

Center: Nooksack River at North Cedarville, Washington, looking downstream

Photograph by Chris Curran, U.S. Geological Survey, 2018.

Inset: Digital elevation model of topographic change from 2006 to 2013, river mile 24,

Nooksack River, Washington. Image is taken from figure 7 of this report. 


\section{Sediment Storage and Transport in the Nooksack River Basin, Northwestern Washington, 2006-15}

By Scott W. Anderson, Christopher P. Konrad, Eric E. Grossman, and Christopher A. Curran

Prepared in cooperation with the Whatcom County Flood Control Zone District

Scientific Investigation Report 2019-5008 


\title{
U.S. Department of the Interior \\ DAVID BERNHARDT, Acting Secretary
}

\author{
U.S. Geological Survey \\ James F. Reilly II, Director
}

U.S. Geological Survey, Reston, Virginia: 2019

For more information on the USGS - the Federal source for science about the Earth, its natural and living resources, natural hazards, and the environment-visit https://www.usgs.gov or call 1-888-ASK-USGS.

For an overview of USGS information products, including maps, imagery, and publications,

visit https://store.usgs.gov.

Any use of trade, firm, or product names is for descriptive purposes only and does not imply endorsement by the U.S. Government.

Although this information product, for the most part, is in the public domain, it also may contain copyrighted materials as noted in the text. Permission to reproduce copyrighted items must be secured from the copyright owner.

Suggested citation:

Anderson, S.W., Konrad, C.P., Grossman, E.E., and Curran, C.A., 2019, Sediment storage and transport in the Nooksack River basin, northwestern Washington, 2006-15: U.S. Geological Survey Scientific Investigations Report 2019-5008, 43 p., https://doi.org/10.3133/sir20195008.

ISSN 2328-0328 


\section{Contents}

Abstract

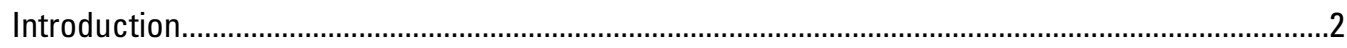

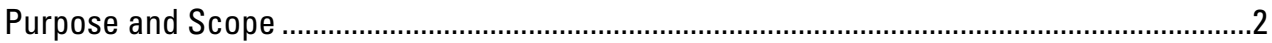

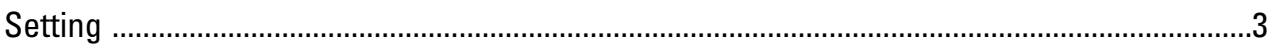

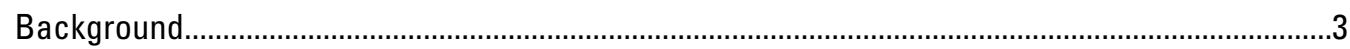

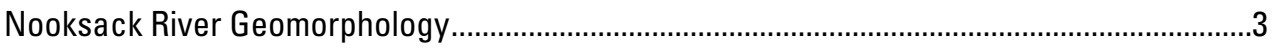

Previous Estimates of Sediment Loads and Changes in Sediment Storage ...........................3

Reference System for River Locations..................................................................................

Channel Change Since 2006 Based On Repeat Surveys .................................................................

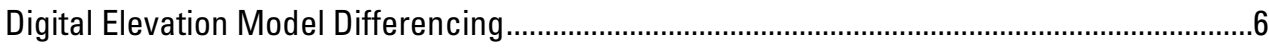

Uncertainty In Topographic Differencing ................................................................

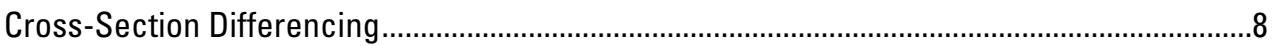

Longitudinal Changes in Mean Elevation ..................................................................................

Volumetric Change in Sediment Storage ……………............................................................

Channel as a Source of Sediment Load .....................................................................10

Long-Term Trends in River Bed Elevation at U.S. Geological Survey Streamgages .......................15

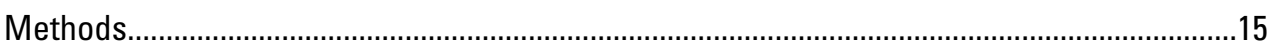

Changes in Stage-Discharge Relations ........................................................................ 17

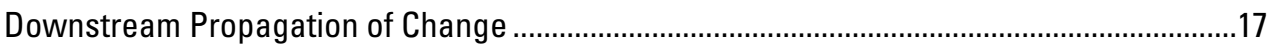

Bed Change Propagation Rates ...................................................................................19

Observed Versus Estimated Vertical Change Based On Repeat Topography and Streamgage Analysis, 2006-13 ....................................................................19

Relations Between Regional Climate and Propagated Pattern of Bed Change.....................19

Characterizing Regional Climate ...................................................................................

Regional Climate and Bed Elevation Trends................................................................21

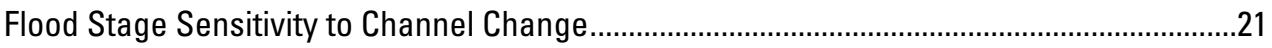

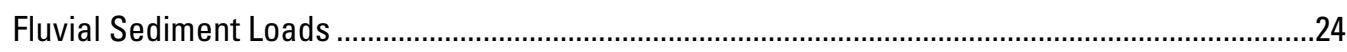

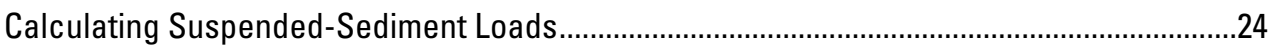

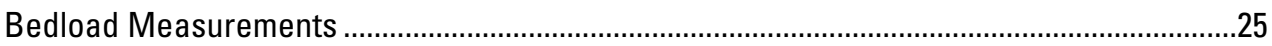

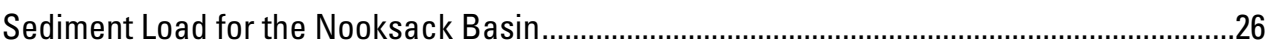

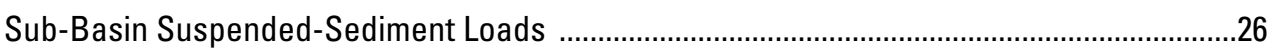

Suspended-Sediment Balance in the Mainstem Nooksack..............................................30

Consistency of Suspended-Sediment-Content-Discharge Relations over Time ....................32

Floodplain Drainage and Recent Trends in Precipitation, Streamflow, and Stage .........................32

Trends in Monthly Precipitation, Streamflow and Stage ............................................................

Areas Susceptible to Drainage Issues With Increased Stage ..................................................34

Dynamics of Water-Surface Elevations, River Bed Elevations, and Suspended-Sediment Transport in the Lower Mainstem Nooksack River ..............................................................36

Relations Between Water-Surface Elevations at Ferndale, Brennan, and Marine Drive .......36

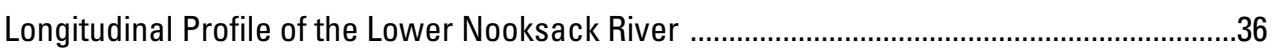

Seasonal- and Storm-Scale Patterns in Turbidity at Ferndale ...............................................38

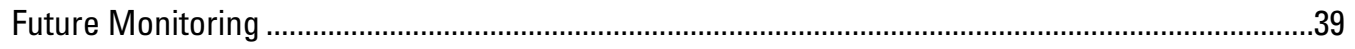




\section{Contents}

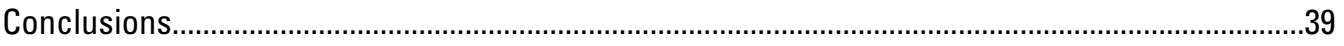

Changes in Channel Storage from 2005/06 to 2013/15 .....................................................39

Magnitude of Net Channel Change Relative to Sediment Transport Rates ....................40

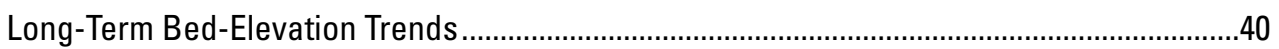

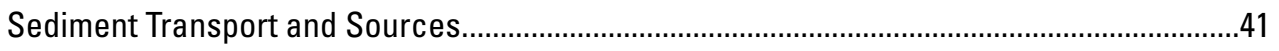

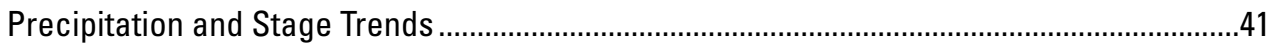

Storm- and Seasonal-Scale Patterns of Sediment Transport..................................................41

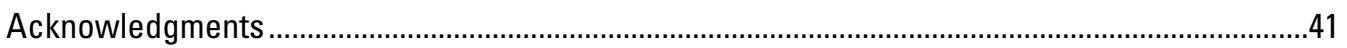

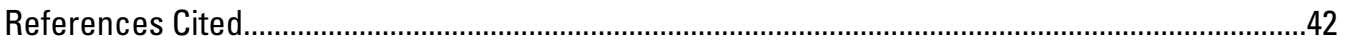

\section{Figures}

1. Map showing study area, Nooksack River basin, northwestern Washington

2. Map showing spatial extent of topographic and bathymetric data used in analysis of geomorphic change, Nooksack River basin, northwestern Washington, 2006-15.

3. Graph showing bias in 2006 lidar as a function of mean vegetation height, Nooksack River, northwestern Washington.

4. Graph showing raw and corrected volumetric change estimates based on repeat aerial lidar by river mile, Nooksack River, northwestern Washington, 2005-13. Volumetric change is calculated over regular 650-foot-long polygons that span the 2005/06-2013 geomorphically active river corridor. WSE, water-surface elevation; Veg, vegetation

5. Graphs showing mean vertical change in elevation in the Nooksack River, northwestern Washington, 2005-15

6. Graphs showing cumulative net volumetric change based on repeat aerial lidar $(A)$ and geomorphically active channel width $(B)$, Nooksack River basin, northwestern Washington, 2005/06-13.

7. Digital elevation model of topographic change from 2006 to 2013 , based on differencing of repeat aerial lidar, from river mile 20 to 29, Nooksack River, northwestern Washington, 2006-13.

8. Digital elevation model of topographic change from 2006 to 2013 , based on differencing of repeat aerial lidar, from river mile 28 to 33, Nooksack River, northwestern Washington, 2006-13.

9. Maps showing digital elevation model of topographic change from 2005 to 2013, based on differencing of repeat aerial lidar, from river mile 33 to 43.

10. Graphs showing changes in stage-discharge relations at all U.S. Geological Survey streamgages in the $(A)$ South Fork, $(B)$ Middle Fork, and $(C)$ North Fork and mainstem Nooksack River, northwestern Washington, 2005-15.

11. Graph showing changes in stage-discharge relations at all streamgages in the North Fork and mainstem Nooksack River, lagged to align with the upstream-most streamgage on the North Fork Nooksack River (12205000), northwestern Washington, 1938-2018

12. Graph showing propagation rate for bed-wave as a function of channel slope, Nooksack River basin, northwestern Washington ...

13. Graph showing comparison of measured bed-elevation change and forecasted bed-elevation change in the Nooksack River, northwestern Washington, 2005-06 to $2013-15$. 


\section{Figures-Continued}

14. Graphs showing regional climate index based on mean annual temperature and total precipitation, Nooksack River, northwestern Washington, 1895-2016..

15. Graphs showing changes in stage-discharge relations and regional climate index, Nooksack River, northwestern Washington, 1900-2018.

16. Graphs showing relation between changes in stage-discharge relations at low to moderate discharges and concurrent changes in stage-discharge relations at high discharges at $(A)$ Nooksack River at Ferndale, Washington (U.S. Geological Survey streamgage 12213100) and (B) Nooksack River at Deming, Washington (U.S. Geological Survey streamgage 12210500), Nooksack River, northwestern Washington, 2005-15..

17. Graphs showing example of gap-filling used to form complete daily records of suspended-sediment concentrations (SSC) and suspended-sediment loads (SSL) at glacially influenced sites, using data from Nooksack River at Ferndale, Washington (U.S. Geological Survey streamgage 12213100).

18. Graph showing cumulative sediment loads at Nooksack River at Ferndale, Washington (U.S. Geological Survey streamgage 12213100), October 1, 2011, to September 30, 2017

19. Graphs showing cumulative fraction of suspended-sediment load as a function of daily mean discharge at $(A)$ Nooksack River at Ferndale, Washington (U.S. Geological Survey [USGS] streamgage 12213100); Nooksack River at Ferndale; $(B)$ Middle Fork Nooksack River near Deming, Washington (USGS streamgage 12208000); and (C) South Fork Nooksack River at Saxon Bridge, Washington (USGS streamgage 12210000).

20. Maps showing suspended-sediment loads and yields in the Nooksack River by sub-basin, northwestern Washington.

21. Graphs showingdischarge and cumulative suspended-sediment load at Nooksack River at Ferndale, Washington (U.S. Geological Survey [USGS] streamgage 12213100), 2012-16 (A), and cumulative load imbalance in the lower river, defined as the difference between the load at Nooksack River at Ferndale, Washington, and the load at Nooksack River at North Cedarville, Washington (U.S. Geological Survey streamgage USGS 12210700), (B) northwestern Washington..31

22. Graphs showing comparison of suspended-sediment-discharge $(A)$ at Nooksack River at North Cedarville, Washington (U.S. Geological Survey streamgage 12210700 ) and $(B)$ at Nooksack River at Ferndale, Washington (U.S. Geological Survey streamgage 12213100)

23. Elevation of land surface above water surface of Nooksack River from 2013 lidar, northwestern Washington.

24. Graphs showing relations between water-surface elevations at $(A)$ Nooksack River at Ferndale, Washington (U.S. Geological Survey [USGS] streamgage 12213100) and Nooksack River at Brennan, Washington (USGS streamgage 12213140), and (B) Nooksack River at Marine Drive Bridge near Bellingham, Washington (USGS streamgage 12213145)

25. Longitudinal profile of the Nooksack River over a range of streamflow values, northwestern Washington.

26. Graphs showing turbidity and discharge at Nooksack River at Ferndale, Washington (U.S. Geological Survey streamgage 12213100) for selected storms 


\section{Tables}

1. Location of sites referenced in this study, Nooksack River basin, northwestern Washington, 2006-15.

2. Topographic data used for change analysis, Nooksack River basin, northeastern Washington, 2006-15.

3. Corrections applied to lidar, Nooksack River, northwestern Washington, 2005 and 2006 .

4. Volumetric change from $2005 / 06$ to 2013 for various sub-reaches, Nooksack River, northwestern Washington, 2006-15.

5. Bed material supplied by net erosion of the channel upstream of Nugent's Corner, Nooksack River basin, northwestern Washington, 2006-15

6. Streamgages used in this report, Nooksack River basin, northwestern Washington, 2006-15.

7. Cross-correlation analysis of stage-discharge changes at U.S. Geological Survey streamgages on the North Fork and mainstem Nooksack River, northwestern Washington, 2006-15

8. Bed wave propagation rates for all valid streamgage pairs, Nooksack River basin, northwestern Washington, 2006-15.

9. Annual suspended-sediment loads at streamgages, Nooksack River basin, northwestern Washington, 2006-15

10. Summary of bedload measurements made at Nooksack River at Ferndale, Washington (U.S. Geological Survey streamgage 12213100), 2017

11. Summary of mean annual sediment load of Nooksack River at Ferndale, Washington (U.S. Geological Survey streamgage 12213100), water years 2012-17 ......28

12. Trends indicated by Pearson product-moment correlation coefficients for annual values of precipitation, streamflow, and stage statistics with year, Nooksack River basin, northwestern Washington, 1981-2013 


\section{Conversion Factors}

U.S. customary units to International System of Units

\begin{tabular}{lcl}
\hline \multicolumn{1}{c}{ Multiply } & By & \multicolumn{1}{c}{ To obtain } \\
\hline foot $(\mathrm{ft})$ & Length & meter $(\mathrm{m})$ \\
mile $(\mathrm{mi})$ & 0.3048 & kilometer $(\mathrm{km})$ \\
yard $(\mathrm{yd})$ & 1.609 & meter $(\mathrm{m})$ \\
\hline & 0.9144 & \\
\hline square mile $\left(\mathrm{mi}^{2}\right)$ & Area & square kilometer $\left(\mathrm{km}^{2}\right)$ \\
\hline & 2.590 & \\
\hline cubic foot $\left(\mathrm{ft}^{3}\right)$ & Volume & cubic meter $\left(\mathrm{m}^{3}\right)$ \\
cubic yard $\left(\mathrm{yd}^{3}\right)$ & 0.02832 & cubic meter $\left(\mathrm{m}^{3}\right)$ \\
\hline & 0.7646 & \\
\hline cubic foot per second $\left(\mathrm{ft}^{3} / \mathrm{s}\right)$ & Flow rate & cubic meter per second $\left(\mathrm{m}^{3} / \mathrm{s}\right)$ \\
mile per hour $(\mathrm{mi} / \mathrm{h})$ & 0.02832 & kilometer per hour \\
mile per year $(\mathrm{mi} / \mathrm{yr})$ & 1.609 & kilometer per year $(\mathrm{km} / \mathrm{yr})$ \\
\hline & 1.609 & \\
\hline pound, avoirdupois $(\mathrm{lb})$ & Mass & kilogram $(\mathrm{kg})$ \\
ton, short $(2,000 \mathrm{lb})$ & 0.4536 & metric ton $(\mathrm{t})$ \\
\hline
\end{tabular}

International System of Units to U.S. customary units

\begin{tabular}{lcl}
\hline \multicolumn{1}{c}{ Multiply } & By & \multicolumn{1}{c}{ To obtain } \\
\hline & Length & \\
\hline millimeter $(\mathrm{mm})$ & 0.0393 & inch (in) \\
kilometer $(\mathrm{km})$ & 0.6213 & mile (mi) \\
\hline
\end{tabular}

Temperature in degrees Fahrenheit $\left({ }^{\circ} \mathrm{F}\right)$ may be converted to degrees Celsius $\left({ }^{\circ} \mathrm{C}\right)$ as follows:

$$
{ }^{\circ} \mathrm{C}=\left({ }^{\circ} \mathrm{F}-32\right) / 1.8 \text {. }
$$

\section{Datums}

Vertical coordinate information is referenced to the North American Vertical Datum of 1988 (NAVD 88).

Horizontal coordinate information is referenced to the North American Datum of 1983 (NAD 83).

Elevation, as used in this report, refers to distance above the vertical datum.

\section{Supplemental Information}

Concentrations of chemical constituents in water are given in either milligrams per liter ( $\mathrm{mg} / \mathrm{L}$ ) or micrograms per liter $(\mu \mathrm{g} / \mathrm{L})$. 



\title{
Sediment Storage and Transport in the Nooksack River Basin, Northwestern Washington, 2006-15
}

\author{
By Scott W. Anderson, Christopher P. Konrad, Eric E. Grossman, and Christopher A. Curran
}

\section{Abstract}

The Nooksack River is a dynamic gravel-bedded river in northwestern Washington, draining off Mount Baker and the North Cascades into Puget Sound. Working in cooperation with the Whatcom County Flood Control Zone District, the U.S. Geological Survey studied topographic, hydrologic, and climatic data for the Nooksack River basin to document recent changes in sediment storage, long-term bed elevation trends, rates of sediment transport, and factors influencing surficial drainage in order to support ongoing river management. Differences in elevations between topographic and bathymetric surveys in 2005/06 and 2013/15 indicate the active channel aggraded about 1-2 feet locally near the cities of Ferndale and Everson but was primarily stable between them. The active channel upstream of Nugent's Corner generally incised. Total incision upstream of Nugent's Corner to Glacier Creek generated $2.3 \pm 1.7$ million cubic yards

of sediment from 2005/06 to 2013 and likely represented a significant source of coarse sediment to the lower mainstem river over that time.

Long-term records of local channel-bed elevation, derived from U.S. Geological Survey streamgage data, show bed-elevation changes of about 1-3 feet. The river bed at most streamgages exhibits long-term trends, with relatively consistent rates of change on the order of 1 foot per decade that persist years to decades. Lagged correlations in bedelevation trends at all seven streamgages in the North Fork Nooksack and mainstem Nooksack suggest that decadal periods of persistent aggradation and incision originate in the North Fork and translate downstream. The channel-change signal propagates downstream 0.5-2.5 miles per year, with the rate of propagation scaling closely with channel slope. The pattern of incision and aggradation in the North Fork correlates with regional climate, where persistent incision follows extended cold and wet periods, and persistent aggradation follows extended warm and dry periods. Climatedriven variation in coarse-sediment delivery, primarily from the North Fork Nooksack, then appears to be a strong control on long-term vertical channel adjustments at sites downstream. The downstream-translating climate signal generated in the North Fork would account for recently observed aggradation at Everson and Ferndale but not the observed incision in unconfined reaches upstream of Nugent's Corner from 2005-06 to 2013. This mismatch indicates that understanding how changes in sediment-supply influence those unconfined reaches remains a key uncertainty for predicting future channel change.

Continuous turbidity monitoring integrated with suspended sediment and limited bedload sampling were used to calculate annual sediment loads at five sites in the basin. The sediment load in the lower river at Ferndale ranged from 0.78 to 1.17 million tons per year and averaged 0.97 million tons per year for WYs 2012-17. Suspended sediment made up 93 percent of the load, and bedload made up 7 percent. Most of the fine sediment load of the lower river is supplied from headwaters of the North, Middle, and South Fork Nooksack basins, with relatively little net increase in fine sediment loads in the lower mainstem basin. The three forks supply approximately equal proportions of the lower-river fine sediment load. However, the glacially sourced North and Middle Fork Nooksack basins carry a notably sandier suspended-sediment load than the South Fork Nooksack.

A comparison of monthly streamflow and precipitation trends since 1981 indicate statistically significant increases in total spring precipitation and the number of spring days with measurable precipitation in much of the basin, as well as increases in mean spring river stage near Ferndale. Since no trends in mean spring discharge are observed, the trends in river stage are attributed primarily to observed changes in bed elevation. Changes in bed elevation and precipitation may then both have plausibly impacted field drainage in the lower river below Ferndale. 


\section{Introduction}

The Nooksack River flows from the eastern North Cascade Range in Washington state, United States, and southern British Columbia, Canada, to Bellingham Bay and the Salish Sea (fig. 1). Much of the historic floodplain along the mainstem has agricultural, residential, or commercial development, which can be affected by flooding. The river is important for salmon and salmon-recovery efforts in Puget Sound and is an important natural and cultural resource for the Lummi and Nooksack Tribes, which have reservations in the basin. As a result, there is broad interest in how changes in sediment storage in the river channel and its floodplain affect channel morphology, flooding and drainage, navigability of the river for fishing, and river-floodplain habitats.

\section{Purpose and Scope}

This investigation provides information on recent rates of sediment transport and storage in the Nooksack River corridor and advances the current understanding of how these processes affect the elevation of the river bed from the North
Fork to the delta. There are three primary questions addressed in this report by integrating information from topographic surveys, streamflow gaging, suspended-sediment monitoring, and stage monitoring:

1. How has the volume of sediment stored in the active channel of the lower North Fork and mainstem Nooksack changed since 2006? This question encompasses the magnitude and spatial distribution of those changes and is addressed by comparing topography and bathymetry derived from airborne (lidar and photogrammetric) and field surveys in 2005 and 2006 to topography and bathymetry derived from surveys in 2013 and 2015.

2. How do the recent patterns of sediment storage in lower North Fork and mainstem Nooksack River relate to longer-term trends and the broader basin-scale context? This question is addressed through analysis of changing stage-discharge relations at streamgages, which provides decades-long proxies for changing bed elevations at multiple locations in the basin, and by quantifying suspended-sediment loads (SSL) from the three major tributaries and at two mainstem locations.

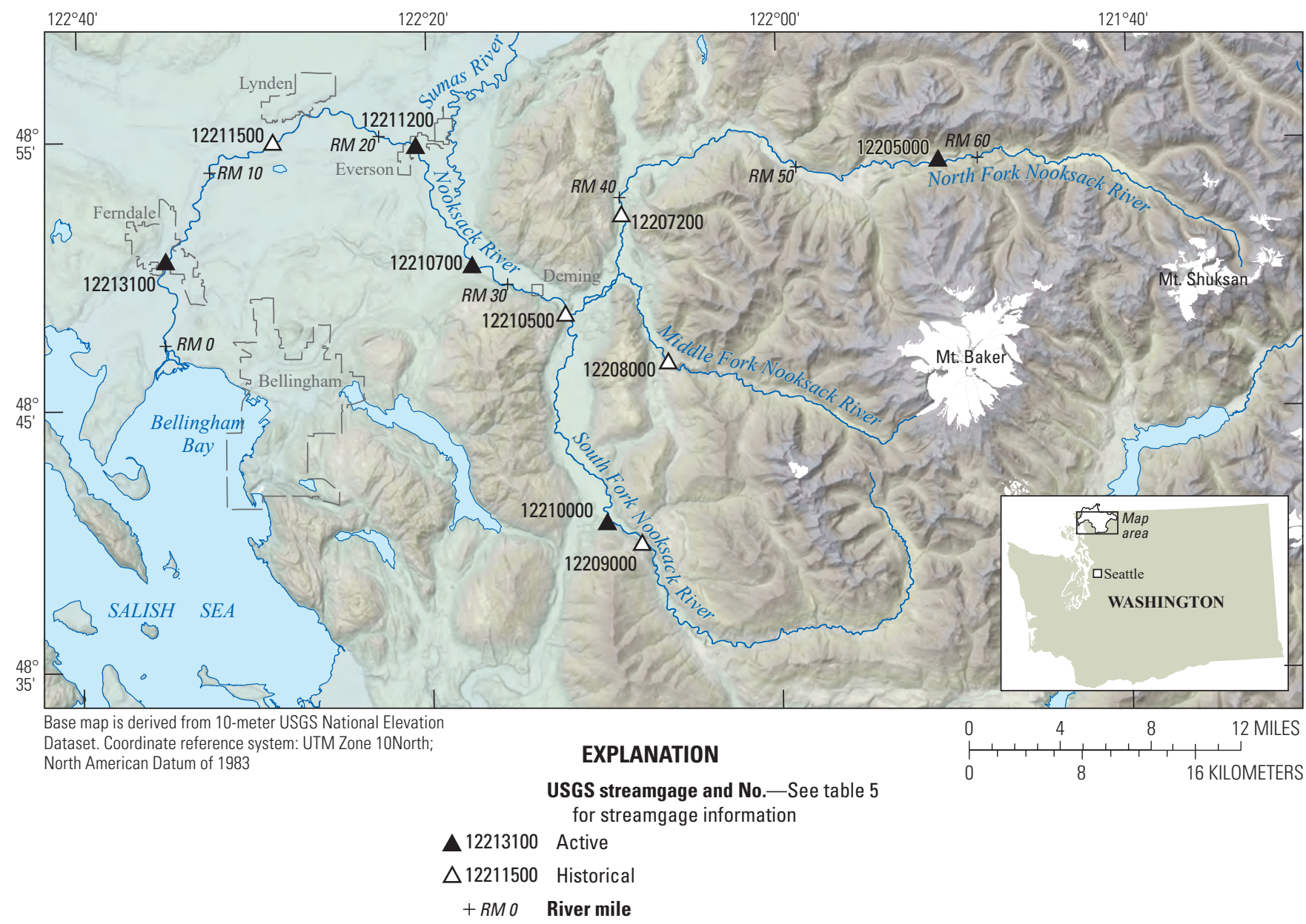

Figure 1. Study area, Nooksack River basin, northwestern Washington. U.S. Geological Survey streamgages used in this report are indicated. 
3. What factors beyond bed-elevation change could contribute to flooding and drainage issues observed over the past decades? This question is addressed by testing for trends in precipitation, streamflow, and stage at selected locations in the basin and by examining seasonal- and storm-scale dynamics of suspendedsediment transport and stage in the mainstem Nooksack downstream of Ferndale.

The analyses presented here are intended to document recent channel change, to provide an improved understanding of how sediment is sourced and routed down the river, and to guide approaches for continued monitoring that can be targeted to locations where change is either occurring or where change would be particularly problematic.

\section{Setting}

The Nooksack River basin is approximately 790 square miles $\left(\mathrm{mi}^{2}\right)$ and extends from the summit of Mount Baker $(10,400$ feet $[\mathrm{ft}])$ to Bellingham Bay, a part of the Salish Sea (fig. 1). The river has three main tributaries, which drain montane, conifer forests of the western North Cascades: the North Fork (280 $\left.\mathrm{mi}^{2}\right)$, the Middle Fork $\left(100 \mathrm{mi}^{2}\right)$, and the South Fork $\left(190 \mathrm{mi}^{2}\right)$. The North Fork receives runoff and sediment from Colman, Roosevelt, and Sholes glaciers on the north side of Mount Baker and mountains along the northern United States border with Canada. The Middle Fork drains the western flank of Mount Baker, including the Deming glacier. The South Fork drains lower-elevation terrain between Mount Baker and the Skagit River. The forks join in a glacial trough around Deming, where the mainstem then flows through a gap in the western edge of the Cascades into a broad lowland valley that extends north to the Frasier River and west to the Strait of Georgia.

\section{Background}

\section{Nooksack River Geomorphology}

The lower mainstem Nooksack River has a single-thread, sinuous channel confined by levees for much of its length downstream of river mile (RM) 22, near the town of Everson (fig. 1). The mainstem river becomes much wider upstream of Everson and takes on an alternately braided or sinuous channel planform, depending on local valley confinement. The North and Middle Forks have alternating sinuous, single-thread, and braided reaches, which again correspond to confined and unconfined valley segments. The South Fork mostly has a single-thread, sinuous channel. The gradient of the Nooksack River decreases from 0.004 around the confluence of the
North and Middle Fork to 0.002 around Everson and 0.0002 downstream of Ferndale. The dominant bed material varies along the river network from boulders in steep headwater reaches to fine gravel and sand in unconfined reaches and the reach downstream of Ferndale. Sand and gravel bars are emergent at low to moderate flow in the active channel along the mainstem upstream of Lynden and each of the forks.

It is likely that, during the early Holocene, the mainstem Nooksack flowed north into the Fraser River through the current valley of the Sumas River and that the current river course, draining west into Bellingham Bay, was the result of an avulsion near the town of Everson sometime in the past several thousand years (Pittman and Maudlin, 2003). The drainage divide between the current Nooksack and Sumas Rivers at this proposed avulsion site remains low and is often overtopped during high flows, causing flooding in the Sumas Valley and directing flood waters north into Canada (KCM, Inc., 1995).

The Nooksack River was historically mined for river gravel, primarily between RM 14 and 22 (downstream of the town of Lynden to near Everson). Kerr Wood Leidal (2008) reported mean permitted gravel removal of 80,000 tons per year from 1964 to 1987 , growing from 1960 to the early 1970 s and then declining until the late 1980s. Gravel extraction increased significantly between 1990 and 1993 to an average of about 240,000 tons per year, but then declined and ultimately stopped in 1997.

\section{Previous Estimates of Sediment Loads and Changes in Sediment Storage}

Sediment loads and changes in storage have been estimated for the Nooksack River at various times in previous investigations. Czuba and others (2011), summarizing studies by Wise and others (2007) and Embrey and Frans (2003), estimated a mean annual SSL of 1.4 million tons per year for the lower Nooksack River. This corresponds to an annual sediment yield of about 1,650 tons per square mile per year (tons $/ \mathrm{mi}^{2} / \mathrm{yr}$ ), the highest per-area yield of the 14 major Puget Sound rivers considered by Czuba and others (2011). Northwest Hydraulic Consultants (2015) converted an estimate of delta growth of 650 million cubic yards from 1855 to 1956 into a minimum average annual sediment transport rate of 3.2 million tons per year over that period.

Kerr Wood Leidal (2008) analyzed photogrammetric digital elevation models (DEMs) of the Nooksack River from 1996 to 2002 and found no statistically significant change in sediment storage in two 2-mile sub-reaches between Everson and Deming. Longer-term bed elevation trends downstream of Everson, based on sparse repeat cross-sections, were qualitatively assessed as indicating minimal vertical change in the lower river from about 1987 to 2006 . 
Northwest Hydraulic Consultants (2015) describe recent geomorphic changes in the lower river below Ferndale, including changes associated with large floods in water years ${ }^{1}$ (WYs) 2006, 2009, and 2011. From 2006 to 2009, river switched from left distributary to main right distributary at Marietta Channel at the mouth of the river. These channels continued to widen through 2014. Wood and sediment have been accumulating at the point where the river bifurcates. Northwest Hydraulic Consultants noted breaches forming in the left bank levee upstream of Marine Drive (RM 0; table 1). They conclude that conveyance efficiency of the delta has decreased but would increase if the central distributary expands.

\section{Reference System for River Locations}

Locations along the Nooksack River are referenced in this report using a valley centerline, delineated using 2013 aerial lidar. The upstream edge of the Marine Drive Bridge was used to define a stable RM 0 . Table 1 indicates the river mile of prominent locations. These locations are grouped into four broad reaches, numbered one to four, in upstream order, with similar reach-scale characteristics (these reach groupings are commonly used by Whatcom County for analysis and discussion). The study covered in this report included an additional fifth reach upstream of Deming.

\section{Channel Change Since 2006 Based On Repeat Surveys}

Channel change in the mainstem and North Fork Nooksack River was assessed based on repeat topographic and bathymetric surveys (fig. 2; table 2). Upstream of RM 19 , aerial lidar surveys collected in 2005, 2006, and 2013 were differenced to generate spatially continuous DEMs of difference (DoDs), providing qualitative and quantitative information on elevation changes in the active channel of the river. The methods of developing those DoDs are described in detail in section, "Digital Elevation Model Differencing." Those DoDs were used to assess spatial patterns of volumetric change in sediment storage and changes in mean elevation across the entire width of the active channel, as well as changes in the elevation of the low-flow water surface.

\footnotetext{
${ }^{1}$ The 12-month period from October 1, for any given year, through September 30 of the following year. The water year is designated by the calendar year in which it ends.
}

Downstream of RM 19, change was assessed based on a comparison of 2006 cross-sections and cross-sections cut from a continuous bathymetric surface collected in 2015 (Anderson and Grossman, 2017). Methods for calculating changes in mean bed elevation at cross-sections are described in detail in section, "Cross-Section Differencing." Repeat cross-sections were used solely to determine changes in mean elevation and were not extrapolated to estimate volumetric change. Repeat cross-sections from RM 19 to 23, overlapping the extents of repeat aerial lidar, were available and used to cross-validate the results of the two data sources.

Table 1. Location of sites referenced in this study, Nooksack River basin, northwestern Washington, 2006-15.

[Study area and river-mile markers shown in figure 1. Abbreviations: WA, Washington; bl, below; nr, near; USGS, U.S. Geological Survey]

\begin{tabular}{|c|c|c|}
\hline Reach & Location & River mile \\
\hline \multirow[t]{4}{*}{1} & Marine Drive & 0.0 \\
\hline & Slater Road & 2.2 \\
\hline & $\begin{array}{l}\text { USGS streamgage } 12213100 \text { (Nooksack } \\
\text { River at Ferndale, WA) }\end{array}$ & 4.7 \\
\hline & Reach $1 / 2$ boundary & 5.4 \\
\hline \multirow[t]{3}{*}{2} & Bertrand Creek & 11.3 \\
\hline & 539 Bridge & 14.0 \\
\hline & Reach $2 / 3$ boundary & 14.0 \\
\hline \multirow[t]{5}{*}{3} & Lynden & 16.5 \\
\hline & HWY 544 Bridge & 21.9 \\
\hline & Everson & 21.9 \\
\hline & $\begin{array}{l}\text { USGS streamgage } 12211200 \text { (Nooksack } \\
\text { River at Everson, WA) }\end{array}$ & 21.9 \\
\hline & Reach $3 / 4$ boundary & 21.9 \\
\hline \multirow[t]{7}{*}{4} & Nuggents Corner & 28.0 \\
\hline & $\begin{array}{l}\text { USGS streamgage } 12210700 \\
\text { (Nooksack River at Cedarville, WA) }\end{array}$ & 28.0 \\
\hline & Clay Banks Landslide & 29.5 \\
\hline & Deming & 31.8 \\
\hline & $\begin{array}{l}\text { USGS streamgage } 12210500 \text { (Nooksack } \\
\text { River at Deming, WA) }\end{array}$ & 33.2 \\
\hline & South Fork Nooksack confluence & 33.3 \\
\hline & Reach $4 / 5$ boundary & 33.3 \\
\hline \multirow[t]{6}{*}{5} & Middle Fork Nooksack confluence & 36.1 \\
\hline & Racehorse Creek & 40.1 \\
\hline & 542 Bridge near Warnick & 49.2 \\
\hline & Glacier Creek Confluence & 51.9 \\
\hline & $\begin{array}{l}\text { USGS Streamgage } 12205000 \text { (North } \\
\text { Fork near NF Nooksack River bl } \\
\text { Cascade Creek nr Glacier, WA) }\end{array}$ & 57.4 \\
\hline & Wells Creek-Falls & 59.3 \\
\hline
\end{tabular}




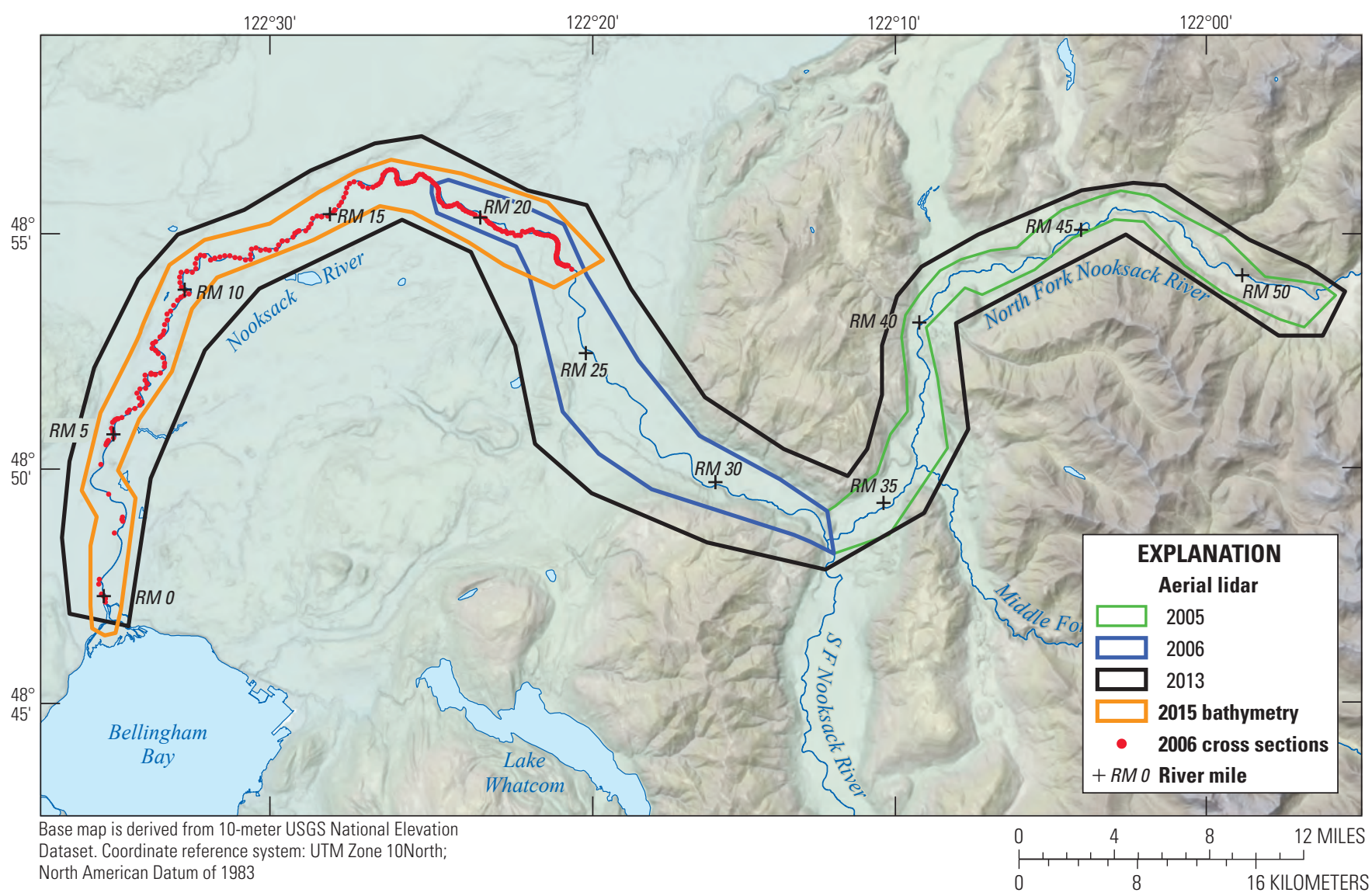

Figure 2. Spatial extent of topographic and bathymetric data used in analysis of geomorphic change, Nooksack River basin, northwestern Washington, 2006-15.

Table 2. Topographic data used for change analysis, Nooksack River basin, northeastern Washington, 2006-15.

[Abbreviations: ft, foot; PSLC, Puget Sound Lidar Consortium; RM, river mile; -, not applicable]

\begin{tabular}{|c|c|c|c|c|c|c|}
\hline $\begin{array}{c}\text { Topographic } \\
\text { dataset }\end{array}$ & $\begin{array}{l}\text { Collection } \\
\text { date }\end{array}$ & $\begin{array}{c}\text { Total } \\
\text { extents }\end{array}$ & $\begin{array}{l}\text { Utilized } \\
\text { extents }\end{array}$ & $\begin{array}{l}\text { Horizontal } \\
\text { resolution } \\
\quad(\mathrm{ft})\end{array}$ & Source & Notes \\
\hline $\begin{array}{r}2006 \text { cross } \\
\text { sections }\end{array}$ & Unknown & RM 33.3-0 & RM 23-0 & - & $\begin{array}{l}\text { Whatcom } \\
\text { County }\end{array}$ & $\begin{array}{l}\text { Longitudinal spacing ranges from every } \\
100 \mathrm{ft} \text { near Everson to every mile } \\
\text { downstream of Ferndale. Most reaches } \\
\text { have cross sections every } 700-800 \mathrm{ft} \text {. }\end{array}$ \\
\hline 2013 lidar & $\begin{array}{l}\text { Mainstem: January 15, } \\
2013 \\
\text { North Fork: March 31, } \\
\text { 2013-April 16, } 2013\end{array}$ & RM 60-0 & RM 52-0 & 3 & PSLC & \\
\hline
\end{tabular}




\section{Digital Elevation Model Differencing}

All differencing of aerial lidar data was performed using bare-earth rasterized DEMs with either 6-foot (2005 and 2006) or 3-foot (2013) grid spacing. Prior to differencing, all DEMs were first projected into North American Datum of 1983 Universal Transverse Mercator zone 10N coordinates and resampled to a common 6-foot grid. All surveys contained elevations referenced to the North American Vertical Datum of 1988, using GEOID03 to convert ellipsoidal elevations to orthometric elevations. Potential systematic errors in vertical registration were assessed based on measured change along paved roads within the areas of overlap, where the true change is assumed to have been zero. For all DEMs pairs, relative vertical offsets on the order of $0.05-0.50 \mathrm{ft}$ were identified and removed by shifting the earlier of the two DEMs into alignment with the later (table 3 ).

The discharge of the Nooksack River differed appreciably between dates of lidar acquisition, resulting in a component of volumetric change in the DoDs related solely to differences in river stage and water storage. This river stage-dependent volumetric change was approximately removed by adjusting the elevation of the water-surface area in the 2005 and 2006 lidar surveys to match discharge conditions of the 2013 lidar. These correction factors were estimated as the average stagechange expected at the Everson (USGS 12211200), North Cedarville (USGS 12210700), and Deming (USGS 12210500) streamgages for the differing discharges. Because the exact date of the 2006 lidar was unknown, discharge-dependent differences in stage were estimated by comparing the 2005 and 2006 water-surface profiles over the extent of overlap. A systematic offset of about $1 \mathrm{ft}$ between the two watersurface profiles in areas where the 2005-06 DoD otherwise showed little re-working of the channel was interpreted as the discharge-related component of water-surface elevation change, and this value was used as an appropriate watersurface offset relative to the 2013 lidar.

The 2006 DEM is based on a relatively sparse lidar dataset with low point densities. As a result, bare-earth topography below vegetation typically involved significant interpolation, and it is likely that low vegetation points were often incorrectly classified as ground points. A comparison of stable areas in the 2006 and higher-quality 2005 survey indicated that the 2006 data was systematically biased high relative to the 2005 data, and that the magnitude of that bias increased systematically with mean vegetation height (fig. 3). This relation was then used to correct mean elevations in
Table 3. Corrections applied to lidar, Nooksack River, northwestern Washington, 2005 and 2006.

[Stage: Study site and river mile markers shown in figures 1 and 2. All offsets shown in feet. Stage offsets were only applied to the wetted channel area Abbreviations: $\mathrm{ft}$, foot; lidar, light detection and ranging; NA, not applicable; $\mathrm{RM}$, river mile; $\times$, multiplied by]

\begin{tabular}{|c|c|c|c|}
\hline \multirow[b]{2}{*}{ Location } & \multicolumn{3}{|r|}{ Offset } \\
\hline & $\begin{array}{c}\text { Vertical } \\
\text { coregistration }\end{array}$ & Stage & $\begin{array}{l}\text { Vegetation-dependent } \\
\text { bias correction }\end{array}$ \\
\hline \multicolumn{4}{|c|}{ Offsets applied to 2005 lidar } \\
\hline RM 33.4-52 & -0.10 & 1.00 & NA \\
\hline \multicolumn{4}{|c|}{ Offsets applied to 2006 lidar } \\
\hline RM 18.9-26.5 & -0.42 & -0.50 & $-0.014 \times$ veg_height_ft -0.24 \\
\hline RM 26.5-32.4 & 0.13 & & \\
\hline RM 32.4-41.7 & 0.29 & & \\
\hline
\end{tabular}

the 2006 lidar and to reduce positive bias in that dataset. A comparison of estimated volumetric change based on 2005-13 and 2006-13 in overlap indicates that the applied corrections improve agreement between the two datasets (fig. 4). More broadly, these corrections were generally modest in scale when compared to mean change at individual $650 \mathrm{ft}$ reaches, and the raw and corrected data provide similar results in terms of the qualitative sense of where the river was aggrading or incising. However, as the area of analysis increases, aggrading and incising reaches tend to offset each other, and the mean vertical change was typically small. As a result, estimates of total mean change over large areas were sensitive to the applied corrections.

Differencing was performed between the 2005 and 2013 lidar upstream of RM 33 (the South Fork Confluence), and between the 2006 and 2013 lidar downstream of that point. Given the limited geomorphic change observed between 2005 and 2006 in areas of overlap (fig. 3), 2005-13 change from RM 52 to 33 was combined with 2006-13 change from RM 33 to 19 to create a spatially continuous record over an approximately consistent epoch. All volumetric and mean changes were calculated over regular polygons spanning the width of the geomorphically active channel, and covering $650 \mathrm{ft}$ along the valley centerline. The geomorphically active channel was defined as the maximum lateral extent over which geomorphic change associated with river processes was observed during 2005/06-2013. 


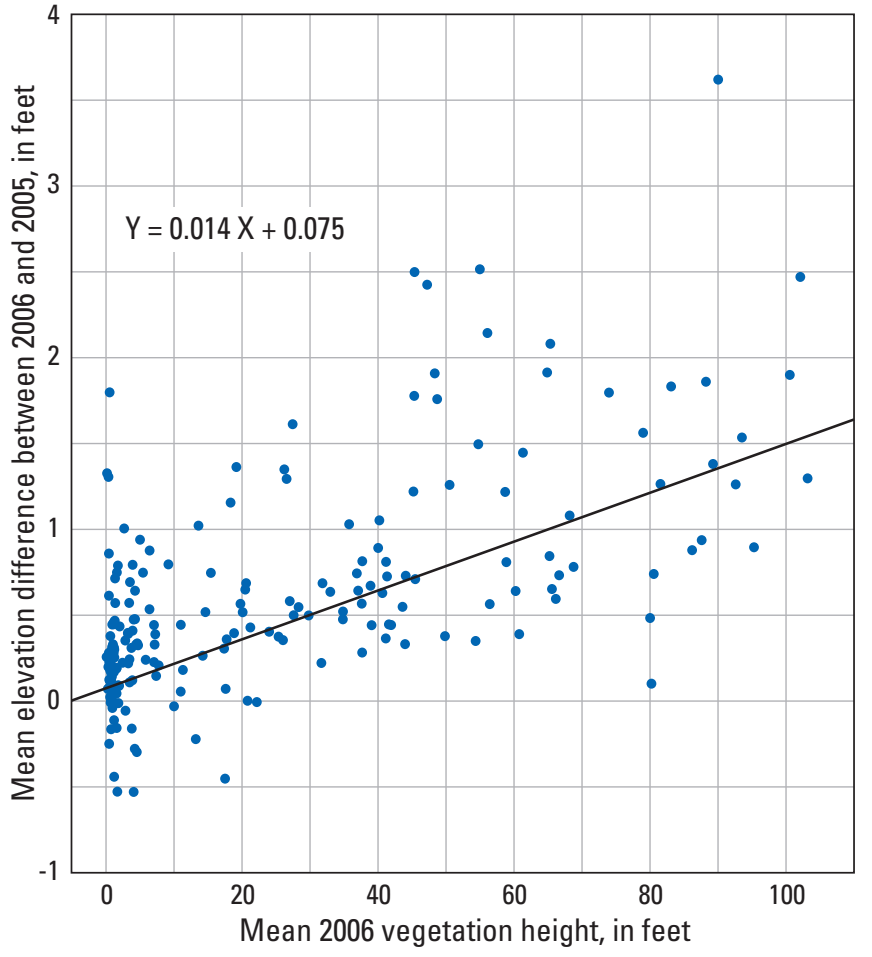

\section{Uncertainty In Topographic Differencing}

Calculations of net change over large areas are sensitive to small, systematic errors (bias) (Grams and others, 2013; Anderson and Pitlick, 2014; Gauemann and others, 2017). Potential sources of systematic error include vertical co-registration errors, stage-related water surface elevation differences, and, in the case of the 2006-13 differencing, the vegetation-related vertical bias. Although corrections for these various sources of systematic error were applied, those corrections are necessarily imperfect and some amount of systematic or mean error is still present. Uncertainty around the vertical co-registration was estimated to be $\pm 0.15 \mathrm{ft}$, based on the spread of residual errors on road surfaces after correction; uncertainty in the vegetation-based correction was estimated at $\pm 0.5 \mathrm{ft}$ based on uncertainty around the regression, and was applicable over the 70 percent of the analysis area with some vegetation. Uncertainty in the discharge-dependent stage correction was estimated at \pm 0.25 $\mathrm{ft}$, applicable over the 30 percent of the analysis area that was wetted. These uncertainties were assumed to be independent and combined in quadrature to estimate the combined uncertainty,

Figure 3. Bias in 2006 lidar as a function of mean vegetation height, Nooksack River, northwestern Washington. Lidar data were subdivided by first delineating areas of approximately consistent vegetation cover, and then splitting those vegetation class polygons at 650 -foot long intervals as measured along the valley centerline.

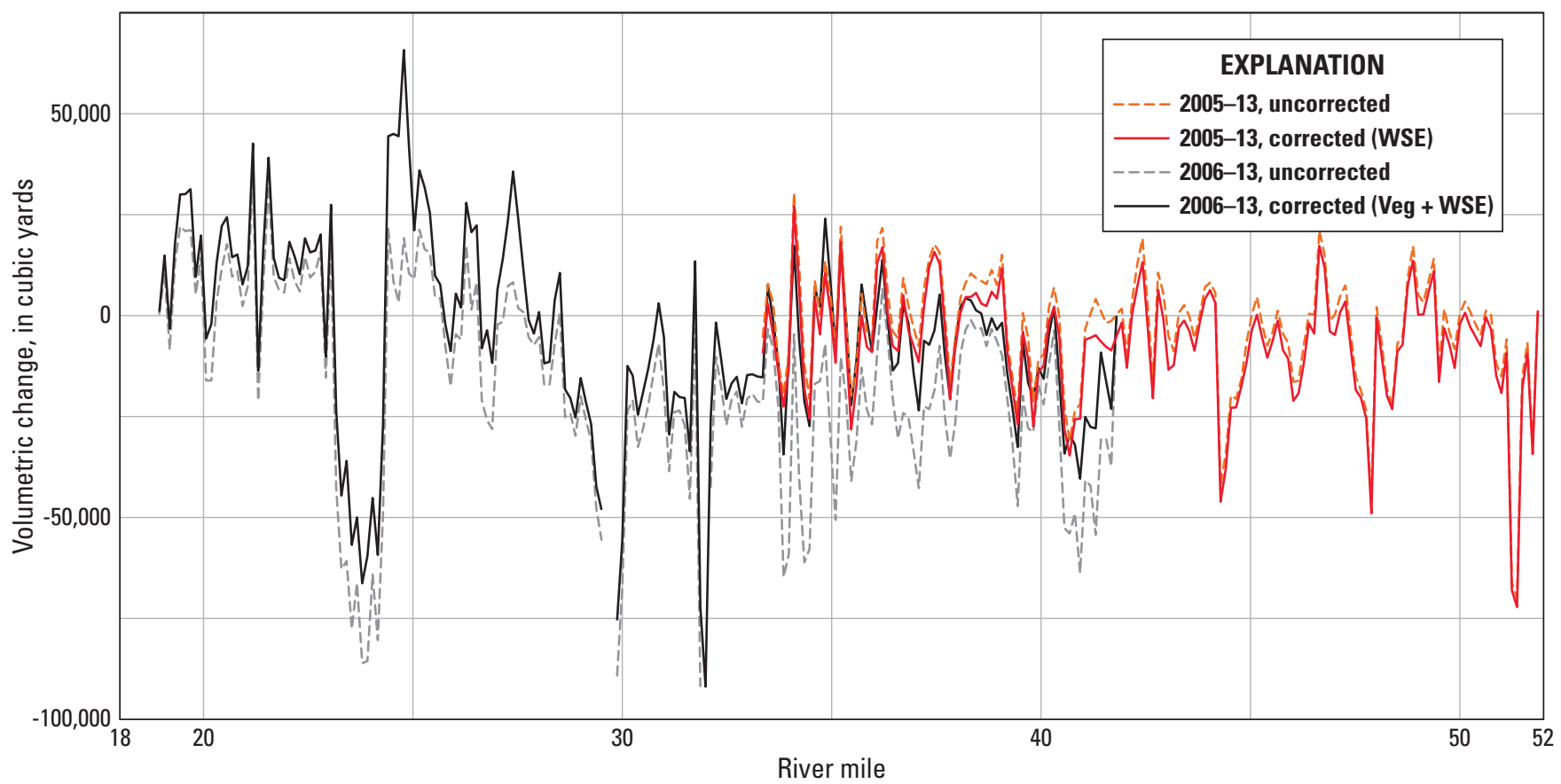

Figure 4. Raw and corrected volumetric change estimates based on repeat aerial lidar by river mile, Nooksack River, northwestern Washington, 2005-13 


$$
\sigma_{\text {total }}=\sqrt{0.15^{2}+(0.7 \times 0.5)^{2}+(0.3 \times 0.25)^{2}}=0.38 \mathrm{ft}
$$

which was rounded to $\pm 0.40 \mathrm{ft}$ and taken to be the 95 percent uncertainty range. This value represents the uncertainty in estimates of mean elevation change over moderate to large areas, and not the precision of individual DoD measurement points. Volumetric uncertainty over an area is given by multiplying this mean uncertainty by the area of analysis.

\section{Cross-Section Differencing}

A set of 316 cross-sections were surveyed in 2006 by U.S. Army Corps of Engineers for Whatcom County from RM 28 down the mainstem Nooksack to RM 0. The 2006 cross-sections were compared against cross-sections cut from continuous topography collected for this study in 2015. The 2015 topographic data was created through the combination of 2015 bathymetric and structure from motion (SfM) surveys, which provided elevations for the submerged channel and bare-gravel areas, respectively (Anderson and Grossman, 2017). In that 2015 dataset, kriging interpolation methods were used to create continuous a continuous bathymetric surface from the original 2015 bathymetric points. The 2013 lidar was used to fill in heavily vegetated or overbank areas, which are not represented in SfM surveys, as well as exposed gravel below RM 19, which was beyond the extent of the 2015 SfM survey. In locations where the 2015 active channel had migrated beyond the extents of the 2006 cross-sections, those 2006 cross-sections were extended using the 2006 lidar. The mean elevation of channel cross-section was calculated by summing the area under the cross-section above zero elevation over the total width of the active channel, and then dividing that area by the cross-section width.

A limitation in this analysis is the horizontal resolution of the 2015 bathymetry from RM 6.5 (upstream of Ferndale) to about RM 20. Over that extent, the continuous bathymetric surface was interpolated based on relatively sparse bathymetric survey points that often missed the thalweg. The interpolated bed surface often indicated relatively shallow or shallowing channel depths near un-surveyed edges of the channel, where the broader geometry of the 2015 cross-section and the 2006 cross-sections both suggested the channel should be deepest. Upstream of RM 20, the potential error introduced by missing the thalweg was considered small relative to total channel change, given the broad expanses of bare gravel and active bank erosion. Over that extent, measured mean vertical change was accepted as reasonably accurate. Between RM 6.5 and 20, where the channel is tightly confined and there was little change in the general planform character, the
2015 bathymetry does not consistently include the thalweg, which results in an upward bias in the mean elevation of cross-sections. In this reach, mean elevations were only calculated over the bare-gravel extents and portions of the wetted cross-sections well-characterized by 2015 bathymetric measurements, and excluded poorly surveyed areas of the wetted channel. These truncated measures are considered highly uncertain and are interpreted more as qualitative measures of whether significant change had occurred in a cross section. Downstream of RM 6.5 near Ferndale, the bathymetric surface is based on a dense set of surveyed points, and the change results are again based on change over the full cross-section.

\section{Longitudinal Changes in Mean Elevation}

The combined results of DEM and cross-section differencing indicate that the Nooksack River from 2005/06 to 2013/15 was either stable or net erosional (overall lowering of the geomorphically active area) upstream of RM 28 , and either stable or net depositional (overall increase in the mean active-channel elevation) downstream of RM 28 (fig. 5). An exception from this general pattern occurred near RM 23, in the unconfined reach immediately upstream of Everson, which was net erosional between 2006 and 2013. Localized aggradation of about 1-2 ft occurred at Everson and just downstream of Ferndale. Significant net lowering at RM 30 is partially a product of net lowering associated with the 2014 Clay Banks landslide, though the reach was still net incisional after excluding that hillslope failure from the net change calculation. At the scale of individual $650 \mathrm{ft}$ reaches or individual cross-sections, the absolute magnitude of mean elevation change was almost everywhere less than $2 \mathrm{ft}$, and most commonly less than 1 foot.

Changes in water-surface elevation based on repeat lidar were noisy but broadly showed similar spatial patterns as mean elevation changes over the entire active channel. Given that the wetted channel only represented a small fraction of the geomorphically active valley floor in these surveys, this correspondence between water-surface change and total active channel sediment storage change is not a given. The agreement between the two metrics of change generally suggests that changes in elevation of the low-flow channel cause a re-grading of active-channel and floodplain deposits to a consistent level above that channel, with older surfaces formed at periods of higher or lower channel elevation being eroded away and replaced with deposits graded to the more recent channel elevation. 

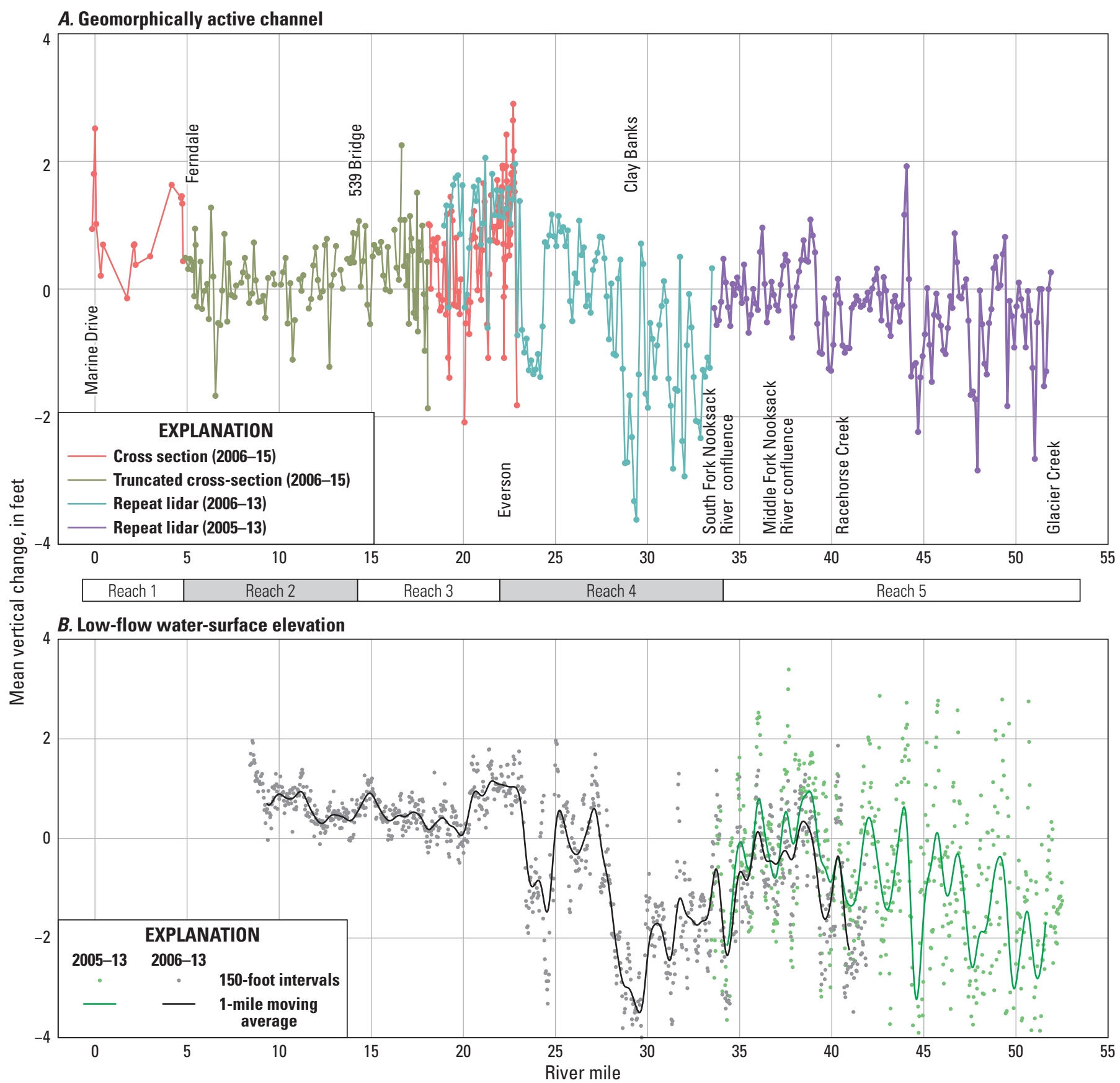

Figure 5. Mean vertical change in elevation in the Nooksack River, northwestern Washington, 2005-15. (A) Changes in mean elevation of the geomeorphically active channel. The geomorphically active channel width was defined as the maximum lateral extents over which geomorphic change plausibly related to river processes was observed in the 2005/06-13 digital elevation models of difference or repeat cross sections; mean vertical changes larger than 0.40 feet are considered statistically significant. $(B)$ Changes in the mean elevation of the low-flow water-surface elevation. Differences in water-surface elevation due to differences in discharge were approximately corrected based on stage-discharge relations recorded at streamgages in the study reach (2005-13) or observation of a systematic water-surface elevations offset in otherwise stable areas (2006-13). 


\section{Volumetric Change in Sediment Storage}

Volumetric change from 2005/6 to 2013 between RM 19 and 52 was visualized by cumulatively adding the net change in each $650 \mathrm{ft}$ segment, starting at the upstream-most segment and moving downstream (fig. 6). When viewed from right to left (the downstream direction), reaches where the cumulative net change was consistently increasing, decreasing, or remaining stable indicate spatially-continuous reaches of net deposition, erosion, or stability, respectively. The total volumetric net change over any given reach is given by the difference between the cumulative net change at the downstream and upstream boundaries of that reach.

The measured net volumetric change over the geomorphically active valley floor from RM 52 to 13 was $-1.7 \pm 2.5$ million $\mathrm{yd}^{3}$ (fig. 6 ). This corresponds to a mean net elevation change of $-0.28 \pm 0.40 \mathrm{ft}$. This result is then indistinguishable from zero within uncertainty but largely excludes the possibility of a significant net increase in storage over the sum of reaches 3,4 , and 5 . About 0.6 million $\mathrm{yd}^{3}$ of the 1.7 million $\mathrm{yd}^{3}$ of net erosion was associated with hillslope failures that were fully captured in the lidar and delivered material directly to the channel, including several small to moderate hillslope failures in the North Fork (primarily upper reach 5), and the Clay Banks landslide at RM 30.

Based on the cumulative downstream net changes observed, the river can be divided into six reaches in which, despite local complexity, the average rate of volumetric change (average net erosion or deposition per river mile, as indicated by the slope of cumulative net change) was relatively uniform (fig. 6). Reaches were generally incising or stable upstream of RM 28 at Nugent's Corner and aggrading downstream, except for an incising reach from RM 24.5 to 22.8 just upstream of Everson. Distinct transitions between reaches with different bed elevation trends at RM 23, 28, 33, and 39 coincide with short, highly confined reaches (fig. 6B). The transition at RM 33 also coincides with the confluence of the South Fork Nooksack. The hydraulics of these various constrictions may then control the short-term spatial patterns of where sediment preferentially erodes or deposits. The abrupt transition from an aggrading to an incising reach at RM 24.5 occurs in a wide reach and appears to correspond to the onset of significant bank erosion, focused along the river left side of the channel (fig. 7).

\section{Channel as a Source of Sediment Load}

From 2006 to 2013, the active channel from RM 28 to 52 was net-incisional and acted as a source of sediment for downstream reaches (figs. 8 and 9). Over 8 years, total

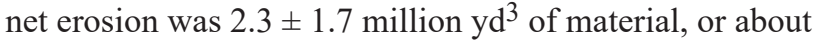
$290,000 \pm 220,000 \mathrm{yd}^{3} / \mathrm{yr}$ (table 4). Since no gravel extraction occurred over this period, mass balance implies that the net loss of sediment in the reach must have exited through the downstream boundary of the reach. The net erosion then provides a minimum estimate of the volumetric sediment flux past RM 28 near Nugent's Corner. Since the volume represents exchanges of sediment from the geomorphically active channel and immediately adjacent floodplain, it is reasonable to assume that a meaningful fraction of that sediment is material that would move as bedload. Using a range of possible bulk densities (Bunte and Abt, 2001, table 2.16), estimates of what fraction of that volume represented coarser material likely to move as bedload (0.4-0.8, estimated from field reconnaissance), and the uncertainty range of the volumetric change, between 35,000 to 650,000 tons/yr of coarse bed material was supplied to downstream reaches as a result of net incision upstream of RM 28 (table 5). Since this range of values only accounts for material sourced from net erosion in the lower North Fork Nooksack and upper mainstem Nooksack channel bed and does not include inputs from either the Middle or South Fork Nooksack or throughput bedload, these estimates are minimum bedload transport values. 

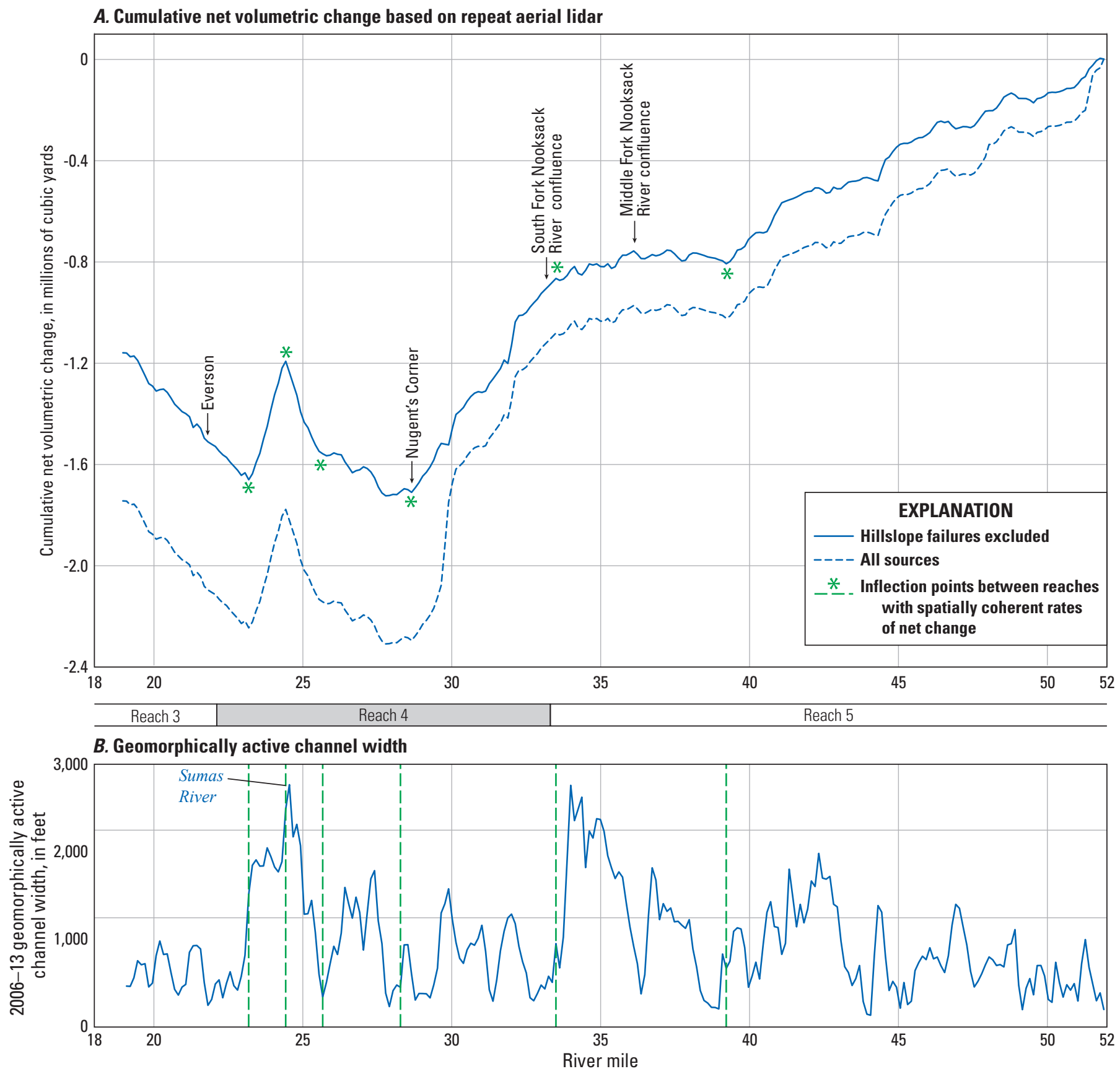

Figure 6. Cumulative net volumetric change based on repeat aerial lidar $(A)$ and geomorphically active channel width $(B)$, Nooksack River basin, northwestern Washington, 2005/06-13. Uncertainty around the cumulative net change grows linearly with increasing area and reaches $+/-2.5$ million cubic yards over the entire area of interest. Width is defined based on the maximum lateral extents of geomorphic change associated with river processes between the two lidar surveys. 


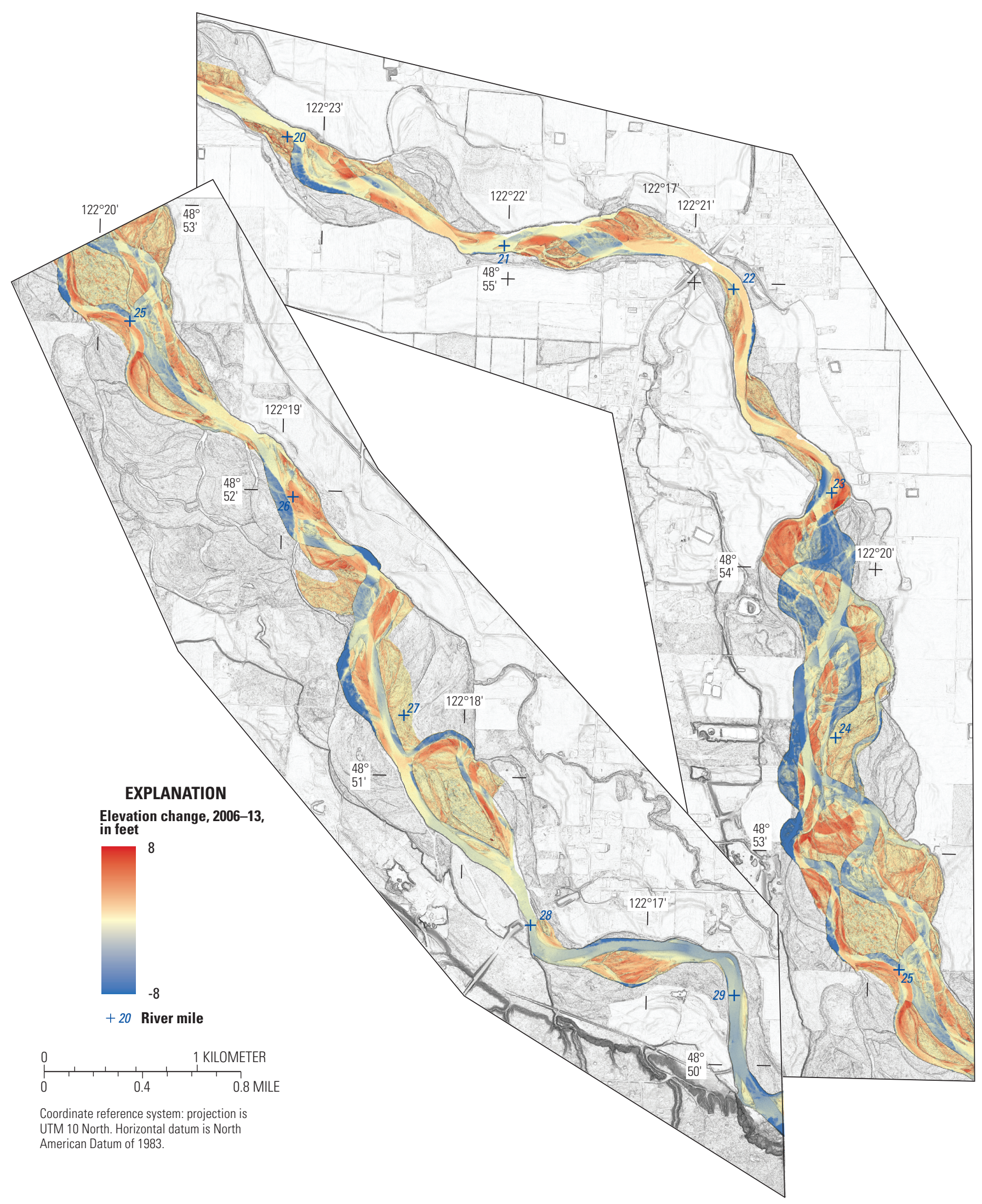

Figure 7. Digital elevation model of topographic change from 2006 to 2013 , based on differencing of repeat aerial lidar, from river mile 20 to 29, Nooksack River, northwestern Washington, 2006-13. Direction of river flow is from higher-numbered river mile to lower-numbered. 


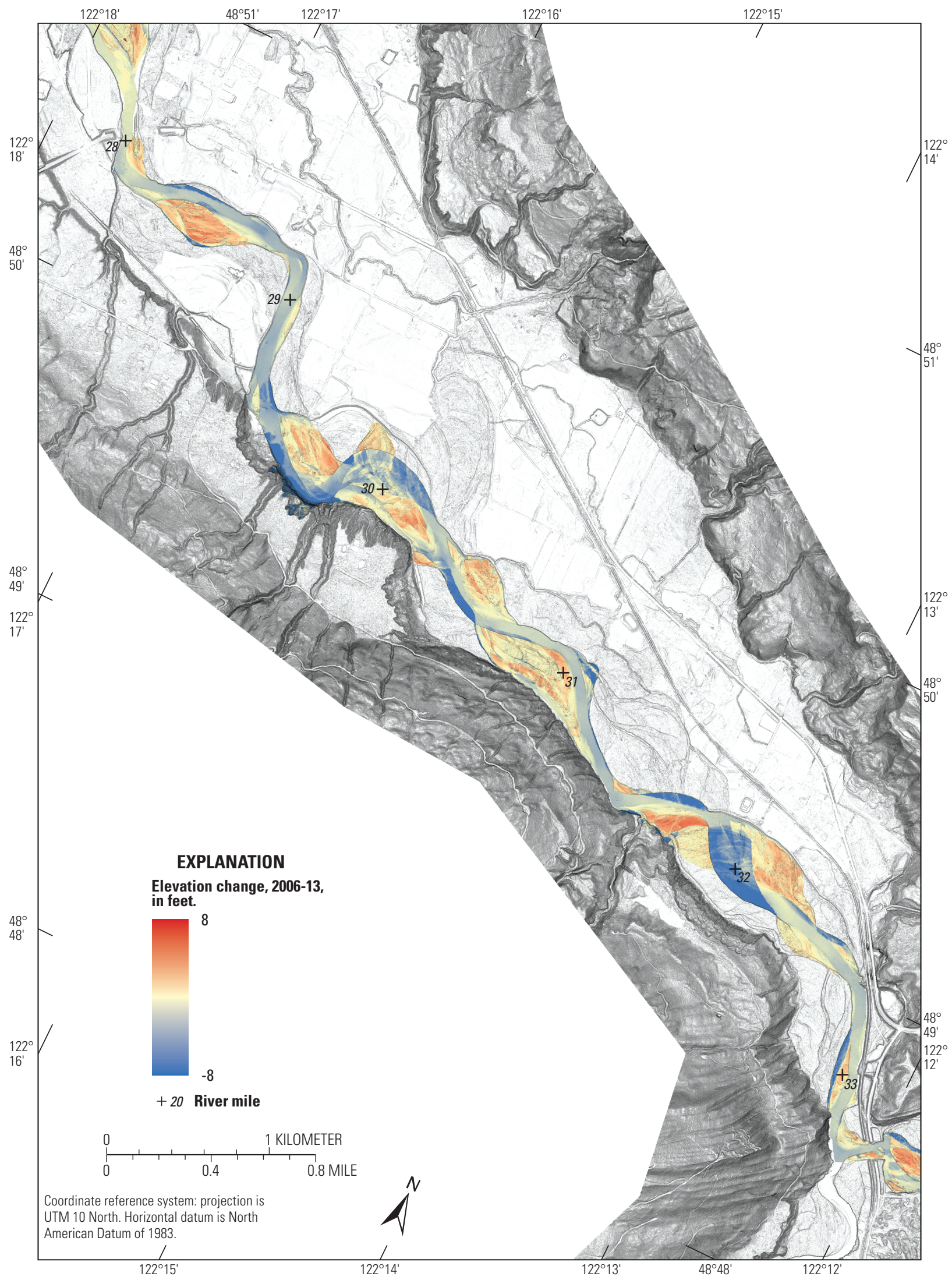

Figure 8. Digital elevation model of topographic change from 2006 to 2013, based on differencing of repeat aerial lidar, from river mile 28 to 33, Nooksack River, northwestern Washington, 2006-13. Direction of river flow is from higher-numbered river mile to lower-numbered. 


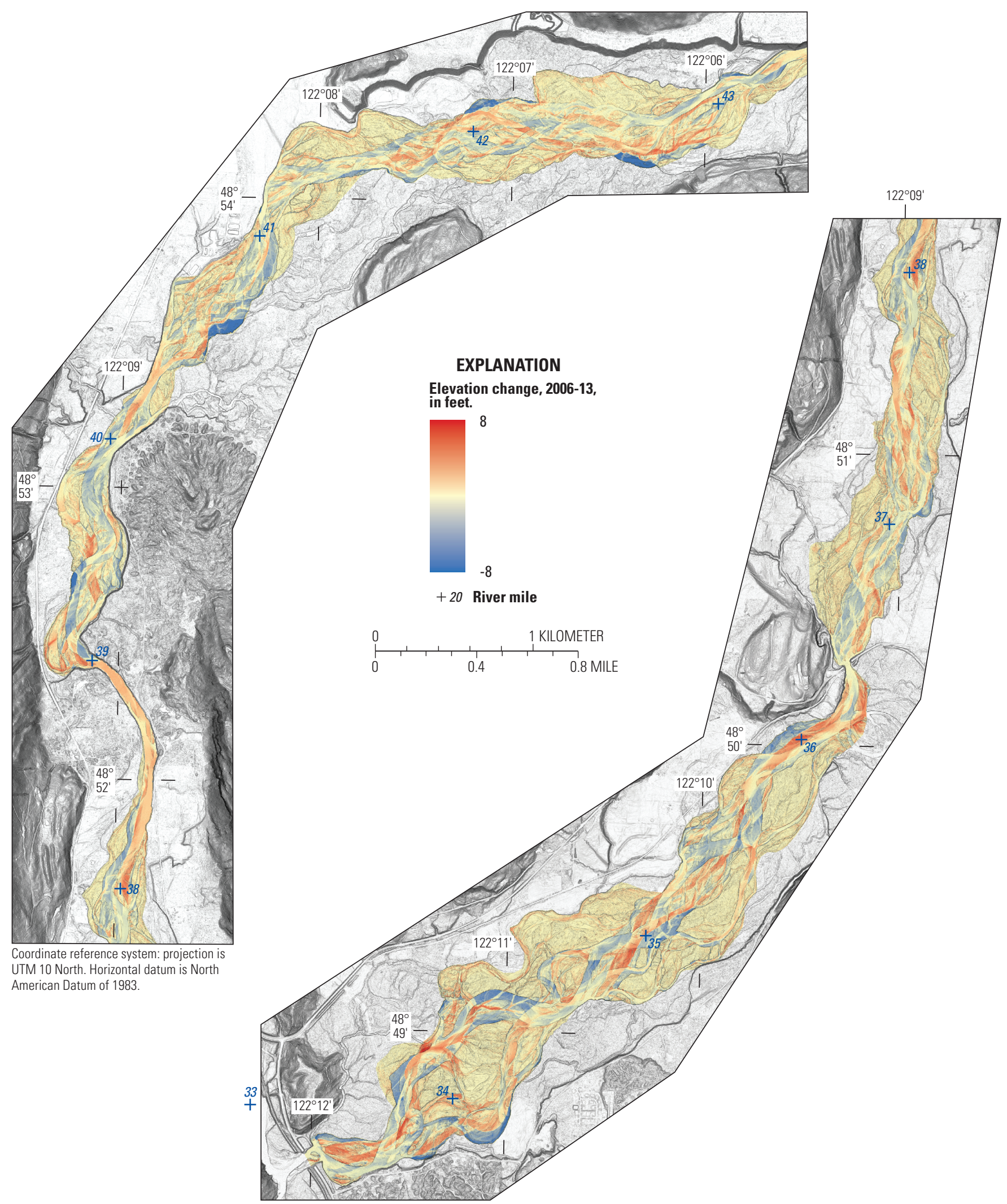

Figure 9. Digital elevation model of topographic change from 2005 to 2013 , based on differencing of repeat aerial lidar, from river mile 33 to 43 . Direction of river flow is from higher-numbered river mile to lower-numbered. 
Table 4. Volumetric change from 2005/06 to 2013 for various sub-reaches, Nooksack River, northwestern Washington, 2006-15.

[Abbreviations: $\mathrm{yd}^{3}$, cubic yard; ft, foot; RM, river mile; \pm , plus or minus]

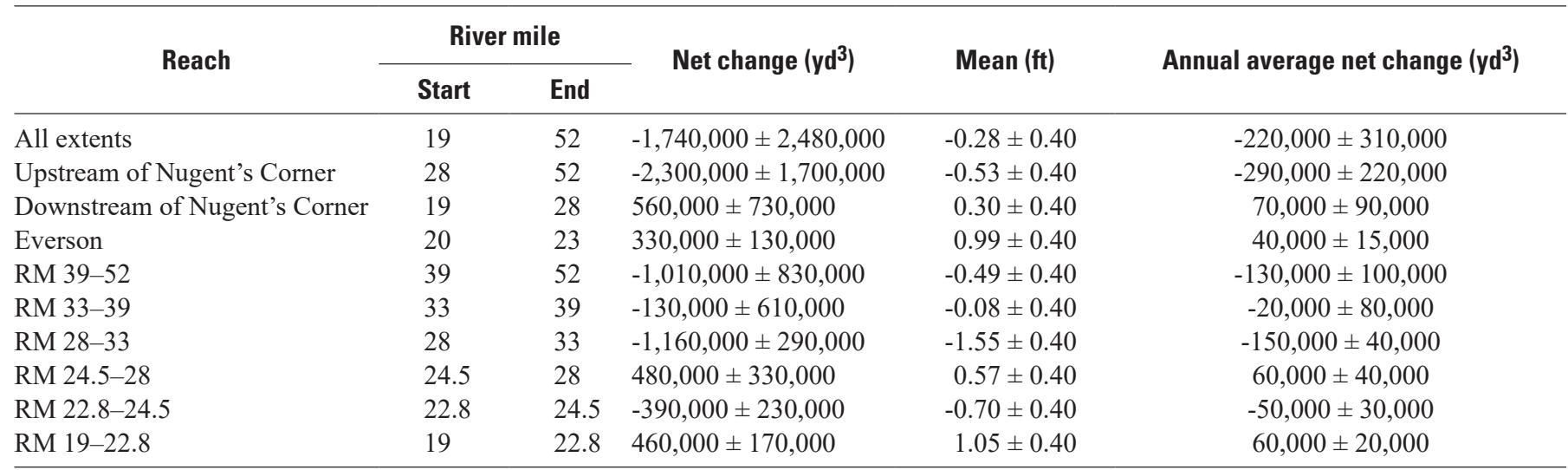

Table 5. Bed material supplied by net erosion of the channel upstream of Nugent's Corner, Nooksack River basin, northwestern Washington, 2006-15.

[Abbreviations: $\mathrm{yd}^{3} / \mathrm{yr}$, cubic yard per year; ton $/ \mathrm{yd}^{3}$, ton per cubic yard]

\begin{tabular}{lccc}
\hline & \multicolumn{3}{c}{ Subreach } \\
\cline { 2 - 4 } & Low & Central & High \\
\hline $\begin{array}{c}\text { Annual average net } \\
\text { erosion (yd } 3 \text { /yr) }\end{array}$ & 70,000 & 290,000 & 510,000 \\
$\begin{array}{c}\text { Bulk density (ton/yd }{ }^{3} \text { ) } \\
\text { Eroded mass (ton) }\end{array}$ & 1.2 & 1.4 & 1.6 \\
$\begin{array}{c}\text { Fraction of bed } \\
\text { material }\end{array}$ & 84,000 & 406,000 & 816,000 \\
$\begin{array}{c}\text { Eroded bed material } \\
\quad \text { ton) }\end{array}$ & 33,600 & 243,600 & 0.8 \\
$\begin{array}{c}\text { Eroded suspended } \\
\text { material (ton) }\end{array}$ & 50,400 & 162,400 & 163,200 \\
\hline
\end{tabular}

\section{Long-Term Trends in River Bed Elevation at U.S. Geological Survey Streamgages}

\section{Methods}

Historical measurements of stage and discharge at USGS streamflow-gaging stations can provide indications of changing channel conditions over the life of a given gage (James, 1991; Juracek and Fitzpatrick, 2009; Slater and others, 2015). Changes in the stage-discharge relation at 10 USGS streamgages in the basin (fig. 10; table 6) were assessed here by computing the differences (residual) between field measurements of stage taken during discharge measurements and the stage predicted from discharge using the most recently developed rating curve. At all gages, datum shifts or station moves were accounted for to ensure that all streamflow measurements referenced a common vertical datum. Positive residuals indicate that stage for the measured discharge was higher at the time of measurement than at present, while negative residuals indicate that stage was lower.

Changes in stage-discharge relation may occur due to changes in bed elevation, channel width, or hydraulic roughness. In contrast, depth-discharge relations are insensitive to changes in mean bed elevation and only respond to changes in width or roughness. Depth-discharge relations were evaluated to assess whether channel width and hydraulic roughness have varied over time. No systematic trends in depth-discharge relations were observed at any of the gages, indicating that observed stage-discharge trends were primarily a result of changing bed elevation.

The stage-residual method used here collapses information about stage-discharge shifts across the full range of measured discharges into a single time-series. If the slope of the rating curve has remained constant over time, the calculated stage-discharge residual should be insensitive to the measurement discharge, and the entire suite of measurements can be readily combined. In contrast, changes in the slope of the rating curve would result in divergent trends for different ranges of measurement discharges. The consistency of the rating curve slope was assessed by visually inspecting whether stage residuals showed diverging discharge-dependent trends. Changes in stage-discharge relations over time were observed to be independent of measurement discharge for measurements made at or below about 1.5 times the mean annual discharge at all streamgages assessed here. Final time-series of vertical channel change were created by sub-setting the measurements to only those made across this range of low to moderate flows. The long-term records of change then provide an indication of changes in the mean elevation of the wetted channel boundary at low to moderate discharges. 


\section{A. South Fork Nooksack River}

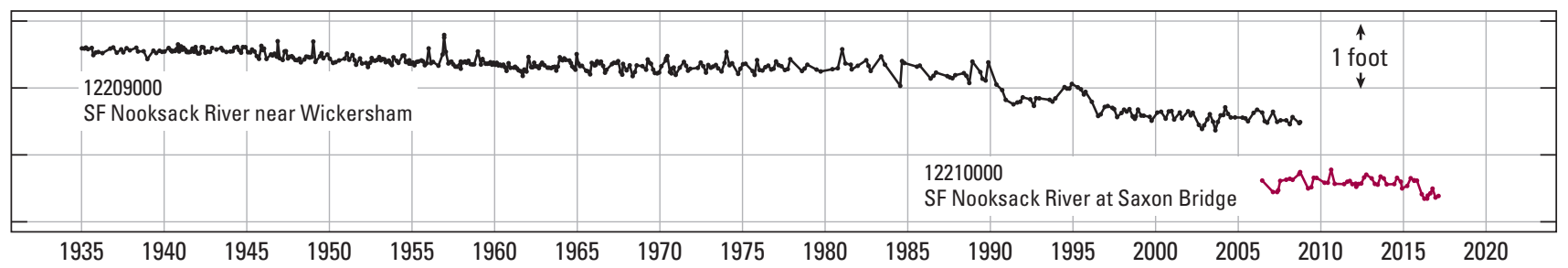

\section{B. Middle Fork Nooksack River}

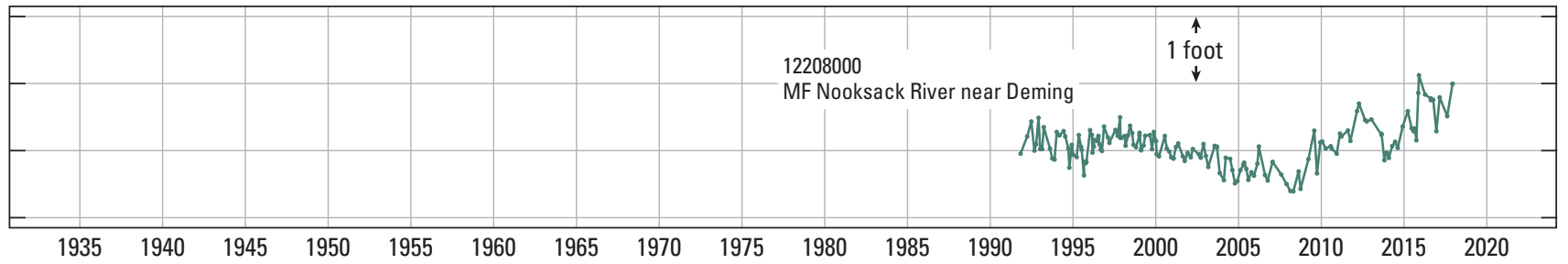

C. North Fork and mainstem Nooksack River

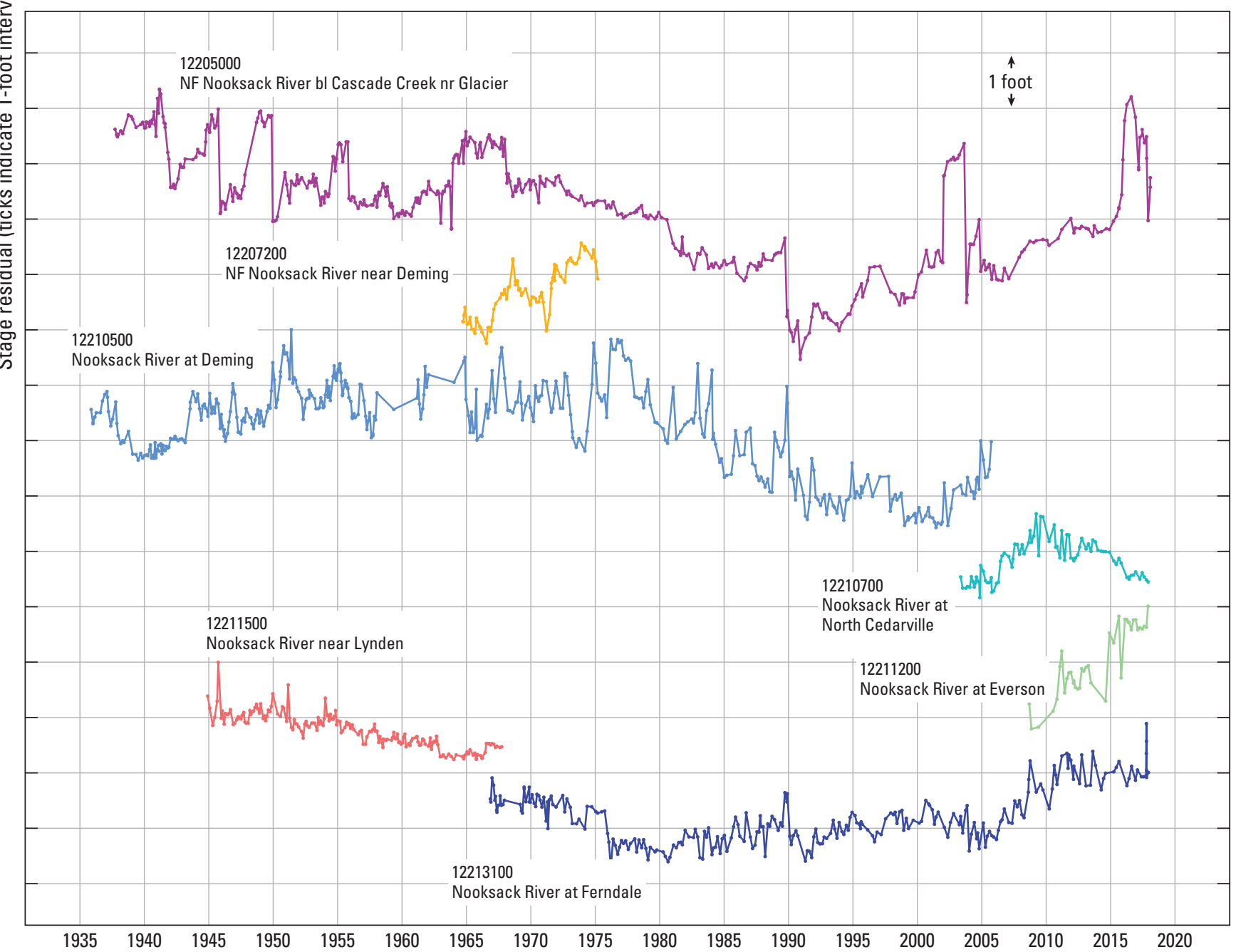

Figure 10. Changes in stage-discharge relations at all U.S. Geological Survey streamgages in the $(A)$ South Fork, $(B)$ Middle Fork, and $(C)$ North Fork and mainstem Nooksack River, northwestern Washington, 2005-15. Changes in stage-discharge are interpreted here primarily as an indication of changing channel bed elevations. Gages are separated by major basins and arranged from upstream to downstream order within a given basin. The absolute vertical positions of the various results are arbitrary and chosen for visual clarity. Locations of streamgages are shown in figure 1 and given in table 6. Results are based only on measurements made at less than 1.5 times the mean annual discharge at a given site, and so indicate changes only for the wetted cross-section at those low to moderate discharges. 
Table 6. Streamgages used in this report, Nooksack River basin, northwestern Washington, 2006-15.

[All streamgages are U.S. Geological Survey streamgages. River mile for streamgages on the Middle and South Fork Nooksack River are given as (river mile of confluence with North Fork or mainstem) plus (river miles upstream of confluence). Abbreviations: $\mathrm{ft}^{3} / \mathrm{s}$, cubic foot per second; $\mathrm{mi}^{2}$, square mile; $\mathrm{nr}$, near; WA, Washington]

\begin{tabular}{|c|c|c|c|c|c|c|}
\hline $\begin{array}{c}\text { Streamgage } \\
\text { No. }\end{array}$ & $\begin{array}{c}\text { Streamgage } \\
\text { name }\end{array}$ & River mile & $\begin{array}{l}\text { Drainage area } \\
\qquad\left(\mathrm{mi}^{2}\right)\end{array}$ & $\begin{array}{l}\text { Period of } \\
\text { record }\end{array}$ & $\begin{array}{c}\text { Mean annual } \\
\text { flow } \\
\left(\mathrm{ft}^{3} / \mathrm{s}\right)\end{array}$ & $\begin{array}{c}\text { 2-year flood } \\
\left(\mathrm{ft}^{3} / \mathrm{s}\right)\end{array}$ \\
\hline 12205000 & North Fork Nooksack nr Glacier, WA & 57.5 & 105 & 1938-present & 810 & 6,030 \\
\hline 12207200 & North Fork Nookack nr Deming, WA & 39.8 & 282 & $1964-75$ & 1,660 & 9,720 \\
\hline 12210500 & Nooksack River at Deming, WA & 33.2 & 584 & $1935-2005$ & 3,350 & 25,500 \\
\hline 12210700 & Nooksack River at North Cedarville, WA & 28.0 & 589 & 2003-present & 3,780 & - \\
\hline 12211200 & Nooksack River at Everson, WA & 21.9 & 628 & 2008-present & 3,950 & - \\
\hline 12211500 & Nooksack River nr Lynden, WA & 14.0 & 648 & $1944-67$ & 3,710 & - \\
\hline 12213100 & Nooksack River nr Ferndale, WA & 4.7 & 786 & 1966-present & 3,880 & 25,500 \\
\hline 12210000 & South Fork Nooksack at Saxon Bridge, WA & $33.3 / 10.1$ & 129 & 2008-present & 970 & - \\
\hline 12209000 & South Fork Nooksack nr Wickersham, WA & $33.3 / 11.9$ & 103 & $1933-2008$ & 748 & 10,000 \\
\hline 12208000 & Middle Fork Nooksack nr Deming, WA & $36.3 / 5.0$ & 74 & 1992-present & 529 & 6,070 \\
\hline
\end{tabular}

\section{Changes in Stage-Discharge Relations}

Changes in stage-discharge relations at the 10 streamgage sites indicate $1-3 \mathrm{ft}$ of variability in channel-bed elevations (fig. 10). Channel-beds at streamgage sites on the glacially influenced North Fork, Middle Fork, and mainstem Nooksack were generally more dynamic than channel-beds at the two sites on the South Fork Nooksack. From about 2000 to 2015, stage-residuals at Ferndale (12213100) and Everson (12211200) both indicate a 1-2 ft increase in mean channel elevation. Aggradation at Ferndale occurred from 2005 to 2010 and has since leveled off. Aggradation at Everson has occurred in two steps, one in 2011 and one in 2015. Stageresiduals at North Cedarville (12210700) and the upper North Fork (12205000) show 1-2 ft of variability, but minimal net change from 2000 to 2015 . However, there is a longer-term trend of aggradation in the upper North Fork, ongoing since 1990. All streamgages show periods of filling or scouring at relatively steady rates, on the order of $1 \mathrm{ft}$ per decade, that last several years to several decades.

Distinct periods of short-term filling and subsequent scour, lasting several years and with amplitudes of up to about $2 \mathrm{ft}$, have occurred frequently in the upper North Fork and, to a lesser degree, in the upper mainstem near Deming. These short-term pulses of aggradation are not apparent in the lower mainstem river. Most of the significant short-term adjustments in the upper North Fork can be attributed to individual large floods, though the timing and direction of change varies, and not all large floods caused significant change. For example, large fill events in 2002 and 2015 on the North Fork coincide with large floods in January 2002 (tenth-largest flood on record at that site) and December 2014 (third largest recorded flood), respectively. The 2002 pulse appears as a single step of aggradation between measurements bracketing the 2002 flood, then changed relatively little before recovering with a similarly abrupt step down between measurements bracketing the October 2003 flood, the largest in the period of record. The 2015 flood, in contrast, caused almost no immediate change, and the subsequent pulse shows a bell-shaped accumulation and removal of sediment that initiated several months after the flood and evolved smoothly over 2-3 years. In contrast to the significant channel responses experienced during the 2002, 2003, and 2015 floods, the second-largest flood on record occurred in November 2006 but was not associated with any significant channel response, immediate or delayed. The complexity of these flood responses most likely indicates that channel response to a given flood is strongly modulated by sediment availability and that flood magnitude alone is not a good predictor of the direction of channel adjustment.

\section{Downstream Propagation of Change}

The decadal-scale trends in the upper North Fork (12205000) are visually similar to the long-term trends in the upper mainstem near Deming (12210500) but offset by about 10 years (fig. 10). This downstream-lagged similarity suggested that channel change may propagate downstream. This possibility was formally assessed using cross-correlation analysis of bed-elevation change for each pair of streamgages, where the time series of bed-elevation change at one streamgage was progressively shifted relative to another in order to assess how correlation changed as a function of lag or lead times. For a given pair of streamgages, multiple correlation peaks were often present. However, there existed a set of lag and lead times that were both local peaks in the cross-correlation between any two streamgages and provides an internally coherent arrangement, in that the lag from gage $\mathrm{A}$ to $\mathrm{C}$ equaled the sum of the lags from $\mathrm{A}$ to $\mathrm{B}$ and $\mathrm{B}$ to $\mathrm{C}$ (table 7). Channel change at all seven streamgages on the North Fork and mainstem can then be explained as the downstream propagation of a single pattern of change (fig. 11). Patterns of change observed in the upper North Fork are then being repeated at downstream sites, but with an increasingly long lag time. That lag, relative to the upper North Fork gage site, was 10 years at Deming, 20 years at Everson, and about 45 years at Ferndale. 
Table 7. Cross-correlation analysis of stage-discharge changes at U.S. Geological Survey streamgages on the North Fork and mainstem Nooksack River, northwestern Washington, 2006-15.

[All streamgages shown are U.S. Geological Survey streamgages. Values in bold indicate lag times, in years, between a given base and shifted streamgage; italic values are Pearsons R for the correlation with that lag. Lag times were selected as the local cross-correlation maximum that provided the best internal coherence between all possible streamgage pairs and does not necessarily represent the global cross-correlation peak for any given streamgage pair]

\begin{tabular}{|c|c|c|c|c|c|c|}
\hline \multirow{2}{*}{$\begin{array}{c}\text { Shifted } \\
\text { streamgage } \\
\text { No. }\end{array}$} & \multicolumn{6}{|c|}{ Base streamgage No. } \\
\hline & 12205000 & 12207200 & 12210500 & 12210700 & 12211200 & 12211500 \\
\hline 12207200 & $\begin{array}{l}7 \\
0.8\end{array}$ & & & & & \\
\hline 12210500 & $\begin{array}{c}\mathbf{1 0 . 1} \\
0.87\end{array}$ & $\begin{array}{l}\mathbf{3 . 3} \\
0.74\end{array}$ & & & & \\
\hline 12210700 & $\begin{array}{c}\mathbf{1 3 . 6} \\
0.42\end{array}$ & $N A$ & $\begin{array}{l}\mathbf{4 . 1} \\
0.99\end{array}$ & & & \\
\hline 12211200 & $\begin{array}{c}\mathbf{1 8 . 8} \\
0.93\end{array}$ & $N A$ & $\begin{array}{l}\mathbf{6 . 4} \\
0.94\end{array}$ & $N A$ & & \\
\hline 12211500 & $N A$ & $N A$ & $\begin{array}{c}\mathbf{2 4 . 4} \\
0.96\end{array}$ & $N A$ & $N A$ & \\
\hline 12213100 & $\begin{array}{c}\mathbf{4 5 . 4} \\
0.02\end{array}$ & $\begin{array}{c}\mathbf{4 3 . 4} \\
0.94\end{array}$ & $\begin{array}{l}38 \\
0.49\end{array}$ & $N A$ & $N A$ & $\begin{array}{c}\mathbf{1 5 . 6} \\
0.93\end{array}$ \\
\hline
\end{tabular}

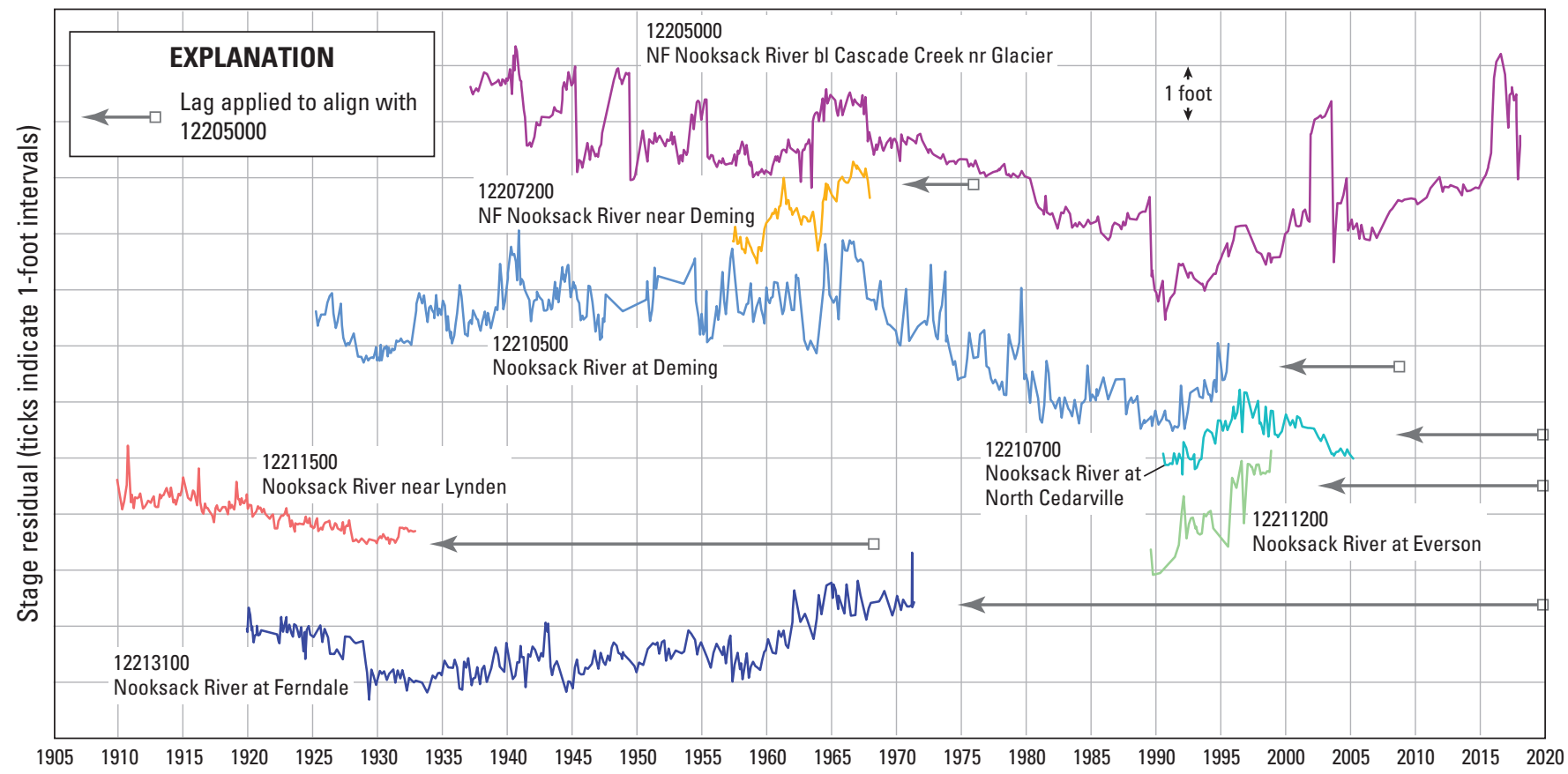

Figure 11. Changes in stage-discharge relations at all streamgages in the North Fork and mainstem Nooksack River, lagged to align with the upstream-most streamgage on the North Fork Nooksack River (12205000), northwestern Washington, 1938-2018. Lag times applied are based on cross-correlation analysis (table 7). 


\section{Bed Change Propagation Rates}

Dividing the lag or lead time between streamgages by the active-channel centerline distance between those streamgages gives the rate of travel of the bed change signal. That rate ranged from about 0.5 to $2.5 \mathrm{mi} / \mathrm{yr}$ (fig. 12, table 8 ). Propagation rates were generally highest in the upper basin and slowed moving downstream. Propagation rates were strongly related to mean channel slope, and the relation between the two was well-described as a power-law with an exponent of approximately 0.5 (rates of travel scale with the square root of channel slope). Since velocities average as harmonic means and not arithmetic means (that is, if 1 mile is traveled at $1 \mathrm{mi} / \mathrm{h}$ and a second mile is traveled at 2 miles per hour, the average velocity is 1.33 miles per hour, not 1.5), mean channel slopes between streamgages were also calculated as the harmonic mean. Comparison of average velocities to rise-over-run mean slope (effectively the arithmetic mean) introduces a small bias into the results due to the different averaging methods.

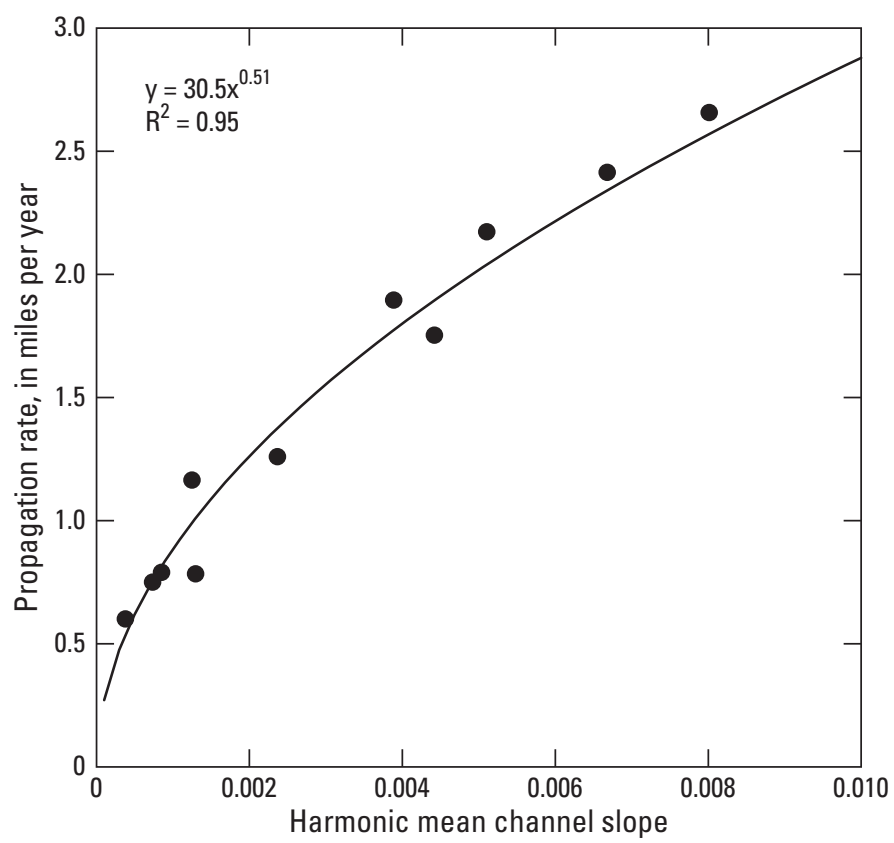

Figure 12. Propagation rate for bed-wave as a function of channel slope, Nooksack River basin, northwestern Washington. Propagation rates were calculated by dividing estimated lag times between streamgages by channel distances between changes for each streamgagepair with a statistically significant lagged correlation.
Observed Versus Estimated Vertical Change Based On Repeat Topography and Streamgage Analysis, 2006-13

Repeat topography from 2005/06 and 2013 and streamgage analyses provide two independent, comparable measures of vertical channel change. In addition to comparisons at the streamgage sites themselves, the observation of a consistent, propagating pattern of bed elevation change, moving at a slope-dependent rate of travel, allows for predictions of expected mean elevation change over the entire study area. Expected mean elevation change based on streamgage analyses were calculated by propagating the record of change seen in the upper North Fork at the observed slope-dependent rate of travel to provide expected relative elevation change from 2006 to 2013 at regular intervals.

Changes in bed elevation based on repeat topography closely match changes estimated from changing stagedischarge relations at individual gage sites (fig. 13). Spatially continuous estimates of expected vertical change, based on the concept of a downstream-propagating pattern of bed elevation change, show a mixed relation to change observed from repeat topography. Extrapolation of the streamgage records correctly predicts localized aggradation near Ferndale and Everson, bounded by a less active reach. However, upstream of Everson, where the river becomes generally unconfined, streamgage records would predict consistent aggradation, while observations from repeat topography show consistent incision. These results suggest that confined and unconfined reaches may respond differently to the passage of that wave.

\section{Relations Between Regional Climate and Propagated Pattern of Bed Change}

Long-term trends in channel elevation in the North Fork Nooksack River show decadal periods of persistent adjustment, marked by relatively abrupt transitions. The timing and extent of these shifts is similar to regional climate shifts (Mantua and others, 1997; Johnstone and Mantua, 2014). Regional climate was then evaluated as a potential control on these long-term periods of between aggradation and incision in the headwaters of the river. 
Table 8. Bed wave propagation rates for all valid streamgage pairs, Nooksack River basin, northwestern Washington, 2006-15.

[Abbreviations: mi, mile; mi/yr, mile per year]

\begin{tabular}{|c|c|c|c|c|c|c|}
\hline \multicolumn{2}{|c|}{$\begin{array}{c}\text { U.S. Geological Survey } \\
\text { streamgage No. }\end{array}$} & \multirow{2}{*}{$\begin{array}{l}\text { Lag time } \\
\text { (years) }\end{array}$} & \multirow{2}{*}{$\begin{array}{l}\text { Channel } \\
\text { distance } \\
\text { (mi) }\end{array}$} & \multirow{2}{*}{$\begin{array}{l}\text { Linear mean } \\
\text { channel } \\
\text { slope }\end{array}$} & \multirow{2}{*}{$\begin{array}{c}\text { Harmonic } \\
\text { mean } \\
\text { slope }\end{array}$} & \multirow{2}{*}{$\begin{array}{c}\text { Propagatior } \\
\text { rate } \\
\text { (mi/yr) }\end{array}$} \\
\hline Start & End & & & & & \\
\hline 12205000 & 12207200 & 7 & 18.6 & 0.009 & 0.008 & 2.7 \\
\hline 12205000 & 12210500 & 10.1 & 24.4 & 0.008 & 0.007 & 2.4 \\
\hline 12205000 & 12210700 & 13.6 & 29.6 & 0.007 & 0.005 & 2.2 \\
\hline 12205000 & 12211200 & 18.8 & 35.6 & 0.006 & 0.004 & 1.9 \\
\hline 12207200 & 12210500 & 3.3 & 5.8 & 0.004 & 0.004 & 1.8 \\
\hline 12210500 & 12210700 & 4.1 & 5.2 & 0.002 & 0.002 & 1.3 \\
\hline 12205000 & 12213100 & 45.4 & 52.9 & 0.004 & 0.001 & 1.2 \\
\hline 12207200 & 12213100 & 43.4 & 34.3 & 0.002 & 0.001 & 0.8 \\
\hline 12210500 & 12211500 & 24.4 & 19.1 & 0.002 & 0.001 & 0.8 \\
\hline 12210500 & 12213100 & 38 & 28.5 & 0.001 & 0.001 & 0.7 \\
\hline 12211500 & 12213100 & 15.6 & 9.4 & 0.000 & 0.000 & 0.6 \\
\hline
\end{tabular}

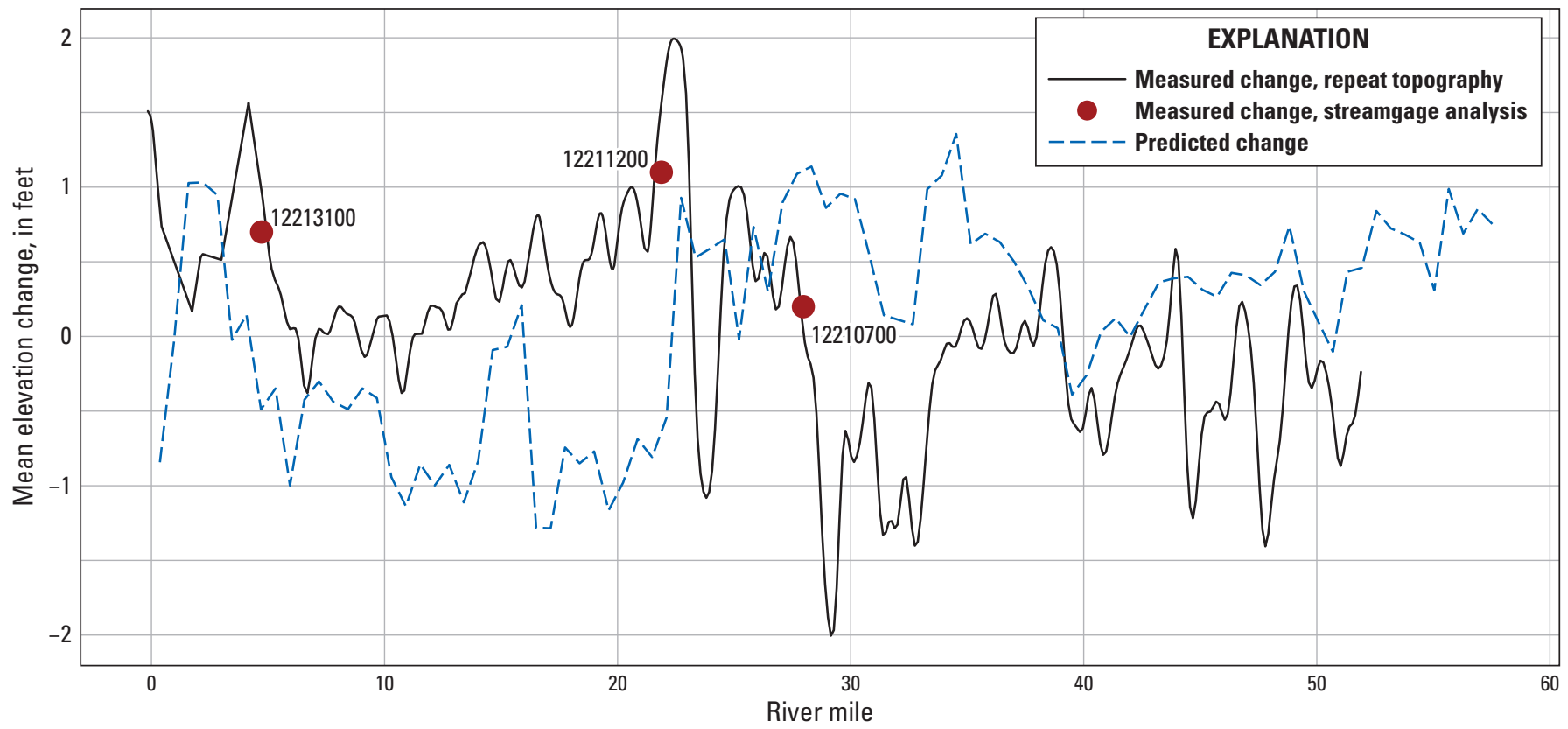

Figure 13. Comparison of measured bed-elevation change and forecasted bed-elevation change in the Nooksack River, northwestern Washington, 2005-06 to 2013-15. Spatially continuous forecasts of vertical change are based on the concept of a downstreampropagating bed wave and were obtained by taking the record of channel change at USGS streamgage 12205000 (fig. 10) and propagating it downstream at the slope-dependent rate shown in figure 12 to estimate relative bed-elevation change from 2006 to 2013. 


\section{Characterizing Regional Climate}

Broad trends in regional climate were characterized using a single climate index, modeled after the Pacific Northwest Index (PNI) presented by Ebbesmeyer and Strickland (1995). The original PNI index was based on mean annual temperature at a single station in Puget Sound, total precipitation at a different station in the western cascades, and April 15 snowpack at a station near Paradise on Mount Rainier. All records were first cast as standardized anomalies and the PNI was then calculated as the mean of the negative snowpack and precipitation anomalies and the positive temperature anomalies. The metric was most positive when it was relatively warm and precipitation and spring snowpacks were low, and most negative when it was relatively cool and precipitation and spring snowpack were high.

A climate index similar to the PNI was calculated using mean annual temperature and total annual precipitation data from NOAA's divisional climate data set (version 2; Vose and others, 2014), averaged over the western Cascade Mountains in Washington (Washington Climate Division 5; fig. 14). The NOAA dataset is a gridded (5 kilometer) product based on climatologically informed interpolation of historic station records, with records from 1895 to 2016 . The climate index was calculated by casting annual values in terms of standardized anomalies and then taking the average of the temperature anomaly and the negative precipitation anomaly, similar to the PNI but without snowpack data. The index is then most positive when the region is both warm and dry, and most negative when the region is both cool and wet. Note that "wet" and "dry" here refer only to total annual precipitation, and do not necessarily indicate periods of more or less intense flood activity. The climate index created here is strongly correlated with the original PNI (Pearson's R of 0.88), indicating that the measured climate trends are not sensitive to the exact location or derivation of the inputs. There is also a statistically significant correlation between our climate index and the Pacific decadal oscillation (PDO; fig. 14), indicating that the broad regional trends observed in the climate index are influenced by changes in sea surface conditions in the north Pacific.

\section{Regional Climate and Bed Elevation Trends}

When plotted as the cumulative departure from the mean, the shape of the climate index matches the composite shape of bed elevation trends in the upper North Fork Nooksack, but leads those bed changes by about 20 years (fig. 15). Periods of relatively warmer and/or drier regional conditions correspond to subsequent aggradation, while periods of relatively cooler and/or wetter regional conditions correspond to subsequent incision. Accounting for the lag between the various stations, the climate index can account for 35 to 50 percent of the variance in channel bed elevation at the three long-term gage sites $(12205000,12210500$, and 12213100). The consistent and statistically significant ( $\mathrm{p}<<0.001$ ) lagged correlation between climate and channel bed elevations over the entire 100 -year composite record of change suggests that regional climate has been an important control on decadal-scale trends in bed elevations at the gage sites analyzed here. Given the 20 -year lag between climate and change in the upper North Fork, and the 45-year lag between change in the upper North Fork and at Ferndale, the lag between a given climate shift and the subsequent bed response in the lower mainstem Nooksack River is about 65 years.

\section{Flood Stage Sensitivity to Channel Change}

The changes in the elevation based on streamgage records analyzed thus far indicate changes in stage-discharge relations at low to moderate discharges, which may not correspond directly to changes in stage at high-flow or flood discharges since flood discharge stages are influenced by floodplain roughness and the dynamic storage and release of water stored on those floodplains. To assess how changes in stage-discharge relations at low to moderate discharges relates to changes at higher discharges, stage residuals for measurements made above 20,000 cubic feet per second $\left(\mathrm{ft}^{3} / \mathrm{s}\right)$ were plotted against the concurrent stage residual from the low to moderate flow records at the mainstem steamgages near Ferndale and Deming (fig. 16). At both sites, there is a reasonable correspondence between the low-discharge stage residuals and high-discharge stage residuals up to about $25,000 \mathrm{ft}^{3} / \mathrm{s}$, approximately equal to the 0.5 annual exceedance discharge and often referred to as the 2-year flood. However, the $1-\mathrm{ft}$ increase in bed elevation that has occurred since 2005 at Ferndale does not appear to have caused a similar increase in the stage in the lone high-flow measurement made above $25,000 \mathrm{ft}^{3} / \mathrm{s}$.

All measurements made above about $30,000 \mathrm{ft}^{3} / \mathrm{s}$ at the Deming site were made over a short period from 1990 to 2005 when the bed was relatively stable, and so do not provide any test on whether those high-flow stages are responsive to channel elevation changes. These limited data suggest that changes in channel elevation may have direct influence on the stage of discharge at or near bankfull, and so would influence the frequency of such overbank events, but leave it unclear whether or not flood stages at discharges significantly above bankfull are responsive to observed bed elevation changes. 

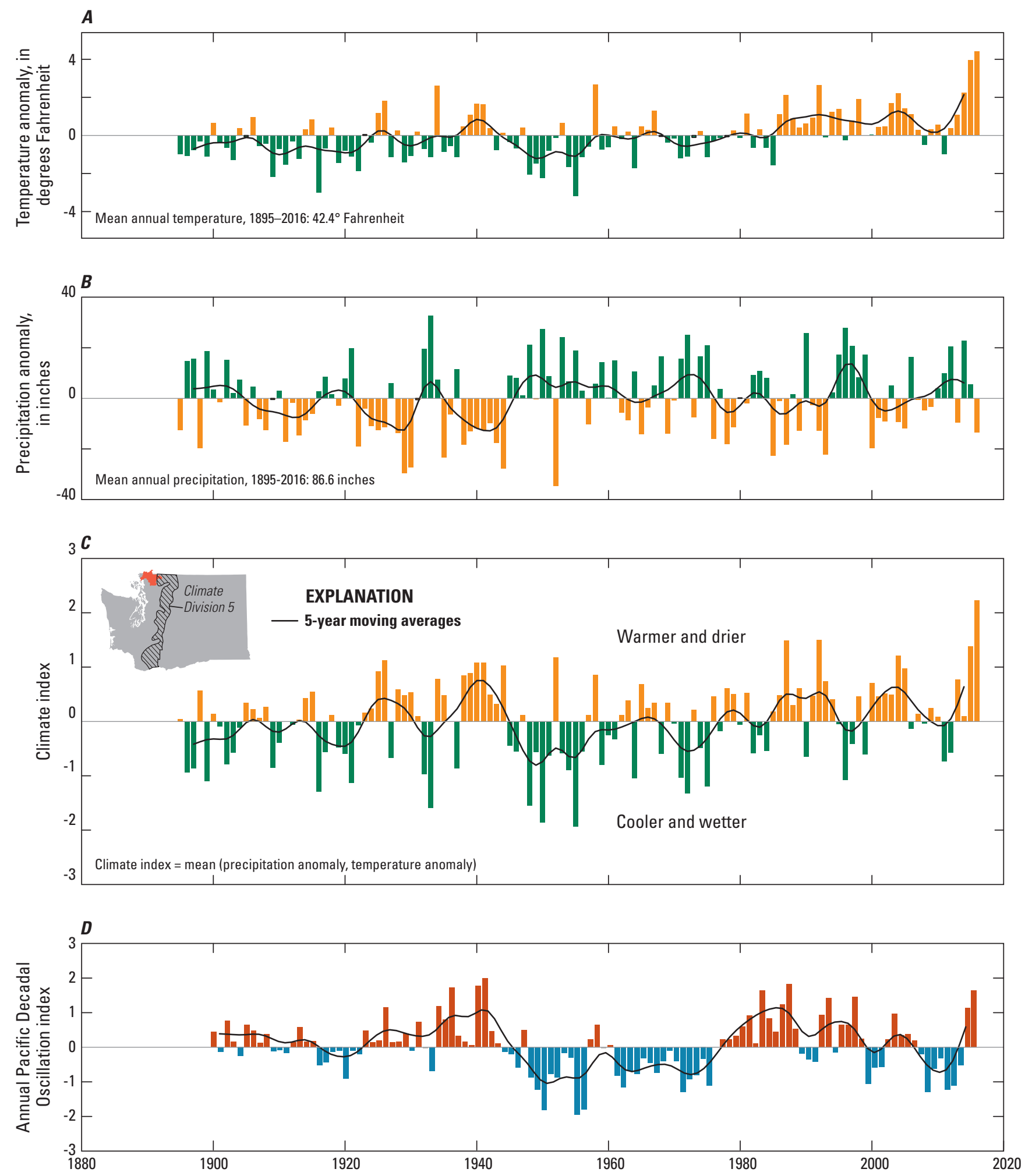

Figure 14. Regional climate index based on mean annual temperature and total precipitation, Nooksack River, northwestern Washington, 1895-2016. Temperature and precipitation data were obtained from Vose and others (2014) and averaged over Washington Climate Division 5, covering the western Cascade Mountains. $(A)$ annual mean temperaturerecords were centered by subtracting the period of record mean; $(B)$ annual precipitation records-records were centered by subtracting the period of record mean; $(C)$ derived climate index, calculated as the mean of the temperature anomaly and the negative of the precipitation anomaly in a given year-sub-plot shows the extent of climate division 5; (D) mean annual Pacific Decadal Oscillation index, obtained from Joint Institute for the Study of the Atmosphere and Ocean (2018). 

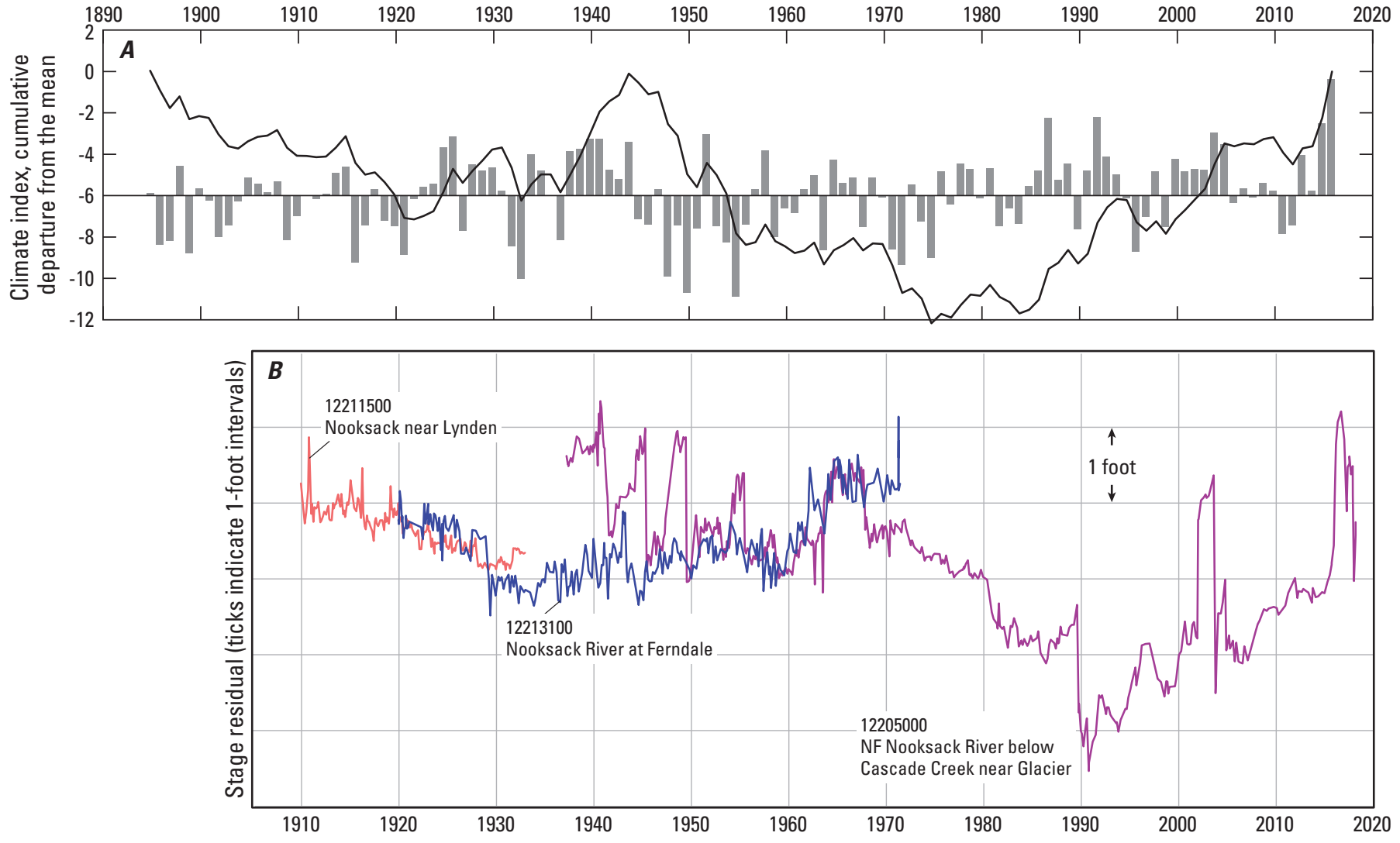

Figure 15. Changes in stage-discharge relations and regional climate index, Nooksack River, northwestern Washington, 1900-2018. (A) Regional climate index, plotted both as annual values and as the cumulative departure from the mean. When plotted as the cumulative departure, periods of generally cooler and (or) wetter climate app appear as periods with a persistent negative slope, while periods of generally warmer and (or) drier climate appear as periods of positive slope. (B) Changes in stage-discharge, lagged into alignment with the upstream-most North Fork streamgage. Only records for the upper North Fork, Ferndale, and Lynden streamgages are shown for clarity. 

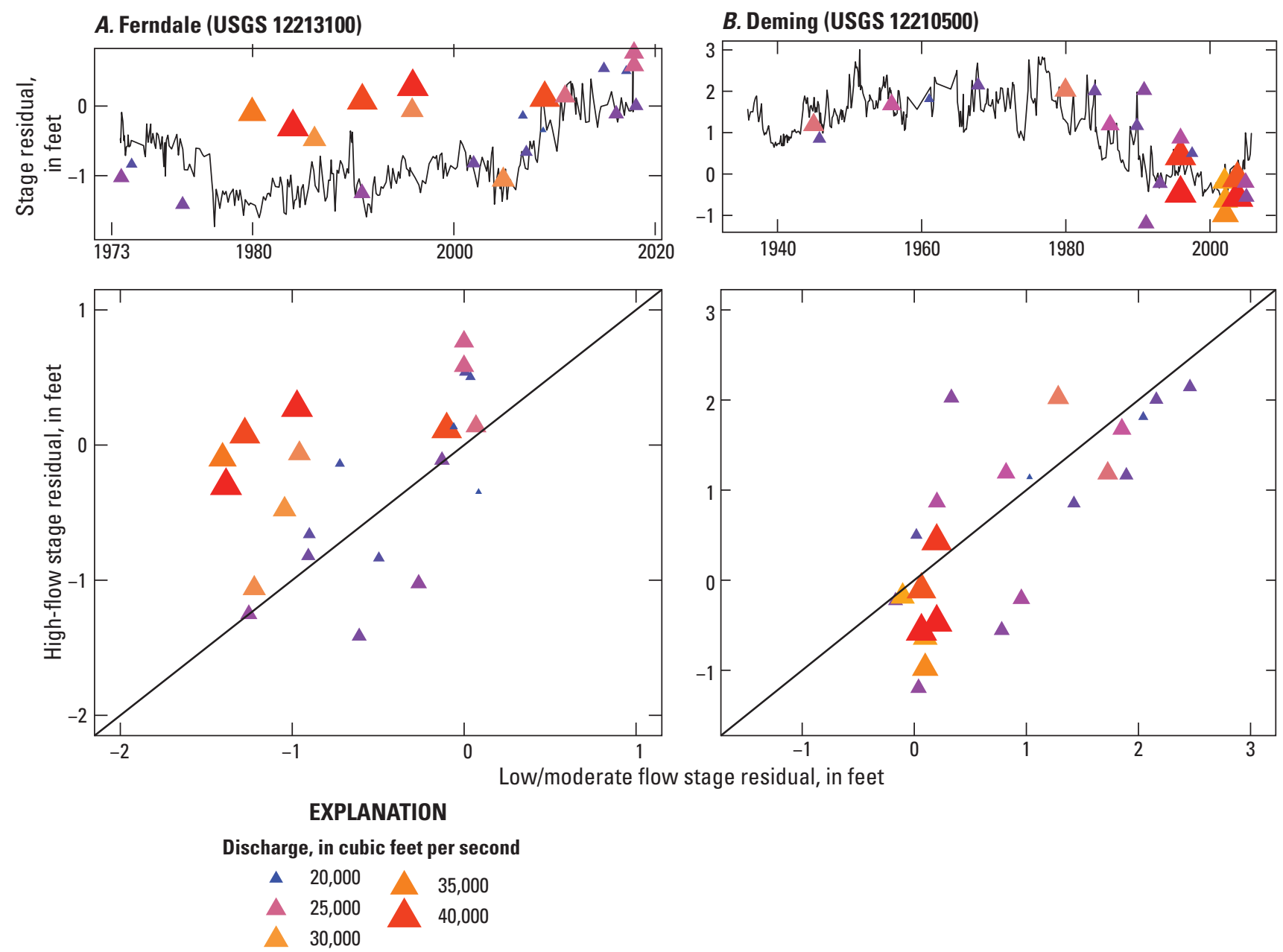

Figure 16. Relation between changes in stage-discharge relations at low to moderate discharges and concurrent changes in stage-discharge relations at high discharges at $(A)$ Nooksack River at Ferndale, Washington (U.S. Geological Survey streamgage 12213100) and (B) Nooksack River at Deming, Washington (U.S. Geological Survey streamgage 12210500), Nooksack River, northwestern Washington, 2005-15. Bankfull discharge at both sites is around 25,000 cubic feet per second.

\section{Fluvial Sediment Loads}

SSLs were estimated at five streamgage sites in the Nooksack Basin: the North Fork Nooksack River below Cascade Creek near Glacier, Washington (12205000), the Middle Fork Nooksack River near Deming, Washington (12208000), the South Fork Nooksack River at Saxon Bridge, Washington (12210000), Nooksack River at North Cedarville, Washington (12210700), and Nooksack River at Ferndale, Washington (12213100) (Curran and others, 2018; fig. 1). All sites were co-located with USGS streamgages, which provided concurrent records of discharge. Bedload sampling was performed at Ferndale and North Cedarville. However, only two measurements were successfully collected at Ferndale, and high velocities at North Cedarville resulted in no successful bedload sampling attempts. Bedload measurements at Ferndale were used to estimate the bedload to total load ratio, which was used to estimate the total sediment load at that site. At all other sites, sediment loads are discussed purely in terms of the finer fraction of the load moving in suspension.

\section{Calculating Suspended-Sediment Loads}

SSLs were estimated from continuous records of turbidity, sampled at either 15- or 60-minute intervals, which provides a surrogate for suspended-sediment concentrations (SSC). Turbidity-SSC relations were calibrated based on periodic measurements of cross-section mean SSC at each site, variously collected using equal-width increment (EWI) or equal-discharge increment (EDI) measurements. Additional point-SSC samples were collected at the North Fork site by hand and via an ISCO pump sampler at North Cedarville. All samples were analyzed by the Cascades Volcano Observatory (CVO) sediment lab for concentration; most, but not all, were also analyzed for the fraction of material finer than 0.063 millimeter (mm) (silt- or clay-sized particles). 
At each site, the relation between cross-section integrated SSC and turbidity was fit through ordinary leastsquares (OLS) regression, variously based on linear or log-transformed data. Only cross-section integrated EWI/ EDI samples were used for calibration of the final regression equations, excluding pump or grab samples. The resulting turbidity SSC rating curves were then used to transform the available turbidity records into continuous time-series estimates of SSC, which were then multiplied by the concurrent discharge to get SSL. Loads at 15-minute intervals were then summed to obtain daily and annual SSLs. Details of those regressions are available in Curran and others (2018).

All turbidity records included gaps of varying length, requiring some method of in-filling to provide complete daily and annual load estimates. Minor gaps in either 15-minute discharge or turbidity less than 3 hours long were filled using linear interpolation. For gaps longer than 3 hours, SSC was estimated at daily time scales, based on relations with daily mean discharge. At the non-glacial South Fork site, relations between discharge and measured SSC were well-defined and consistent over time. OLS regression on log-transformed variables was then used to create a discharge-SSC rating curve that, in combination with the turbidity SSC rating curve, provided a complete record of SSC and SSL for the South Fork. At the remaining four sites, relations between SSC and discharge were highly variable over both seasonal and annual time periods, reflecting the seasonal influence of glacial sediment inputs and inter-annual variability in sediment availability. For these four sites, daily mean SSC for days with missing turbidity records were estimated based on a timeinvariant, or baseline, SSC-discharge relation plus a timevarying residual component relative to that baseline (fig. 17). This model is based on the observation that residuals relative to that baseline regression were not random but instead varied systematically over time. Residuals for days with missing data were estimated through linear interpolation over the residuals immediately prior and immediately after the gap in the record. The daily mean SSC over that gap period was then predicted using the baseline regression, adjusted by the estimated residual. This method effectively assumes that the slope of the SSC-discharge rating curve is approximately constant, but that the intercept shifts up or down over time as a function of changing sediment availability. For days missing significant turbidity records, the appropriate amount of shift to apply to the baseline is estimated based on the shift observed prior to and following that missing period of record.

For each site, the baseline relation and residuals were assessed using daily mean SSC values calculated using all days with complete turbidity records. The baseline relations were defined using OLS regression on log-transformed values for all days in November-March, when SSC-discharge relations were well-defined (fig. 17). Residuals in log-space were calculated for each day with a complete turbidity record. Residuals for days without turbidity records were then estimated based on linear interpolation of the residual time-series for complete days. Daily mean SSC for those days with missing turbidity records were then estimated using the baseline regression plus the interpolated residual, and transformed into loads using concurrent daily mean discharge and an appropriate unitsconversion factor.

\section{Bedload Measurements}

Two bedload measurements were collected at Ferndale during the winter of WY 2017. The samples were collected using an Elwha bedload sampler with a rectangular opening of $4 \times 8$ inch (in.) and collection bag with a 0.02 in. (0.5 $\mathrm{mm})$ mesh size. Cross-section samples were collected at 7-8 verticals across the channel and composited for analysis. On a given sampling day, two to three complete cross-section samples were collected and analyzed separately, providing replicates to assess consistency. All cross-section composites were analyzed at the CVO sediment lab for total dry mass and whole-phi grain size distributions. Bedload sampling was attempted at North Cedarville, but was ultimately unsuccessful due to high water velocities. 

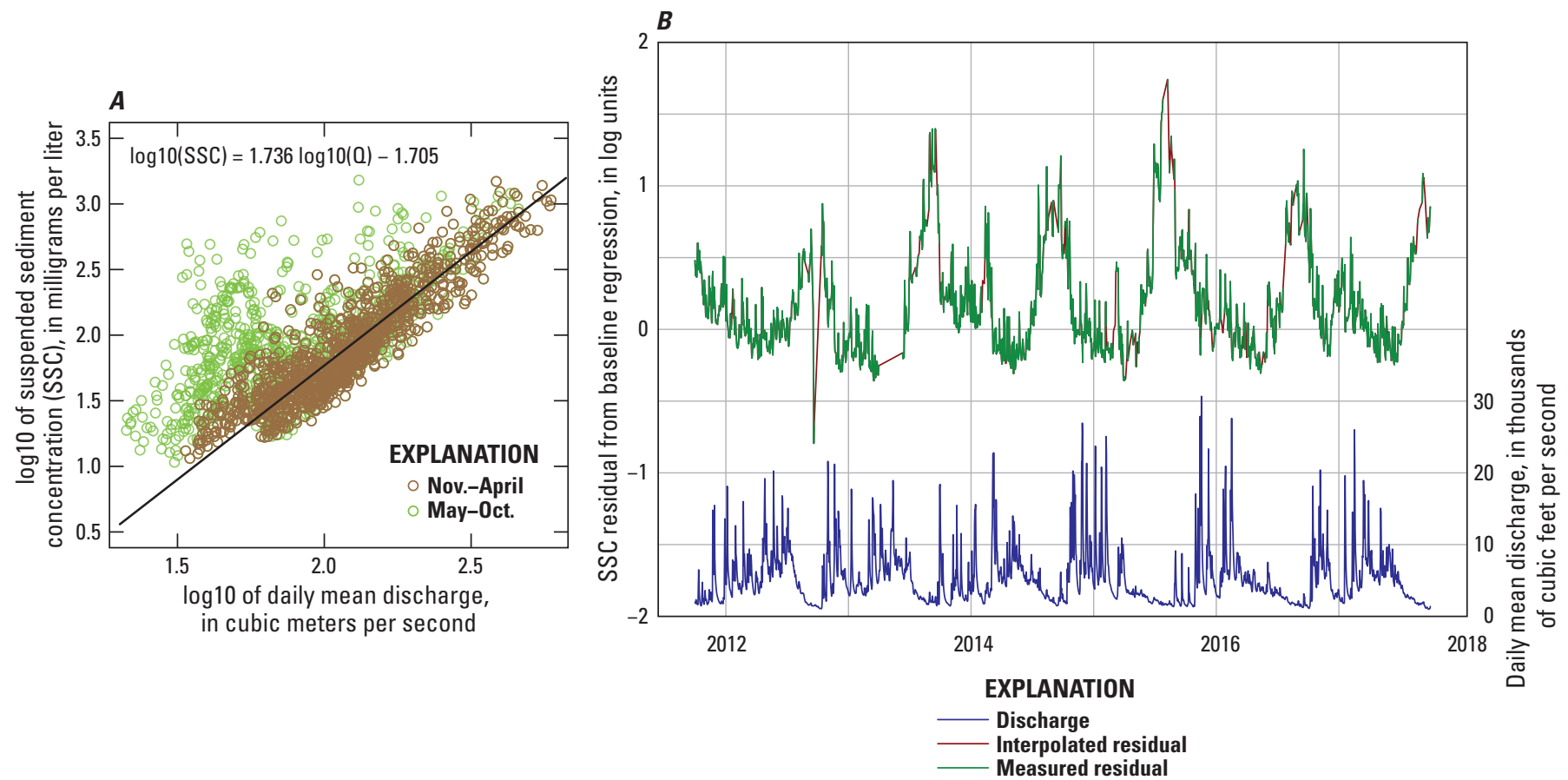

Figure 17. Example of gap-filling used to form complete daily records of suspended-sediment concentrations (SSC) and suspendedsediment loads (SSL) at glacially influenced sites, using data from Nooksack River at Ferndale, Washington (U.S. Geological Survey streamgage 12213100). (A) Regression between daily mean discharge and daily mean suspended-sediment concentration for days in November-April, when the relation between discharge and SSC was relatively well-defined. Daily mean SSC was calculated using relations between turbidity and SSC for days with complete turbidity records. (B) Residual, in log units, of daily mean SSC relative to regression shown in $A$, plotted over time.

\section{Sediment Load for the Nooksack Basin}

Sediment loads at Ferndale provide an estimate of the total sediment load exiting the Nooksack basin. Over the period of record from WY 2012 to 2017, annual SSLs at Ferndale ranged from 0.71 to 1.17 million tons and averaged 0.9 million tons (fig. 18, table 9). This is equivalent to an average suspended-sediment yield of 1,150 tons per square mile per year $\left(\left[\mathrm{ton} / \mathrm{mi}^{2}\right] / \mathrm{yr}\right)$. The SSL was made up of 53 percent silt and clay $(<0.063 \mathrm{~mm})$ and 47 percent sand. Bedload to total load ratios for the two available bedload measurements, both made at around $15,650 \mathrm{ft}^{3} / \mathrm{s}$, were 6.3 and 7.8 percent; bedload was composed of about 55 percent sand and 45 percent gravel (table 10). Assuming the bedload to total load ratio and grain size distribution of those two bedload measurements are representative of the entire period of record, the annual average sediment load from WY 2012 to 2017 would be 0.97 million tons, composed of 49 percent silt and clay, 48 percent sand (carried primarily in suspension), and 3 percent gravel (table 11). The majority of that load is carried during high flows in the autumn and winter months (fig. 18); the upper 10th quantile of flows was generally responsible for greater than 75 percent of the total SSL (fig. 19).

\section{Sub-Basin Suspended-Sediment Loads}

Most of the suspended sediment discharged by the Nooksack River to Bellingham Bay is balanced by inputs from the upper reaches of the three major forks (fig. 20). In WY 2016, the sole year with a complete record for all five sites, the combined fine sediment inputs from the $307 \mathrm{mi}^{2}$ of gaged area in the South, Middle, and upper North Fork basins represented about 83 percent of the SSL at Ferndale, while the remaining $479 \mathrm{mi}^{2}$ in the lower North Fork and mainstem basin accounted for only about 17 percent. This low value still likely over-estimates net sediment production in the true lower basin, because upland sediment from Glacier Creek, draining off Mount Baker, enters the North Fork below the streamgage site and is included in that 17 percent. Sediment yields (load divided by drainage area) in the North, Middle, and South Forks were an order of magnitude higher than those estimated in the two lower sub-basins (fig. 12; table 9). 


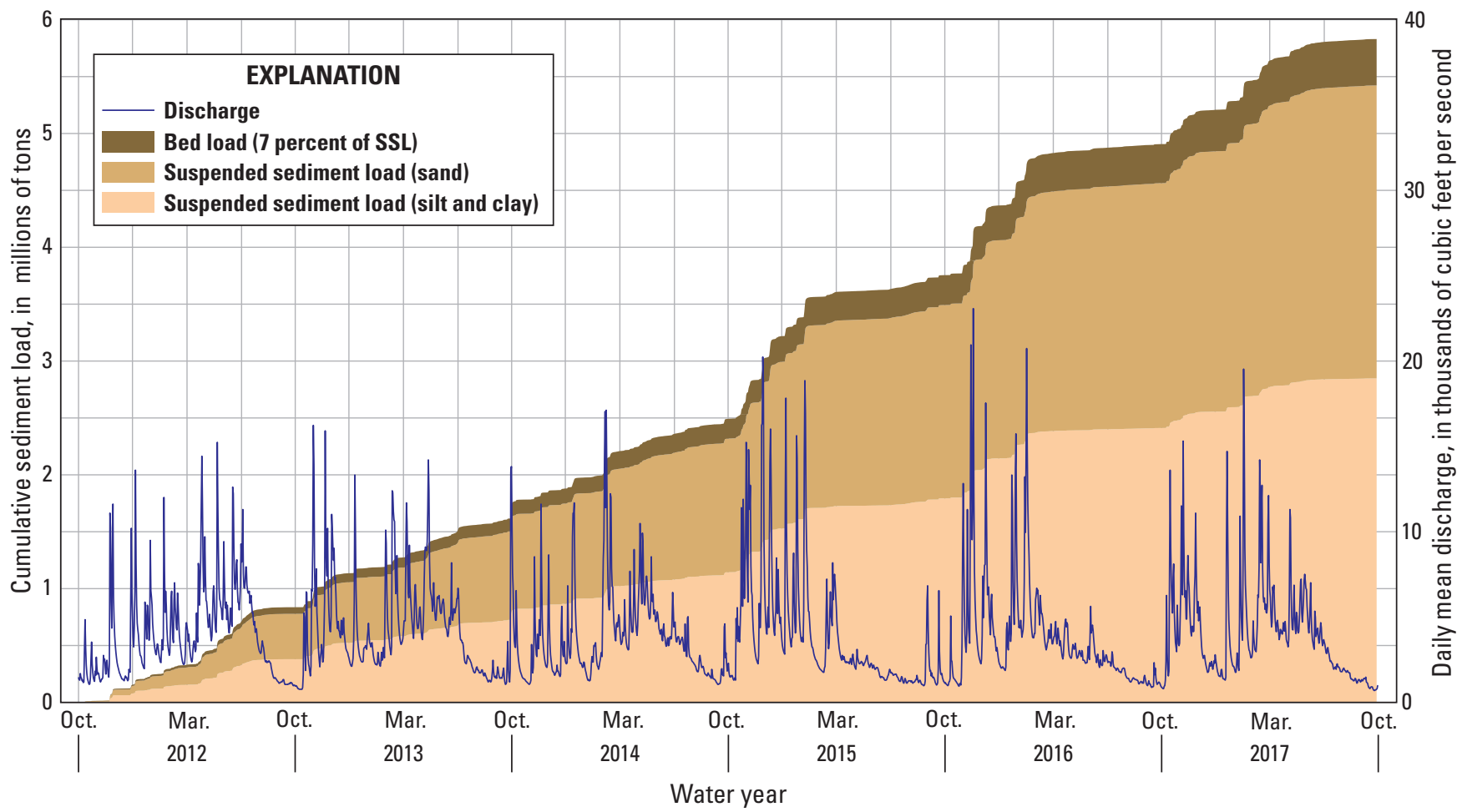

Figure 18. Cumulative sediment loads at Nooksack River at Ferndale, Washington (U.S. Geological Survey streamgage 12213100), October 1, 2011, to September 30, 2017. Suspended-sediment load was partitioned into sand and silt/clay fractions based on independent regressions between total suspended-sediment concentration and turbidity and fine $(<0.063$ millimeter) suspended-sediment concentration and turbidity. Bedload was estimated as a constant fraction of the suspended-sediment load, based on several concurrent measurements of bedload and suspended load.

Table 9. Annual suspended-sediment loads at streamgages, Nooksack River basin, northwestern Washington, 2006-15.

[Abbreviations: NC, North Cedarville; SF, South Fork; MF, Middle Fork; (ton/mi²)/yr, ton per square mile per year; -, no data]

\begin{tabular}{|c|c|c|c|c|c|c|c|c|}
\hline \multirow[b]{2}{*}{$\begin{array}{l}\text { Water } \\
\text { year }\end{array}$} & \multicolumn{5}{|c|}{$\begin{array}{l}\text { Monitored suspended sediment load } \\
\text { (tons) }\end{array}$} & \multicolumn{3}{|c|}{$\begin{array}{l}\text { Mass-balance estimated sediment contribution } \\
\text { (tons) }\end{array}$} \\
\hline & $\begin{array}{l}\text { Upper North } \\
\text { Fork }\end{array}$ & $\begin{array}{l}\text { Middle } \\
\text { Fork }\end{array}$ & $\begin{array}{l}\text { South } \\
\text { Fork }\end{array}$ & $\begin{array}{c}\text { North } \\
\text { Cedarville }\end{array}$ & Ferndale & $\begin{array}{l}\text { Lower North Fork } \\
\text { (NC - all forks) }\end{array}$ & $\begin{array}{c}\text { All North } \\
\text { Fork } \\
\text { (NC - MF - } \\
\text { SF) }\end{array}$ & $\begin{array}{c}\text { Lower basin } \\
\text { (Ferndale - } \\
\text { NC) }\end{array}$ \\
\hline 2010 & - & - & 240,000 & - & - & - & - & - \\
\hline 2011 & - & - & 240,000 & - & - & - & - & - \\
\hline 2012 & - & - & 130,000 & 730,000 & 780,000 & - & - & 50,000 \\
\hline 2013 & - & - & 110,000 & 980,000 & 830,000 & - & - & $-150,000$ \\
\hline 2014 & - & 110,000 & 120,000 & 600,000 & 710,000 & - & 370,000 & 110,000 \\
\hline 2015 & - & 230,000 & 250,000 & 990,000 & $1,170,000$ & - & 510,000 & 180,000 \\
\hline 2016 & 220,000 & 240,000 & 430,000 & $1,020,000$ & $1,070,000$ & 130,000 & 350,000 & 50,000 \\
\hline 2017 & - & 100,000 & - & - & 860,000 & - & - & - \\
\hline $\begin{array}{c}\text { 2014-16 } \\
\text { average load }\end{array}$ & $1_{260,000}$ & 190,000 & 270,000 & 870,000 & 980,000 & ${ }^{1} 150,000$ & 410,000 & 110,000 \\
\hline $\begin{array}{c}2014-16 \\
\text { average yield } \\
\left(\left[\text { ton } / \mathrm{mi}^{2}\right] / \mathrm{yr}\right)\end{array}$ & ${ }^{1} 2,480$ & 2,590 & 2,090 & 1,480 & 1,250 & 1530 & 1,060 & 560 \\
\hline
\end{tabular}

\footnotetext{
${ }^{1}$ Average loads for the upper and lower North Fork were estimated by assuming that the partitioning of the load in WY 2016 (220,000 tons, or 63 percent, from the upper and 130,000 tons from the lower) was the same for the entire period.
} 
Table 10. Summary of bedload measurements made at Nooksack River at Ferndale, Washington (U.S. Geological Survey streamgage 12213100), 2017.

[Abbreviations: BL, bed load; D50, median grain size diameter; $\mathrm{ft}^{3} / \mathrm{s}$, cubic foot per second; (lb/ft)/s, pound per foot per second; $1 \mathrm{~b} / \mathrm{s}$, pound per second; mm, millimeter; TL, total load; <, less than]

\begin{tabular}{|c|c|c|c|c|c|c|c|c|c|c|c|}
\hline \multirow{2}{*}{ Date } & \multirow{2}{*}{$\begin{array}{l}\text { Start } \\
\text { time }\end{array}$} & \multirow{2}{*}{$\begin{array}{l}\text { End } \\
\text { time }\end{array}$} & \multirow{2}{*}{$\begin{array}{c}\text { Discharge } \\
\left(\mathrm{ft}^{3} / \mathrm{s}\right)\end{array}$} & \multirow{2}{*}{$\begin{array}{l}\text { Sand fraction } \\
\text { (percent } \\
<2 \mathrm{~mm} \text { ) }\end{array}$} & \multicolumn{2}{|c|}{$\begin{array}{c}\text { D50 } \\
(\mathrm{mm})\end{array}$} & \multirow{2}{*}{$\begin{array}{l}\text { Maximum } \\
\text { size bin } \\
(\mathrm{mm})\end{array}$} & \multirow{2}{*}{$\begin{array}{c}\text { Unit bed load } \\
\text { transport rate } \\
\text { ([lb/ft]/s) }\end{array}$} & \multicolumn{2}{|c|}{$\begin{array}{c}\text { Transport rate } \\
(\mathrm{lb} / \mathrm{s})\end{array}$} & \multirow{2}{*}{$\begin{array}{l}\text { BL to } \mathrm{TI} \\
\text { ratio }\end{array}$} \\
\hline & & & & & $\begin{array}{c}\text { All } \\
\text { material }\end{array}$ & $\begin{array}{c}\text { Gravel } \\
\text { only }\end{array}$ & & & Bedload & $\begin{array}{l}\text { Suspended } \\
\text { load }\end{array}$ & \\
\hline January 19 & 1300 & 1504 & 15,650 & 61 & 1.1 & 8.8 & $16-32$ & 0.18 & 47 & 701 & 6.3 \\
\hline February 17 & 1008 & 1242 & 15,675 & 48 & 2.3 & 7.5 & $16-32$ & 0.23 & 59 & 703 & 7.8 \\
\hline
\end{tabular}

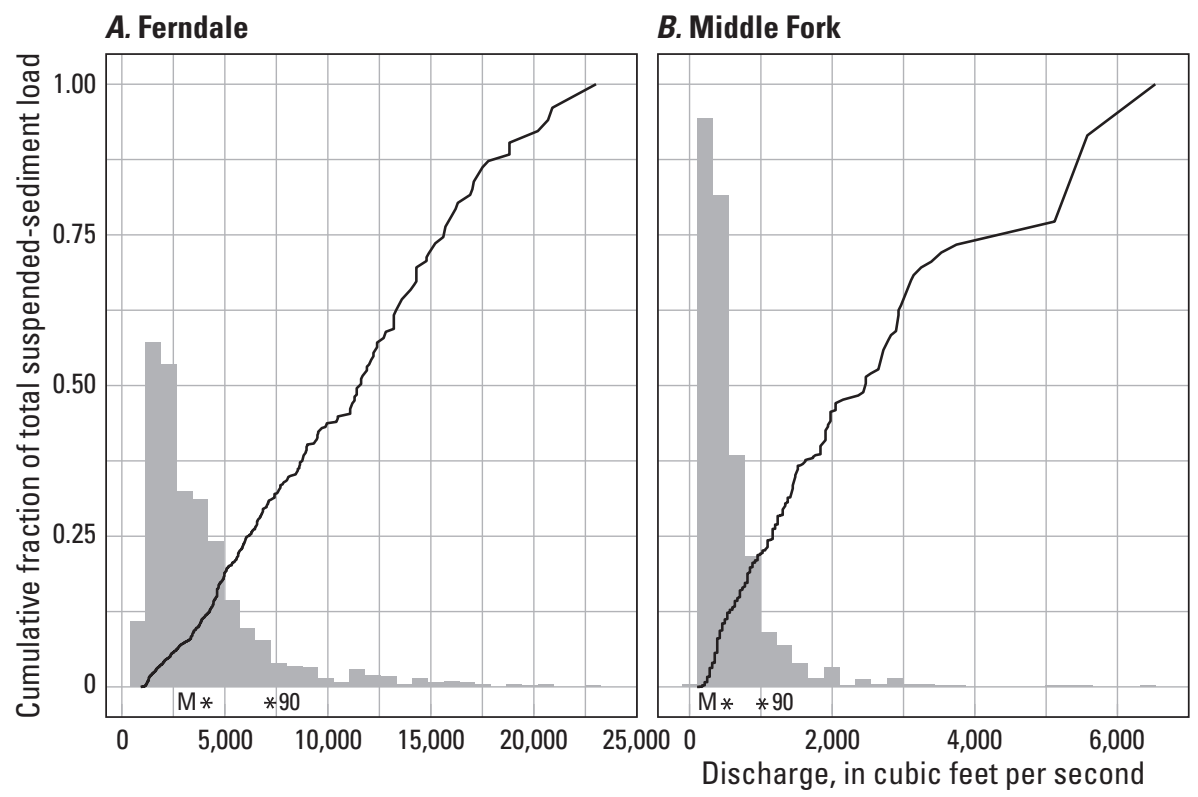

\section{South Fork}

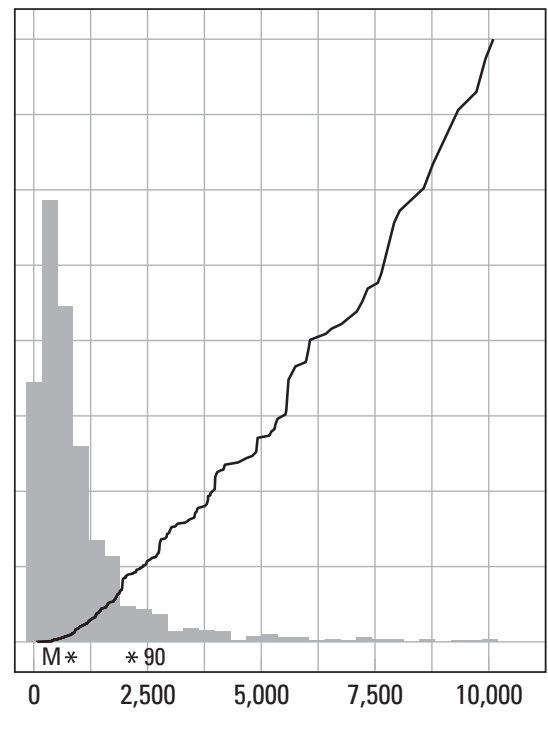

Figure 19. Cumulative fraction of suspended-sediment load as a function of daily mean discharge at $(A)$ Nooksack River at Ferndale, Washington (U.S. Geological Survey [USGS] streamgage 12213100); Nooksack River at Ferndale; $(B)$ Middle Fork Nooksack River near Deming, Washington (USGS streamgage 12208000); and (C) South Fork Nooksack River at Saxon Bridge, Washington (USGS streamgage 12210000). Grey histograms show histogram of daily mean discharge. Mean annual discharge (M) and 90th percentile daily mean discharge (90) are indicated for each gage.

Table 11. Summary of mean annual sediment load of Nooksack River at Ferndale, Washington (U.S. Geological Survey streamgage 12213100), water years 2012-17.

[Abbreviations: mm, millimeter; ton/yr, ton per year]

\begin{tabular}{lcc}
\hline \multicolumn{1}{c}{ Sediment } & $\begin{array}{c}\text { Load } \\
\text { (ton/yr) }\end{array}$ & $\begin{array}{c}\text { Percentage of } \\
\text { total load }\end{array}$ \\
\hline Mean annual total sediment load & 970,000 & 100 \\
\hline \multicolumn{2}{c}{ Partitioning by transport mode } \\
Suspended & 900,000 & 93 \\
Bedload & 70,000 & 7 \\
\hline \multicolumn{2}{c}{ Partitioning by grain size $(\mathrm{mm})$} \\
Silt and clay $(<0.063)$ & 475,000 & 49 \\
Sand, suspended $(0.063-2.0)$ & 425,000 & 44 \\
Sand, bed load $(0.063-2.0)$ & 38,000 & 4 \\
Gravel $(>2.0)$ & 32,000 & 3 \\
\hline
\end{tabular}

During WYs 2014-16, the three forks contributed roughly similar amounts of sediment to the system (averaging about 200,000-250,000 tons/yr), and each accounted for about 20-40 percent of the total load at Ferndale. The load from the upper North Fork over this period, which was not gaged in WY 2014 or 2015, was estimated by noting that in WY 2016, the needed upper North Fork supplied about 63 percent of the mass-balance estimated sediment load from the total load from North Fork. The WYs 2014 to 2016 average sediment input from the total load at North Fork was then multiplied by 0.63 to estimate the mass of sediment supplied by the upper North Fork basin. 


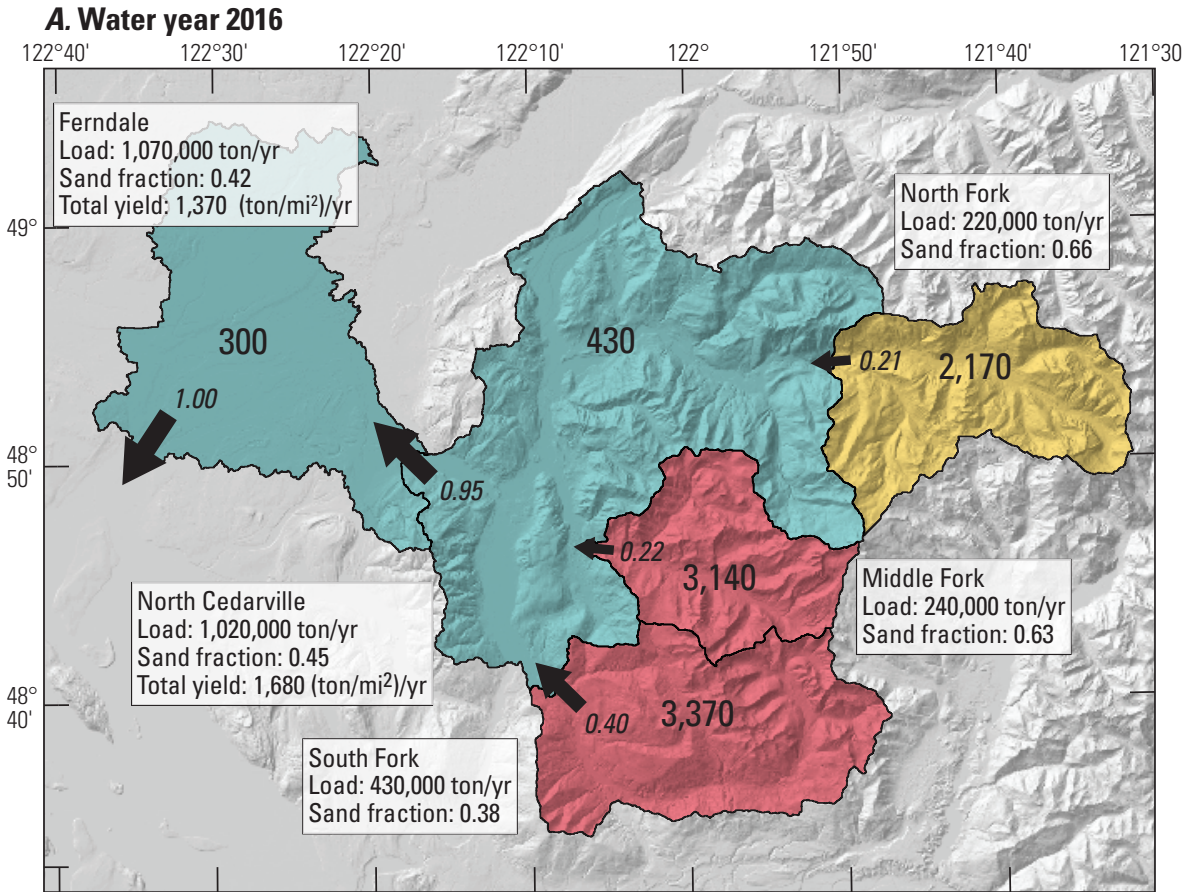

\section{B. Water years 2014-16}

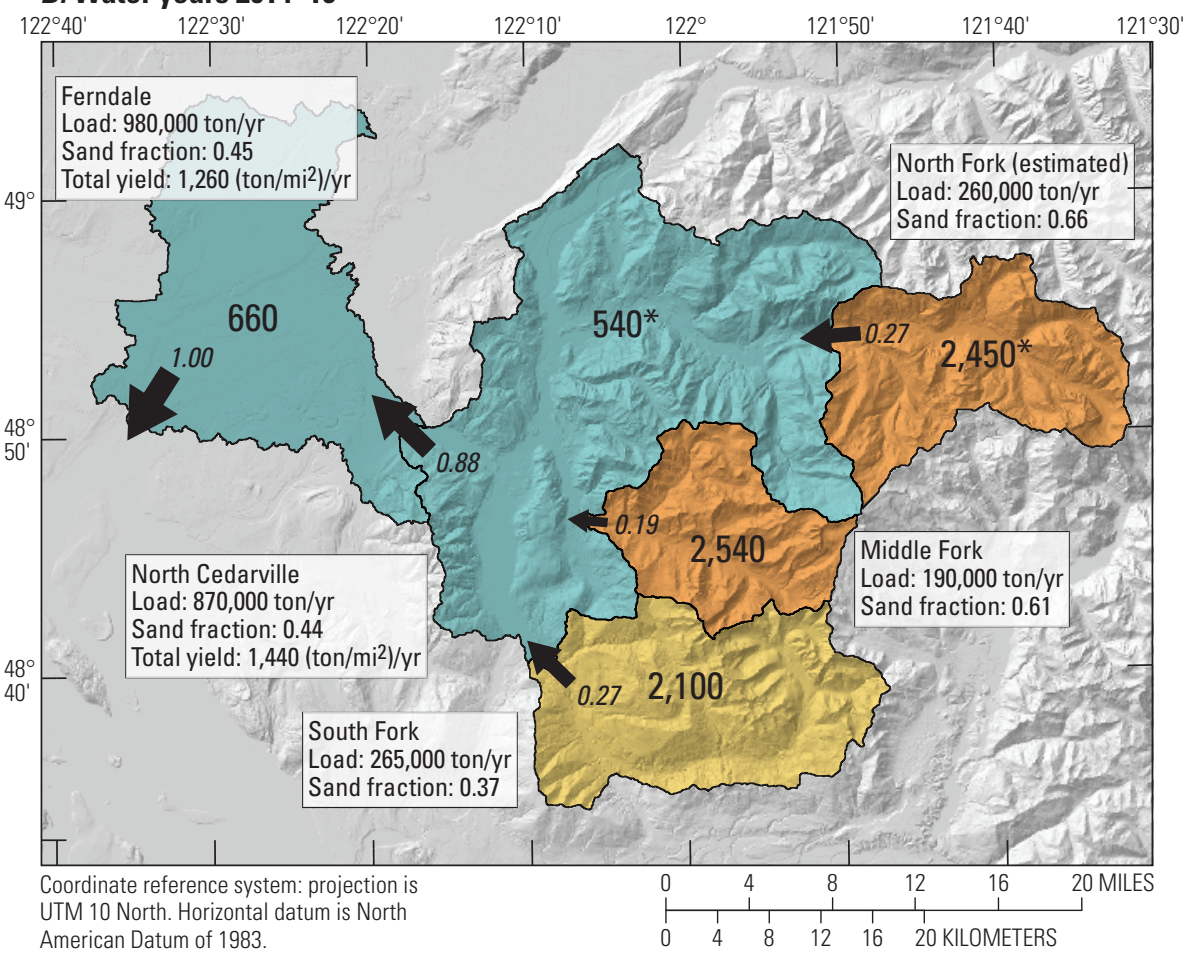

Figure 20. Suspended-sediment loads and yields in the Nooksack River by subbasin, northwestern Washington. (A) Results for water year (WY) 2016, the only year with complete records for all sites. $(B)$ Results for WYs 2014-16. Yields in the lower North Fork and lower mainstem Nooksack River were estimated through mass balance between streamgages.

\section{EXPLANATION}

2,170 Suspended sediment yield, in tons per square mile per year-Asterisk indicates 2014-16 sub-basin yields that are estimated based on the partitioning in 2016

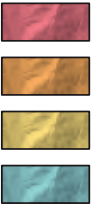

Greater than 3,000

2,000 to 3,000

1,000 to 2,000

Less than 1,000

0.22 Fraction of load at Ferndale -Arrow size is proportional to value 
The South Fork Nooksack, despite the absence of active glaciation, exported suspended sediment at rates similar to the Middle and North Fork over the study period. However, there were systematic differences between the basins in terms of the composition of that suspended sediment; in the glaciated North and Middle Fork, the suspended load was predominately (60-65 percent) sand, while the suspended load in the South Fork was only 37 percent sand. Combined with the difference in planform character (active braided or anabranching in the North and Middle Fork, suggesting high volumes of bedload transport versus more single-threaded in the lower South Fork, suggesting relatively lower bedload transport), it is likely that the North and Middle Fork supply a relatively larger fraction of the coarse sand and gravel in the lower river than would be indicated by their fractional contribution to the suspended load.

\section{Suspended-Sediment Balance in the Mainstem Nooksack}

Over the shared period of record from WYs 2012 to 2016, the SSL passing Ferndale was about 5 percent higher than the suspended-sediment load at North Cedarville, and the two loads are indistinguishable within uncertainty (fig. 21). Both were composed of about 45 percent sand and 55 percent silt and clay. Because the loads at Ferndale also incorporate an unknown amount of sediment input from almost $200 \mathrm{mi}^{2}$ of low-land tributaries that enter downstream of the North Cedarville site, the similarity in loads does not necessarily imply that no accumulation has occurred; sediment lost to deposition may be offset by continued delivery downstream. However, given that the contributing area in question is almost entirely within the low-gradient Puget Lowlands, that sediment input is likely small. These results then do largely preclude the possibility that large volumes of fine sediment passing North Cedarville are being consistently deposited and stored before reaching Ferndale. These results do not imply anything about balances or sediment accumulations of coarser sediment moving as bedload.

Although the absolute imbalance between SSLs was small, there were systematic variations in that imbalance over daily, seasonal, and inter-annual timescales. The lower river-sediment balance was quantified by subtracting the North Cedarville SSL from the Ferndale SSL; positive values indicate more sediment was exiting near Ferndale than entering at North Cedarville, while negative values indicate more was entering upstream than exiting downstream. Since lower-basin tributary inputs are not known, positive values do not necessarily indicate net mobilization of fine sediment from the bed. However, periods with negative balance do indicate that fine-sediment storage is increasing and provide a minimum estimate of the change.

Negative spikes associated with individual flood events are a result of the approximately 6-hour transit time between the two sites. Seasonally, the balance was typically neutral or negative from late spring through early autumn and positive from late autumn through the following spring. This indicates a seasonal in-filling of fine sediment in the river below North Cedarville during the snow and glacial melt period and subsequent clearing of that sediment during the autumn and winter flood season. However, impacts on bed elevation are unlikely to be large; given seasonal imbalances on the order of 100,000 tons, changes in channel-bed elevation would on the order of $0.1 \mathrm{ft}$, assuming sediment was spread out evenly across the wetted channel bed. 

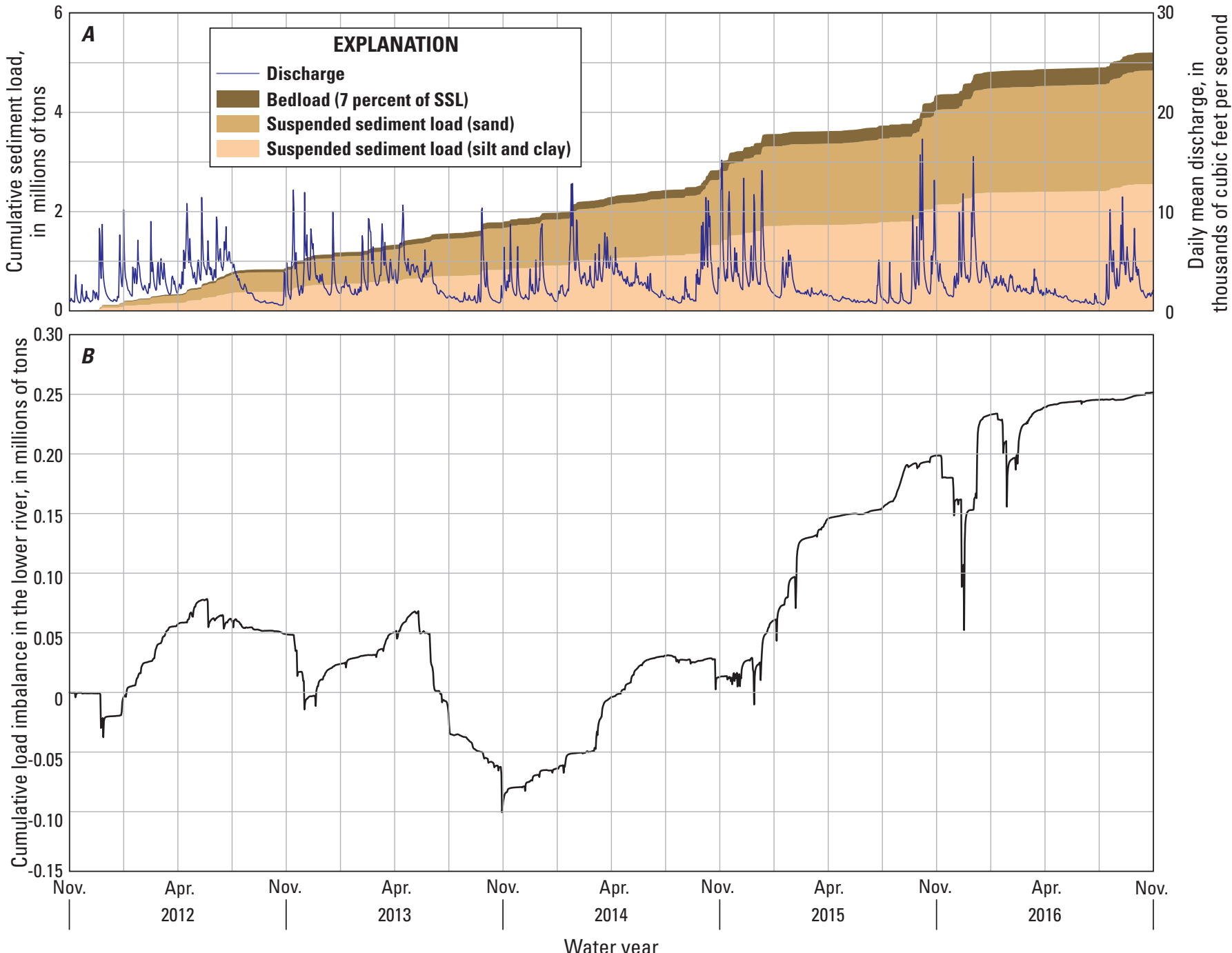

Figure 21. Discharge and cumulative suspended-sediment load at Nooksack River at Ferndale, Washington (U.S. Geological Survey [USGS] streamgage 12213100), 2012-16 (A), and cumulative load imbalance in the lower river, defined as the difference between the load at Nooksack River at Ferndale, Washington, and the load at Nooksack River at North Cedarville, Washington (U.S. Geological Survey streamgage USGS 12210700), (B) northwestern Washington. Increasing values indicate more sediment exiting the reach than entering, whereas decreasing values indicate more sediment entering than exiting. 


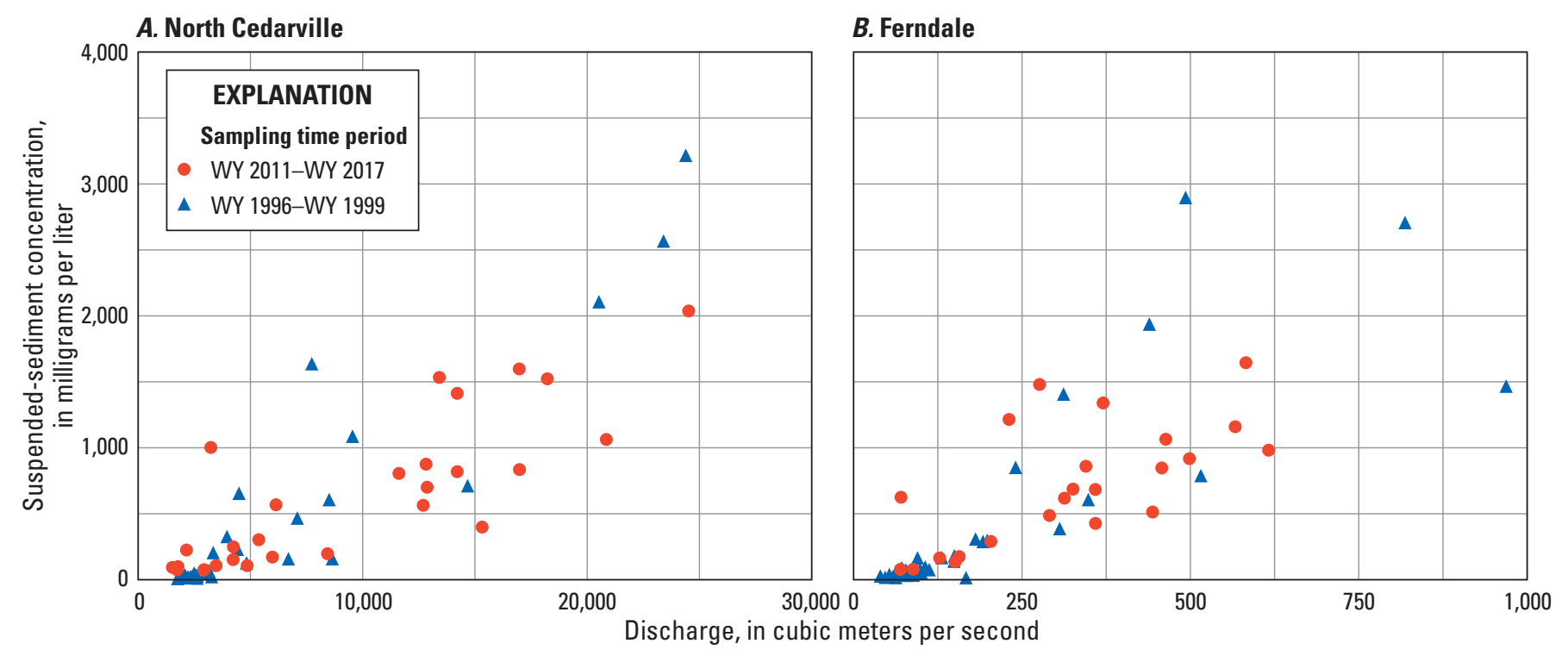

Figure 22. Comparison of suspended-sediment-discharge $(A)$ at Nooksack River at North Cedarville, Washington (U.S. Geological Survey streamgage 12210700) and $(B)$ at Nooksack River at Ferndale, Washington (U.S. Geological Survey streamgage 12213100).

\section{Consistency of Suspended-Sediment-Content- Discharge Relations over Time}

From 1996 to 1999, numerous SSC measurements were made near the Ferndale and North Cedarville gages. At both sites, the relation between SSC and discharge for those older measurements is indistinguishable from that relation for measurements made since 2011 (fig. 22). Although the relation between discharge and SSC may vary substantially over the short term (for example, fig. 17), the consistency of the SSCdischarge relation for these two time periods indicates that fine sediment availability from 2011-16 was not systematically different from conditions in the late 1990s. Relations between SSC and discharge are similar between the two sites, and all measurements in both time periods and at both sites could reasonably be combined into a single lower-river dischargeSSC rating curve as an approximate estimate of long-term suspended-sediment transport.

\section{Floodplain Drainage and Recent Trends in Precipitation, Streamflow, and Stage}

Trends in monthly precipitation, discharge, and stage data from selected locations in the Nooksack River basin were compared to identify potential factors influencing poor drainage along the Nooksack River. Locations were selected to represent each of the forks and the mainstem of the Nooksack River.
Estimates of daily precipitation for 1981-2013 were obtained from Livneh and others (2015) at four locations in the Nooksack River basin representing points in the South Fork (N48.65625/W121.968765); Middle Fork (N48.78125/ W121.96875), North Fork (N48.90625/W121.90625), and main valley around Lynden (N48.90625/W122.53125). Total precipitation depth and number of days when precipitation was greater than $0.1 \mathrm{in} /$ day were calculated for each month. Trends in the annual values of each statistic were assessed for each month using linear regression of the statistic and year. Coefficients that had a probability less than 0.05 of equaling zero were considered significant. The values of the coefficients represent the mean rate of change per year of the respective parameters over the periods of analysis, but changes in precipitation, streamflow, and stage were not necessarily occurring as steady trends over time.

Daily mean streamflow for water years and stage for water years were obtained from NWIS (U.S. Geological Survey, 2018) for the North Fork (12205000), Middle Fork (12208000), South Fork (12210000), Deming (12210500), North Cedarville (12210700), and Ferndale (12213100) gages. The periods of available record varied by parameter and site. Monthly mean and maximum streamflow were calculated for available records from water years 1981-2017 for the North Fork and Ferndale gages, from 1981 to 2008 for the Deming gage, from 1993-2017 for the Middle Fork gage, and from 2009-2017 for the South Fork gage. Monthly median and 90th percentile of daily stage values were calculated starting in 1992 at Ferndale, 1995 at the North Fork, 1996 at the Middle Fork, 2003 at North Cedarville, and 2009 at the South Fork. 
Table 12. Trends indicated by Pearson product-moment correlation coefficients for annual values of precipitation, streamflow, and stage statistics with year, Nooksack River basin, northwestern Washington, 1981-2013.

[Column headings show abbreviated U.S. Geological Survey streamgage names and numbers. Values indicate trend rate for a given metric per year. Abbreviations: in., inch; $\mathrm{ft}$, foot; $\mathrm{ft}^{3} / \mathrm{s}$, cubic foot per second; $\mathrm{p}>0.05$, greater than 0.05 ; -, no significant trend; >, greater than;]

\begin{tabular}{|c|c|c|c|c|c|c|c|c|c|c|}
\hline \multirow[b]{2}{*}{ Months } & \multicolumn{5}{|c|}{ Trend in monthly precipitation (in.) } & \multicolumn{5}{|c|}{ Trend in number of days with precipitation >0.1 in. (days/yr) } \\
\hline & $\begin{array}{l}\text { North Fork } \\
1981-2013\end{array}$ & $\begin{array}{l}\text { Middle Fork } \\
\text { 1981-2013 }\end{array}$ & $\begin{array}{l}\text { South Fork } \\
1981-2013\end{array}$ & $\begin{array}{l}\text { Lynden } \\
\text { 1981-2013 }\end{array}$ & & $\begin{array}{l}\text { North Fork } \\
1981-2013\end{array}$ & $\begin{array}{c}\text { Middle Fork } \\
\text { 1981-2013 }\end{array}$ & $\begin{array}{l}\text { South Fork } \\
\text { 1981-2013 }\end{array}$ & $\begin{array}{l}\text { Lynden } \\
\text { 1981-2013 }\end{array}$ & \\
\hline January & - & - & - & - & & - & - & - & - & \\
\hline February & -0.13 & -0.17 & -0.21 & -0.06 & & - & - & - & - & \\
\hline March & 0.16 & 0.16 & 0.20 & - & & 0.23 & 0.22 & 0.23 & 0.12 & \\
\hline April & - & - & - & - & & - & - & - & - & \\
\hline May & - & 0.91 & - & - & & - & - & - & - & \\
\hline June & - & - & - & - & & - & - & - & - & \\
\hline July & -0.08 & -0.10 & -0.10 & -0.03 & & -0.19 & -0.18 & - & - & \\
\hline August & - & - & - & - & & - & - & - & - & \\
\hline September & - & - & - & - & & - & - & - & - & \\
\hline October & - & - & - & - & & - & - & - & - & \\
\hline November & - & - & - & - & & - & - & - & - & \\
\hline \multirow[t]{2}{*}{ December } & - & - & - & - & & - & - & - & - & \\
\hline & \multicolumn{5}{|c|}{ Trend in monthly mean streamflow $\left(\mathrm{ft}^{3} / \mathrm{s}\right)$} & \multicolumn{5}{|c|}{ Trend in maximum daily streamflow $\left(\mathrm{ft}^{3} / \mathrm{s}\right)$} \\
\hline Months & $\begin{array}{c}\text { North Fork } \\
12205000 \\
1981-2017\end{array}$ & $\begin{array}{c}\text { Middle Fork } \\
12208000 \\
\text { 1993-2017 }\end{array}$ & $\begin{array}{c}\text { South Fork } \\
12210000 \\
2009-17\end{array}$ & $\begin{array}{c}\text { Deming } \\
12210500 \\
1981-2005\end{array}$ & $\begin{array}{c}\text { Ferndale } \\
12213100 \\
1981-2017\end{array}$ & $\begin{array}{c}\text { North Fork } \\
12205000 \\
1981-2017\end{array}$ & $\begin{array}{c}\text { Middle Fork } \\
12208000 \\
1993-2017\end{array}$ & $\begin{array}{c}\text { South Fork } \\
12210000 \\
2009-2017\end{array}$ & $\begin{array}{c}\text { Deming } \\
12210500 \\
1981-2005\end{array}$ & $\begin{array}{c}\text { Ferndale } \\
12213100 \\
1981-2017\end{array}$ \\
\hline January & - & - & - & - & - & - & 2.57 & - & - & - \\
\hline February & - & 0.29 & 4.49 & - & - & - & 2.25 & 22.81 & - & - \\
\hline March & - & 0.37 & 3.92 & - & 1.32 & - & - & - & - & - \\
\hline April & - & - & - & - & - & - & - & - & - & - \\
\hline May & - & 0.33 & - & - & - & - & - & - & - & - \\
\hline June & - & - & - & - & - & - & - & - & - & - \\
\hline July & - & - & - & - & - & - & - & - & - & - \\
\hline August & - & - & - & - & - & - & - & - & - & - \\
\hline September & - & - & - & - & - & 0.80 & - & - & - & - \\
\hline October & - & - & - & - & - & - & - & - & - & - \\
\hline November & - & 0.50 & - & - & - & - & - & - & - & - \\
\hline \multirow[t]{2}{*}{ December } & - & - & - & 2.01 & - & - & - & - & - & - \\
\hline & \multicolumn{5}{|c|}{ Trend in median daily stage (ft) } & \multicolumn{5}{|c|}{ Trend in 90th percentile of daily stage } \\
\hline Months & $\begin{array}{c}\text { North Fork } \\
12205000 \\
1995-2017\end{array}$ & $\begin{array}{c}\text { Middle Fork } \\
\text { 12208000 } \\
\text { 1996-2017 }\end{array}$ & $\begin{array}{c}\text { South Fork } \\
12210000 \\
2009-17\end{array}$ & $\begin{array}{c}\text { Cedarville } \\
12210700 \\
2003-17\end{array}$ & $\begin{array}{c}\text { Ferndale } \\
12213100 \\
1992-2017\end{array}$ & $\begin{array}{c}\text { North Fork } \\
12205000 \\
1995-2017\end{array}$ & $\begin{array}{c}\text { Middle Fork } \\
12208000 \\
1996-2017\end{array}$ & $\begin{array}{c}\text { South Fork } \\
12210000 \\
2009-17\end{array}$ & $\begin{array}{c}\text { Cedarville } \\
12210700 \\
2003-17\end{array}$ & $\begin{array}{c}\text { Ferndale } \\
12213100 \\
1992-2017\end{array}$ \\
\hline January & 0.02 & - & - & - & - & 0.03 & - & - & - & - \\
\hline February & 0.02 & - & 0.02 & 0.02 & 0.01 & 0.03 & - & 0.07 & 0.04 & - \\
\hline March & 0.03 & 0.01 & 0.04 & 0.02 & 0.03 & 0.03 & 0.01 & 0.06 & - & 0.04 \\
\hline April & 0.03 & 0.01 & - & - & 0.02 & 0.03 & - & - & - & 0.02 \\
\hline May & 0.03 & 0.01 & - & - & 0.02 & 0.03 & - & - & - & 0.02 \\
\hline June & 0.03 & - & - & - & 0.02 & 0.03 & - & -0.04 & - & - \\
\hline July & 0.03 & - & - & - & 0.02 & 0.03 & - & - & - & - \\
\hline August & 0.03 & - & -0.02 & - & 0.02 & 0.03 & - & -0.02 & - & - \\
\hline September & 0.03 & - & - & - & 0.02 & 0.03 & - & - & - & - \\
\hline October & 0.03 & - & - & - & 0.02 & 0.04 & - & - & - & - \\
\hline November & 0.03 & - & - & 0.02 & 0.03 & 0.03 & - & - & 0.03 & 0.05 \\
\hline December & 0.02 & - & - & - & - & 0.02 & - & - & - & - \\
\hline
\end{tabular}




\section{Trends in Monthly Precipitation, Streamflow and Stage}

Monthly precipitation from 1981 to 2013 decreased at all four locations in February and July and increased in the North Fork, Middle Fork, and South Fork basins in March (table 12). The increase represents a trend of about 2 inches per decade. The number of days with $>0.1 \mathrm{in} / \mathrm{d}(2.5 \mathrm{~mm})$ of precipitation increased from 1981 to 2013 at all four locations in March, representing a trend of an additional 1-2 days in each month per decade when precipitation $>0.1 \mathrm{in} / \mathrm{d}$.

Monthly mean streamflow increased from 1981 to 2017 at the Middle Fork, South Fork, and Ferndale streamgages in March (table 12). Trends in mean streamflow were not significant for any other month at the North Fork or Ferndale gage. The Middle and South Fork streamgages had increasing trends in February and March (both streamgages), and May and November (Middle Fork) during recent years. Maximum daily streamflow had few significant trends in any month at any of the gages and none at Ferndale. The largest trend was an increase in February in the South Fork.

Median daily stage increased in every month at the North Fork streamgage from 1995 to 2017 and every month except December and January at Ferndale gage from 1992-2017 (table 12). Given the lack of corresponding trends in mean monthly streamflow, these trends in stage are attributed primarily to the increase in bed elevation over this same period (fig. 10). The 90th percentile of daily stage, representing the highest stage exceeded on 3 days each month, also increased in every month at the North Fork gage but only for March, April, May, October, and November at Ferndale. The highest rates of increase at Ferndale were in March ( 0.03 foot per decade [ft/decade] for median daily stage and 0.4 feet per decade for the 90th percentile of daily stage) and November $(0.3 \mathrm{ft} /$ decade for median daily stage and $0.5 \mathrm{ft} / \mathrm{decade}$ for the 90th percentile of daily stage).

\section{Areas Susceptible to Drainage Issues With Increased Stage}

Increased stage in the Nooksack River could aggravate poor drainage in low-lying areas that rely on gravity drainage systems or where the groundwater table is shallow. Areas susceptible to drainage impacts due to increased stage can be identified based on the elevation of the land surface relative to the local water surface elevation of the river (Konrad, 2015).

Water-surface elevations of the river from the 2013 lidar were extrapolated across valley bottom and subtracted from the land-surface elevations to create a raster of the height of the land surface above a nominal low-water surface (HAWS). The spatial extrapolation was performed using inverse-distance weighting (power $=1$, search radius of $3,000 \mathrm{ft}$, minimum of 100 points) on points spaced every $100 \mathrm{ft}$ along the river using ArcTools (ESRI, 2016). Values in the HAWS raster close to 0 indicate low-lying areas where the land surface elevation is close to the local water surface elevation of the river. These areas are likely to have drainage issues more frequently than adjacent areas with higher values. The HAWS raster does not account for surface connections to the river, so it includes areas where local precipitation or groundwater in addition to high streamflow may contribute to poor drainage.

The Nooksack River valley is characterized as a "glacial" type by Collins and Montgomery (2011) where post-glacial alluvial deposition along the river has not filled in the uniformly across the valley floor. As a result, there are expansive low-lying areas where flooding and drainage are frequent issues. Although local hydraulic analysis is required for precise estimation of the frequency and extent of flooding, the HAWS grid indicates the spatial extent of low-lying areas and their potential expansion if river stage increases in the future (fig. 23). Currently, the largest extent of low-lying areas ( $<2 \mathrm{ft}$ above the water surface of the river) is south of Brennan/Slater Road. These areas generally are separated from the river by low $(2-5 \mathrm{ft})$ natural levees formed from overbank deposition of sediment in addition to engineered levees. In addition, substantial areas between Everson and Lynden are within a range ( $2-5 \mathrm{ft})$ that is comparable to observed variation in bed elevation from specific-gage analysis. These areas could be subject to increased flooding and drainage issues in response to channel aggradation. 


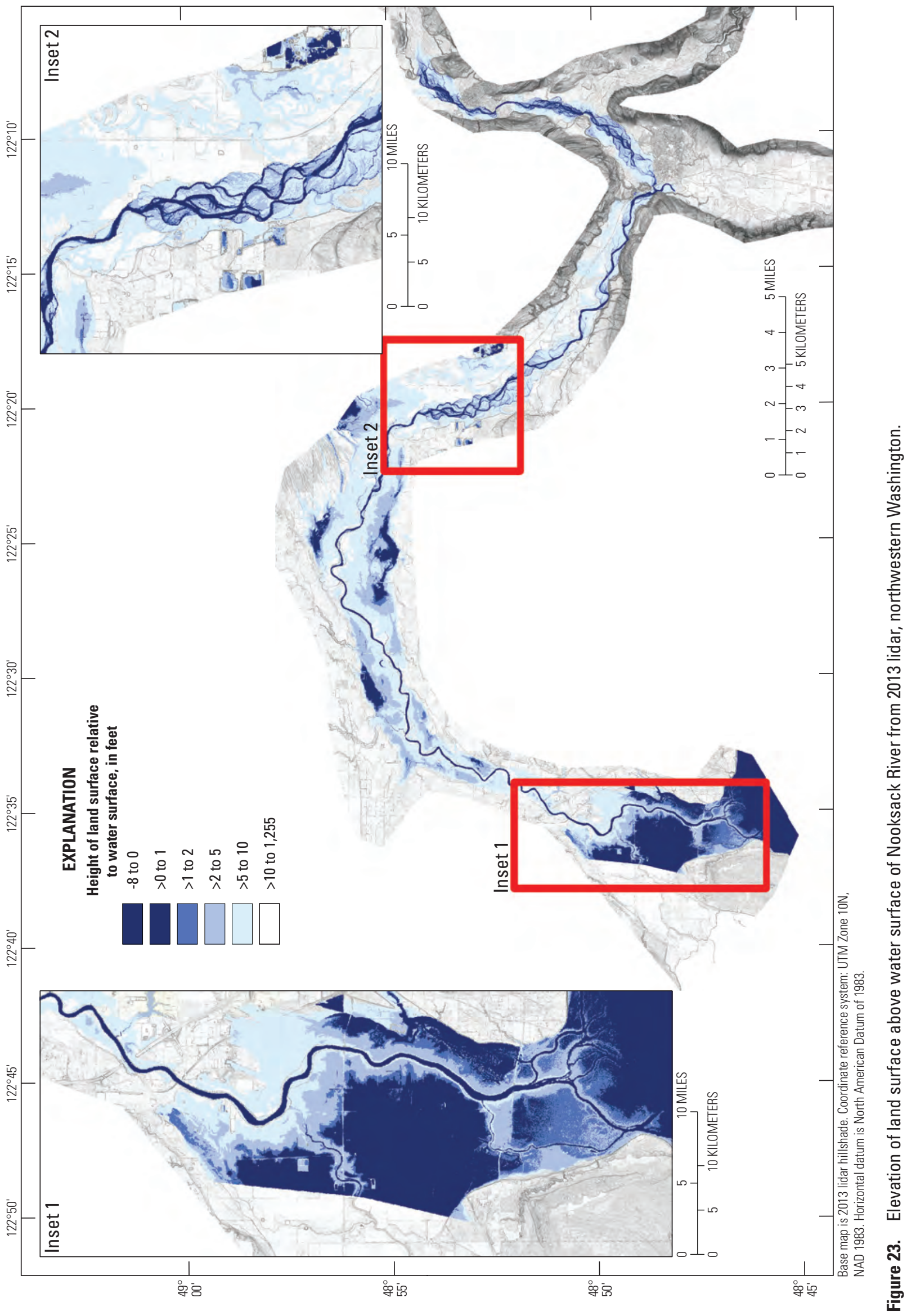




\section{Dynamics of Water-Surface Elevations, River Bed Elevations, and Suspended- Sediment Transport in the Lower Mainstem Nooksack River}

Continuous stage (WYs 2006-17), river-bed elevations (2006 and 2015), and continuous (WYs 2016-17) turbidity records collected downstream of Ferndale were examined to assess longitudinal variation in channel conveyance with respect to streamflow and its potential influence on sediment storage. The stage of the river was monitored continuously at 15-minute intervals at Nooksack River at Ferndale, Washington (USGS 12213100) during WYs 2016 and 2017, at Nooksack River at Brennan, Washington (USGS 12213140) from October 30, 2015, to October 27, 2017, and at Nooksack River at Marine Drive Bridge near Bellingham, Washington (USGS 12213145) from October 7, 2015, to October 13, 2017 (U.S. Geological Survey, 2018) and converted into watersurface elevations (WSE) above North American Vertical Datum of 1988. Presuming uniform streamflow in the lower river, shifting relations in instantaneous WSE measurements among the gages indicate the variable influences of streamflow, tides, and, potentially, transient (storm- to seasonal-scale) in-channel sediment storage.

Turbidity was monitored continuously at Ferndale during WYs 2012-17. Turbidity was well correlated with SSC (Curran and others, 2018). Shifting relations between streamflow and turbidity at Nooksack River at Ferndale, Washington (USGS 12213100) indicate transient changes in storage of fine sediment in the mainstem river channel upstream of Ferndale.

\section{Relations Between Water-Surface Elevations at Ferndale, Brennan, and Marine Drive}

Water-surface elevations at Brennan (Slater Road) and Marine Drive was well correlated with WSE at Ferndale, with approximately equal magnitude of variation over the range of streamflow observed in WYs 2016-17 (fig. 24). Ferndale is above significant tidal influence of Bellingham Bay, while the Brennan and Marine Drive sites are both tidally influenced. As a result, the relation between WSE at Ferndale and WSE at the two tidal sites showed increasing variability at lower streamflows. Variable backwater conditions at Brennan were apparent at flows less than approximately $2,600 \mathrm{ft}^{3} / \mathrm{s}$, and resulted in a $+/-0.5 \mathrm{ft}$ variability in WSE at Brennan for a given WSE at Ferndale. Variable backwater condition at Marine Drive due to tides are more common, occurring when streamflow less than $6,000 \mathrm{ft}^{3} / \mathrm{s}$ (about $8.9 \mathrm{ft}$ WSE) at Ferndale and produce a range in WSE approximately $4 \mathrm{ft}$ at Marine Drive for a given WSE at Ferndale. During low tides, represented by the lowest values of WSE at Marine Drive for a given value of WSE at Ferndale in figure 24, the variation in WSE at Marine Drive about equal to the variation at Ferndale for lower to moderate streamflow. At higher flows $(>16 \mathrm{ft}$ WSE at Ferndale), the WSE at Marine Drive varies much less than the WSE at Ferndale, indicating a smaller increase in WSE at Marine Drive compared to Ferndale during high flows. As a result, the water surface gradient of the river remained relatively constant between Ferndale and Brennan over the range of observed streamflow for WYs 2015-17, but it increased from Brennan to Marine Drive during high flows.

\section{Longitudinal Profile of the Lower Nooksack River}

The Nooksack River downstream of Ferndale has a water surface slope that varies with streamflow and tides, which can affect sediment transport. From Ferndale to Brennan/Slater Road, the slope is generally about 0.0003 (as seen in the 2013 lidar) but approaches 0.0005 during either low or high flow conditions. The slope decreases downstream of Brennan/ Slater Road to Marine Drive to around 0.0002 for a range of moderate flows. During floods, the slope from Ferndale down to Marine drive becomes relatively uniform at around 0.0005 . At low flows, water surface slopes below Brennan/Slater road may also vary from 0.00004 to -0.00004 depending on tidal conditions.

The longitudinal profile of the river bed downstream of Ferndale during late summer 2015 had a median absolute deviation of $0.002(0.73 \mathrm{ft} / 330 \mathrm{ft})$, which is greater than the mean slope of the reach. When mean cross-sectional elevations are averaged over a 3,000 ft moving window (fig. 25), a mound of sediment centered around RM 2 and extending a mile upstream and downstream is evident. It is uncertain whether this mound is a transient feature that will travel downstream, a seasonal feature formed in response to low sediment transport capacity during late summer, or a persistent channel form. Comparison of 2006 cross sections to the 2015 bathymetry indicates recent aggradation in this vicinity (fig. 5), suggesting it may be more persistent than a seasonal (low-flow) accumulation. Downstream movement or upstream expansion cannot be resolved by comparing 2015 bathymetric to the 2006 cross-sections due to the wide spacing of the 2006 cross-sections in these lower reaches. 

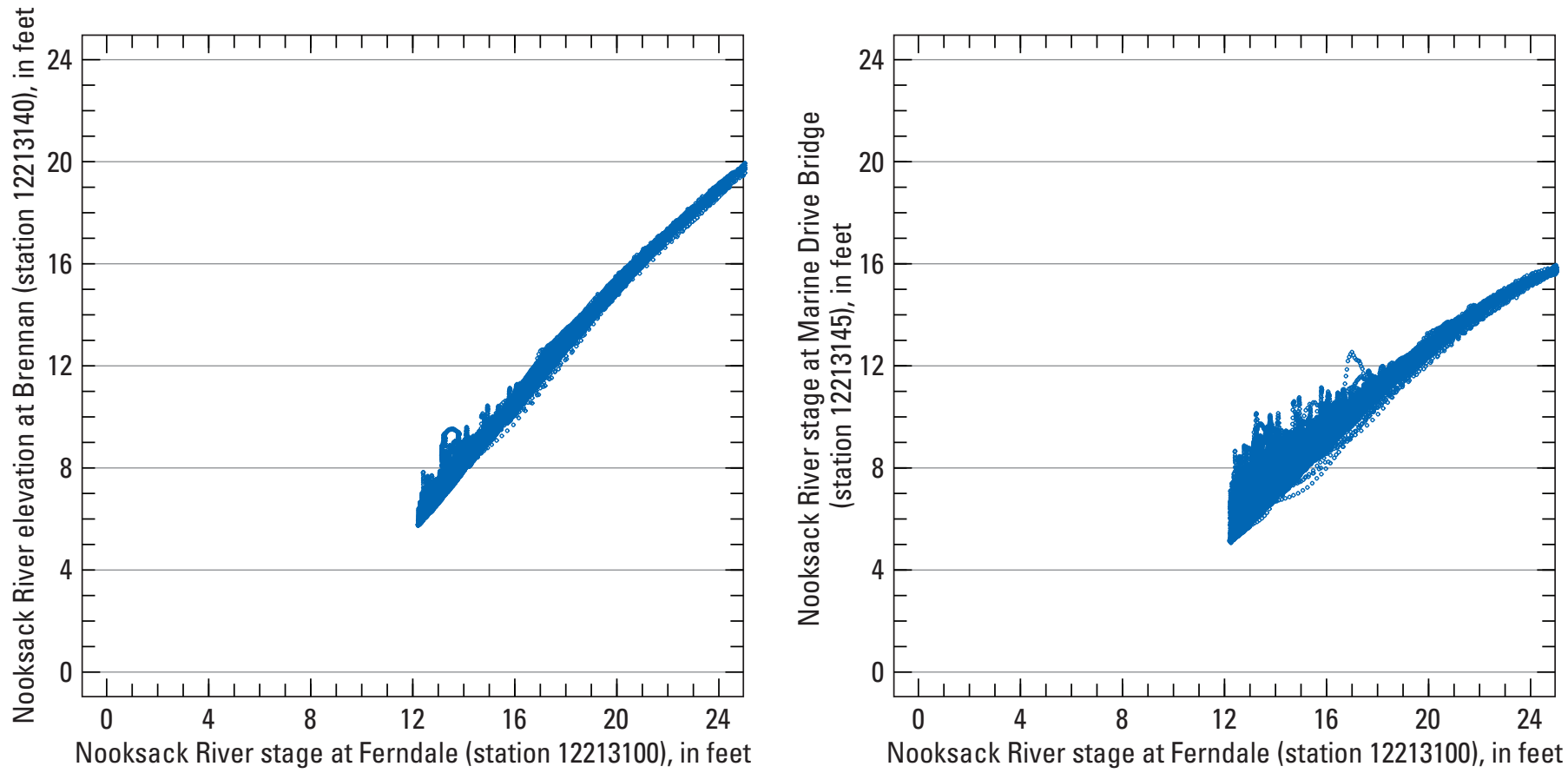

Figure 24. Relations between water-surface elevations at $(A)$ Nooksack River at Ferndale, Washington (U.S. Geological Survey [USGS] streamgage 12213100) and Nooksack River at Brennan, Washington (USGS streamgage 12213140), and (B) Nooksack River at Marine Drive Bridge near Bellingham, Washington (USGS streamgage 12213145).

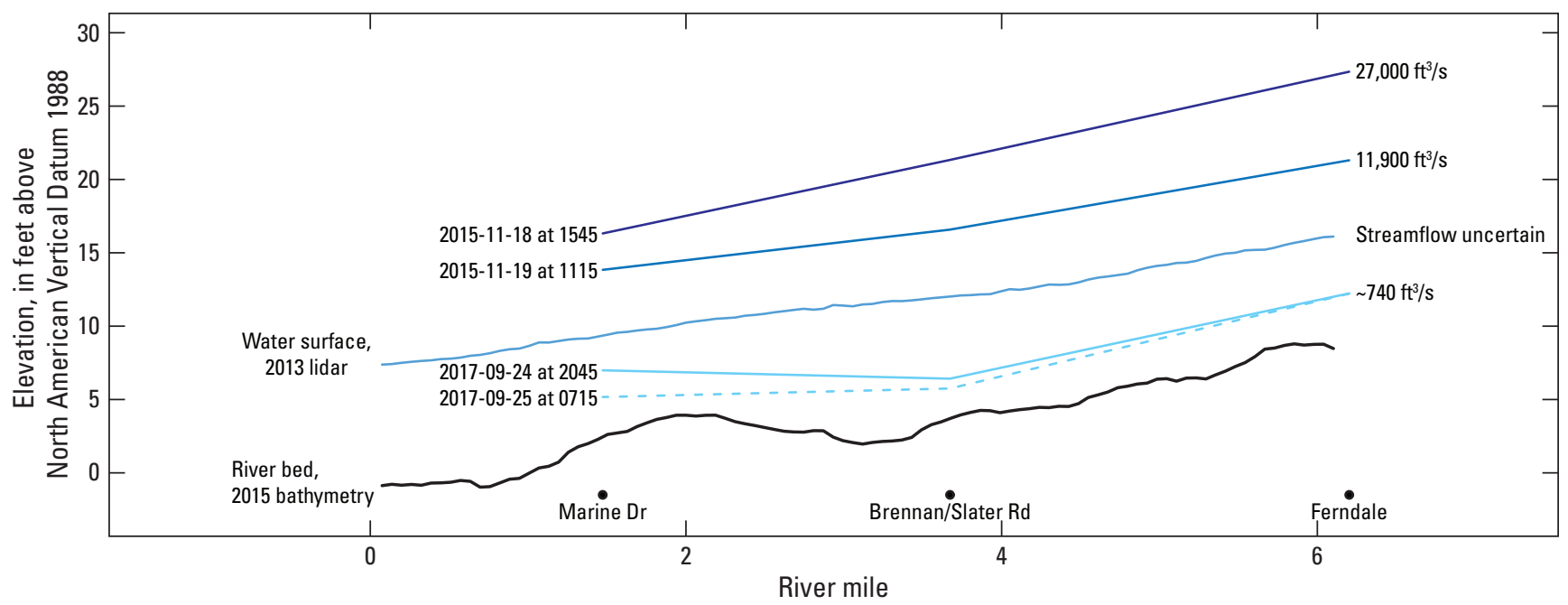

Figure 25. Longitudinal profile of the Nooksack River over a range of streamflow values, northwestern Washington. Bathymetry for 2015 is 3,000 -foot moving average. 
Collins and Sheikh (2004) estimated that the Nooksack River delta prograded into Bellingham Bay about $1.3 \mathrm{mi}$ from 1887 to 1998 ( $0.11 \mathrm{mi}$ per decade) as the river deposited sediment at its mouth. Generally, the longitudinal extension of the river delta reduces the water surface gradient of the lower river, leading to increased sediment deposition until the river bed has aggraded enough to transport the sediment load delivered from upstream. This process can be viewed as a rising profile at a location or a downstream shift of any given elevation along the profile. An upper limit on channel aggradation can be estimated from the river bed profile assuming the shape of the profile is maintained but the entire profile shifts downstream at the rate of delta pro-gradation. Given slopes of $0.0002,0.0002$, and 0.00063 , respectively, for the Nooksack River bed above Ferndale, Brennan, and Marine Drive, aggradation expected due solely to delta progradation is

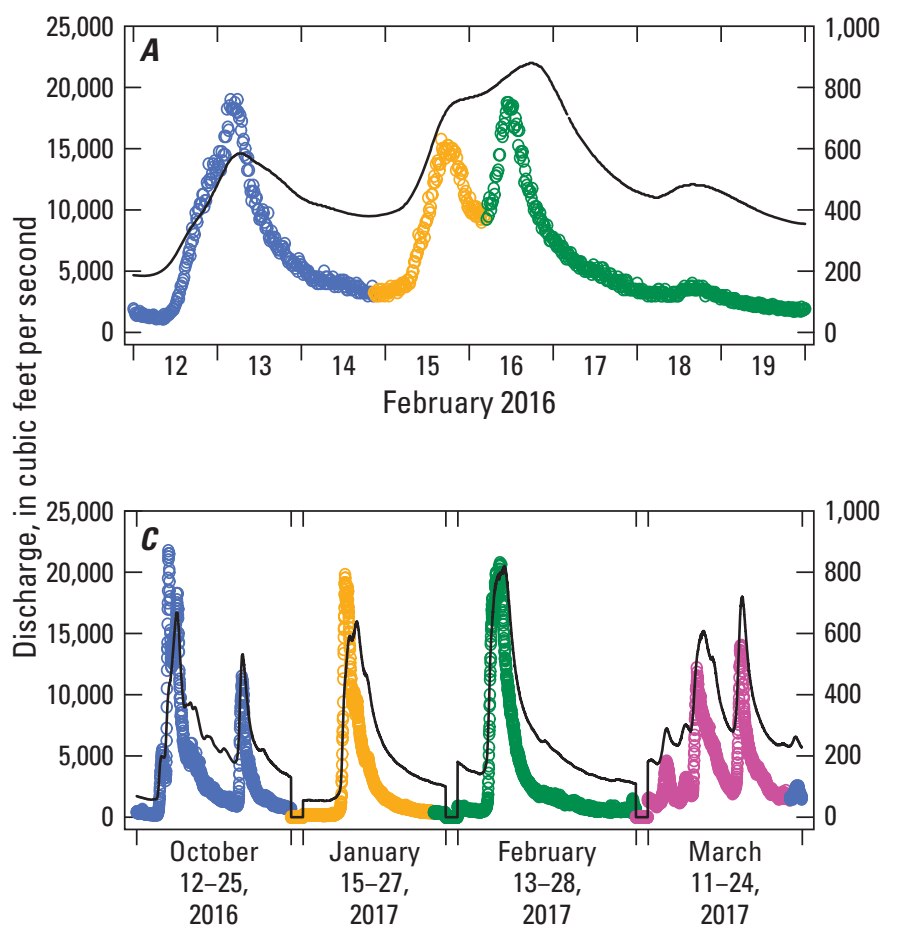

about 0.11 feet per decade (ft/decade), $0.13 \mathrm{ft} / \mathrm{decade}$, and 0.37 $\mathrm{ft} /$ decade, respectively. This does not account for hydraulic changes during floods or any changes in the shape of the river bed profile.

\section{Seasonal- and Storm-Scale Patterns in Turbidity at Ferndale}

Temporal patterns in relations between streamflow and turbidity at Ferndale indicate seasonal and storm-scale variation in the transport and in-channel storage of fine sediment (fig. 26). Turbidity generally varied with streamflow but demonstrates more than two orders of magnitude variation at lower flows $\left(<10,000 \mathrm{ft}^{3} / \mathrm{s}\right)$, typically due to the dischargeindependent delivery of fine sediment from glaciers during the summer.

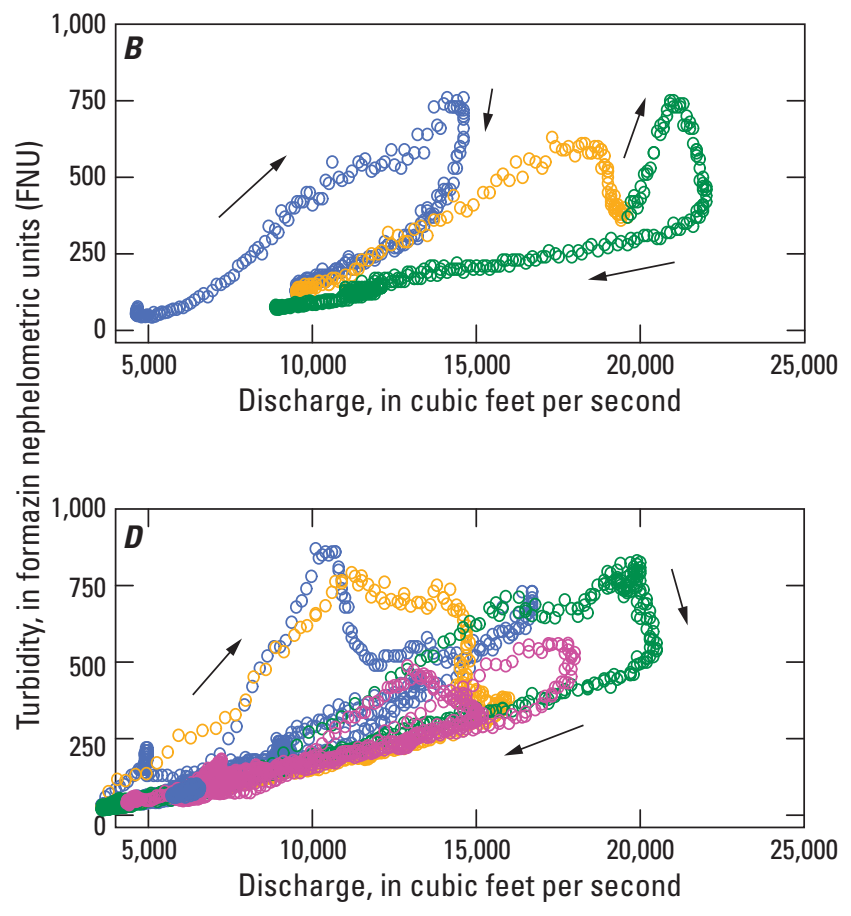

Figure 26. Turbidity and discharge at Nooksack River at Ferndale, Washington (U.S. Geological Survey streamgage 12213100) for selected storms. (A) Turbidity and discharge over time for sequence of high flows in early 2016. (B) Turbidity compared with discharge for data shown in $A$, demonstrating clock-wise hysteresis over individual floods and over sequence of floods. $(C)$ Turbidity and discharge for individual floods during water year 2017; different floods separated by various amounts of time are visually plotted in sequence. (D) Turbidity compared with discharge for period shown in $C$, demonstrating longer-term clock-wise hysteresis over seasonal time-scales. 
Turbidity at Ferndale has consistent storm- and seasonalscale patterns (fig. 26). During individual storms, turbidity for a given discharge was usually higher on the rising limb than on the falling limb. At the beginning of a storm, streamflow entrains more fine sediment from the river bed than it deposits, so turbidity is relatively high. Over the course of a storm, there is less fine sediment readily available to entrain from the river bed to balance the sediment that settles out of the water column. This pattern produced "clockwise" hystersis in plots of turbidity versus streamflow for individual storms, and similar patterns of decreasing turbidity as a function of streamflow for a series of storms and for the wet season from late autumn to spring. During periods of lower streamflow, fine sediment accumulates in the channel, thus re-setting the relation between turbidity and streamflow. The seasonal pattern of higher fine sediment availability on the bed during summer and flushing during winter upstream of Ferndale observed in the turbidity relations is not apparent in either specific-gage analysis at Ferndale or the WSE-WSE relations for the lower river stations, indicating that fine sediment accumulations are not having significant impacts on water surface elevations.

\section{Future Monitoring}

The results of this study suggest several avenues for continued monitoring of channel change in the Nooksack River. Most broadly, results presented here highlight that changes in water-surface elevation, holding discharge constant, generally scale with mean bed elevation change. This is most evidently true in confined reaches, where the wetted channel covers a large fraction of the active channel, but changes in water surface elevation from 2006-13 appear to have also reasonably approximated both the direction and magnitude of mean changes in valley storage in broad, unconfined reaches as well.

The simplest application of this observation is to continue to monitor changes in stage-discharge relations at streamgages at Ferndale, Everson, North Cedarville, and the upper North Fork. Current USGS policy is to upload new streamflow measurements into the National Water Information System (https://waterdata.usgs.gov/nwis/measurements), so ongoing changes in stage-discharge relations change can be tracked.

The monitoring of stage-discharge relations at gages can be extended to any nearby location, where discharge is close to the discharge at a gage, by making regular measurements of water-surface elevation at those sites. For long-term analysis, measurements should be converted to an elevation relative to a known datum (for example, North American Vertical Datum of 1988), using RTK-GPS or a survey tied to a benchmark. Once several measurements over modest range of discharges have been made to define the "baseline" stage-discharge relation, future measurements can be used to assess changes in stage-discharge relation relative to that baseline. These measurements of stage would ideally coincide with streamflow measurements at the proximate gage, since that is the only time that discharge is actually measured and not simply estimated based on stage at the gage site.

Over larger spatial-scales, boat-based longitudinal water-surface elevation surveys, collected using survey-grade RTK-GPS and targeted towards a narrow range of discharges, may provide a reasonable alternative to more time-intensive bathymetry surveys as a means of regularly monitoring vertical channel change. Such surveys could reasonably be accomplished over much of the lower river on an annual or semi-annual basis, and could inform where more information or attention was needed.

As the cost of aerial lidar decreases and the quality improves, the practical utility of repeat aerial lidar surveys continues to increase. Aerial lidar surveys acquired at 5-7year intervals would provide complete view of both vertical and horizontal channel change, excluding the submerged portion of the channel. Such surveys would be most useful over the reaches upstream of Lynden, where most of the active channel is emergent at low flows. Photogrammetric surveys, such as acquired in 2015, are substantially cheaper and faster to process than aerial lidar but are limited by the inability to penetrate vegetation. Photogrammetric surveys may then be an efficient tool for regularly monitoring short project reaches or as a rapid-response tool, but are unlikely to provide an efficient replacement for aerial lidar. 


\section{Conclusions}

\section{Changes in Channel Storage from 2005/06 to 2013/15}

Comparisons of various topography and bathymetric data in the lower Nooksack River indicate that the channel around Ferndale and Everson have both experienced significant local aggradation from 2005/06 to 2013/15, with mean bed elevations increasing by about $1-2$ feet. The reach between Everson and Ferndale appears to have been largely stable; this matches qualitative assessments of the repeat cross-sections and field inspections, though quantitative interpretation is limited by the quality of the 2015 bathymetry over that intervening reach. In contrast, the majority of the North Fork and mainstem Nooksack, upstream of Everson and below the Glacier Creek confluence, was net incisional from 2005/062013. Finer-scale longitudinal patterns of channel change indicate that there were approximately six distinct reaches, spanning about 2-10 miles, over which mean net changes were relatively consistent. Transitions between these reaches were associated with distinct valley constrictions. Relating these observations to modeled reach-scale hydraulics and the specific history of floods that occurred during and prior to the survey interval would likely provide insight into shortterm controls on sediment accumulation and storage over reach-scales.

\section{Magnitude of Net Channel Change Relative to Sediment Transport Rates}

Rates of suspended-sediment transport provide context for the magnitude of net channel change from 2006 to 2013. From WY 2010 to 2016, annual suspended-sediment transport at North Cedarville averaged 850,000 (ton/yr). In comparison, annual average net erosion upstream of North Cedarville from 2006 to 2013 was estimated to be between 156,000 and 720,000 tons per year (ton/yr). Using the low end of the uncertainty range for both the total eroded mass and the fraction of bed material contained in that mass, the estimated delivery of bed material of about 60,000 ton/yr would imply a minimum bedload to total load ratio of 7 percent at the North Cedarville site. Over the full range of plausible rates of net erosion and bed material fraction, the estimated bedload to total load ratio ranged from about $10-40$ percent. All these values only account for bed material supplied through net erosion of bed in the upper mainstem and lower North Fork; true bedload transport rates are undoubtedly higher due to throughput bedload and inputs from the Middle and South Fork. These results broadly indicate that bedload was likely a substantial fraction of the total load at North Cedarville, and almost certainly larger than the 7 percent estimated at Ferndale. If bedload may have plausibly made up 10 to 50 percent of the annual load at North Cedarville over this time period, average annual bedload transport at North Cedarville from 2006 to 2013 would range from about 100,000 to 800,000 ton/yr.

\section{Long-Term Bed-Elevation Trends}

\section{Changes in stage-discharge relations at USGS} streamgages in the Nooksack basin indicate the presence of a broad, 2-3-foot-high bed wave, sourced from the upper North Fork Nooksack. That wave has been translating downstream at a slope-dependent rate of about $0.5-2.5$ miles per year. The overall shape of the wave is well-correlated with regional climate variability, with a 20 -year lag between the initial climate signal and subsequent channel response in the upper North Fork. Given the 45-year lag between bed change in the upper North Fork and bed change at Ferndale, the lag between initial climate forcing and subsequent bed response at Ferndale is about 65 years.

These results would indicate that climate-driven variations in the rate of sediment delivery from the upper North Fork Nooksack have been a dominant control on long-term bedelevation trends at all the downstream streamgage sites. At the long-term gages in the North Fork, near Deming, and at Ferndale, the climate index developed here can explain about 60-70 percent of the variance over their respective periods of record. The ability to explain the majority of the historic bed-elevation change as a function of historic climate without invoking the history of upstream land-use, channel modifications or gravel extraction, implies those latter processes may have secondary or more localized influences on bed-elevation trends. This corroborates the results of Kerr Wood Leidal (2008), who noted that changes in bed elevation at the Ferndale and Deming gages were not clearly related to concurrent hydrology or gravel extraction, and instead suggested the possibility of a wave moving down the North Fork.

The interpretation presented here indicates that bedelevation changes at the upper North Fork gage should be repeated at downstream streamgages with known lag times. This provides a strong test on this interpretation; if, over the next 5-8 years, changes at the downstream streamgages continue to follow predicted trends, confidence that this interpretation is correct should increase. If borne out, these results would then imply that long-term bed elevation trends at downstream streamgage sites would be predictable, providing a forecast of expected bed elevation trends over the coming decades. Predictions based on the upper North Fork records would currently forecast that the bed near Ferndale should re-incise and enter a several-decades long period of incision; however, incision in the lower river may be limited by armoring and base-level controls from Bellingham Bay. The bed near Everson would be forecast to continue to aggrade at a relatively consistent rate of about 1 foot per decade for at least the next two decades, based on observed change in the North Fork, and potentially for the next 3-4 decades if the relation between climate and subsequent channel change remains consistent. 
In addition to the long-term trends observed at all gages, shorter-term periods of fill and scour were apparent in the upper North Fork and, to a lesser degree, near Deming. These shorter-wavelength features were not apparent at any of the gages below RM 28, consistent with the expectation that the bed response to individual or punctuated sediment pulses tends to disperse moving downstream. These results suggest that any individual landslide or debris flow in the upper basin is unlikely to have a notable impact on channel bed elevations in the lower river outside of exceptionally large events.

\section{Sediment Transport and Sources}

Sediment monitoring at five locations in the Nooksack Basin indicate that the fine-sediment load exiting the basin is predominately sourced from steeper headwater basins in each of the three forks. The lower-elevation sub-basins continue to be a net source of fine sediment, but with per-area yields an order of magnitude lower than in the upper basins. The average yield for the entire Nooksack ( 1,150 tons per square mile per year $\left[\right.$ ton $\left./ \mathrm{mi}^{2}\right] / \mathrm{yr}$ ) was lower, but of the same magnitude, as yields estimated in the nearby Sauk River $\left(1,450 \mathrm{tons} / \mathrm{mi}^{2} / \mathrm{yr}\right.$; Jaeger and others, 2017) and Stillaguamish River (2,200 tons $/ \mathrm{mi}^{2} / \mathrm{yr}$ including input from the March 2014 Oso landslide, 1,740 tons $/ \mathrm{mi}^{2} / \mathrm{yr}$ excluding landslide input; Anderson and others, 2017) over similar time periods. Yields in the upper three forks of the Nooksack were all on the order of 2,000-2,500 tons $/ \mathrm{mi}^{2} / \mathrm{yr}$, similar to sediment yields in the upper Nisqually draining Mount Rainier (3,100 tons $/ \mathrm{mi}^{2} /$ year; Czuba and others, 2012). The Nooksack then appears to produce fine sediment at a rate comparable to, or slightly lower than, similar basins in the region. In contrast to findings from Alder Lake, which indicated yields from the glaciated terrain on Mount Rainier was an order of magnitude higher than yields from the forested terrain draining the Little Nisqually River, fine sediment yields in the unglaciated South Fork Nooksack were very similar to yields from the glaciated North and Middle Forks. The divergent results may be a function of the extent of continental glaciation and the presence of extensive glacial till and glacio-lacustrine sediment, which is pervasive in the South Fork Nooksack and Stillaguamish basins but largely absent from lowlands near Mount Rainier. Despite similarities in yields, glaciated and unglaciated basins showed distinct grain size distributions. Fine sediment from the glaciated forks were composed of about 60-70 percent sand, while the South Fork was only about 30-40 percent sand. This is similar to results from the Sauk and Stillaguamish rivers, where loads from the glaciated Sauk River were 60-70 percent sand, while the unglaciated Stillaguamish was 30-40 percent sand (Anderson and others, 2017; Jaeger and others, 2017).

\section{Precipitation and Stage Trends}

Spring precipitation across the basin likely has increased since 1981 in terms of monthly totals (about 2 inches per decade) and number of days with more than 0.1 in/day ( $\sim 2$ days per decade). It is not known whether the magnitudes of these trends are sufficient to contribute to drainage issues. River stage increased recently (1992-2017) at the North Fork (both median and 90th percentiles of daily mean stage in all months) and Ferndale (median stage in February through November and 90th percentile of stage in March through May). The magnitude of change may have been sufficient to increase the duration and extent of drainage issues in lowlying areas where drainage depends on either low river stage or the elevation of the groundwater table relative to the land surface.

\section{Storm- and Seasonal-Scale Patterns of Sediment Transport}

Relations between fine sediment transport and discharge at Ferndale demonstrates storm- and seasonal-scale hysteresis, indicating progressive exhaustion of fine-sediment storage in the channel over individual or sequenced flood events, as well as a progressive decrease in storage over the autumn and winter flood season. Fine sediment storage is restored over the spring and summer. However, there are no corresponding seasonal trends in stage-discharge relations at Ferndale or in stage-stage relations between the lower stations, indicating that these variations in fine-sediment storage are not having an appreciable influence on the bed elevation or water surface elevations at either low or high discharge.

\section{Acknowledgments}

Paula Harris and John Thompson, with the Whatcom County Department of Public Works provided oversight and guidance throughout the project. Jezra Beaulieu and Oliver Grah, with the Nooksack Indian Tribe, generously supplied sediment and turbidity data for the North Cedarville, South Fork, and North Fork Nooksack River streamgaging sites. We thank Western Washington University students Nathan vanArendonk and Amelia Deuelle for assistance with sampling bedload. 


\section{References Cited}

Anderson, S.W., and Grossman, E.E., 2017, Topographic and bathymetric elevation data for the Nooksack River, Fall 2015: U.S. Geological Survey data release, https://doi. org/10.5066/F72B8W7M.

Anderson, S.W., Keith, M.K., Magirl, C.S., Wallick, J.R., Mastin, M.C., and Foreman, J.R., 2017, Geomorphic response of the North Fork Stillaguamish River to the State Route 530 landslide near Oso, Washington: U.S. Geological Survey Scientific Investigations Report 2017-5055, 85 p., https://doi.org/10.3133/sir20175055.

Anderson, S.W., and Pitlick, J., 2014. Using repeat lidar to estimate sediment transport in a steep stream: Journal of Geophysical Research-Earth Surface, v. 119, no. 3, p. 621-643.

Bunte, Kristin, and Abt, S.R., 2001, Sampling surface and subsurface particle-size distributions in wadable graveland cobble-bed streams for analyses in sediment transport, hydraulics, and streambed monitoring: U.S. Department of Agriculture, General Technical Report RMRS-GTR-744, 28 p.

Collins, B.D., and Montgomery, D.R., 2011, The legacy of Pleistoncene glaciation and the organization of lowland alluvial process domains in the Puget Sound region: Geomorphology, v. 126, p. 174-185, http://dx.doi. org/10.1016/j.geomorph.2010.11.002.

Collins, B.D., and Sheikh, A.J., 2004, Historic channel locations of the Nooksack River: University of Washington, Report to Whatcom County, Washington.

Curran, C.A., Anderson, S.W., Foreman, J.R., and Beaulieu, J., 2018, Suspended sediment concentration and loads in the Nooksack River Basin, northwest Washington: U.S. Geological Survey data release, https://doi.org/10.5066/ F7TX3DK3.

Czuba, J.A., Magirl, C.S., Czuba, C.R., Grossman, E.E., Curran, C.A., Gendaszek, A.S., and Dinicola, R.S., 2011, Sediment load from major rivers into Puget Sound and its adjacent waters: U.S. Geological Survey Fact Sheet 2011-3083, 4 p.

Czuba, J.A., Olsen, T.D., Czuba, C.R., Magirl, C.S., and Gish, C.C., 2012, Changes in sediment volume in Alder Lake, Nisqually River Basin, Washington, 1945-2011: U.S. Geological Survey Open-File Report 2012-1068, 30 p., https://pubs.usgs.gov/of/2012/1068/.

Ebbesmeyer, C.C., and Strickland, R.M., 1995, Oyster condition and climate-Evidence from Willapa Bay: University of Washington, Washington Sea Grant Program, Publication WSG-MR 95-02, 11 p.
Embrey, S.S., and Frans, L.M., 2003, Surface-water quality of the Skokomish, Nooksack, and Green-Duwamish Rivers and Thornton Creek, Puget Sound basin, Washington, 1995 98: U.S. Geological Survey Water-Resources Investigations Report 02-4190, $192 \mathrm{p}$.

Gaeuman, D., Stewart, R.L., Schmandt, B., and Pryor, C., 2017, Geomorphic response to gravel augmentation and high-flow dam release in the Trinity River, California: Earth Surface Processes and Landforms, v. 42, p. 2523-2540.

Grams, P.E., Topping, D.J., Schmidt, J.C., Hazel, J.E., and Kaplinski, M., 2013, Linking morphodynamic response with sediment mass balance on the Colorado River in Marble Canyon-Issues of scale, geomorphic setting, and sampling design: Journal of Geophysical Research—Earth Surface, v. 118, no. 2, p. 361-381.

Jaeger, K.L., Curran, C.A., Anderson, S.W., Morris, S.T., Moran, P.W., and Reams, K.A., 2017, Suspended sediment, turbidity, and stream water temperature in the Sauk River Basin, Washington, water years 2012-16: U.S. Geological Survey Scientific Investigations Report 2017-5113, 47 p., https://doi.org/10.3133/sir20175113.

James, L.A., 1991, Incision and morphologic evolution of an alluvial channel recovering from hydraulic mining sediment: Geological Society of America Bulletin, v. 103, no. 6 , p. $723-736$.

Johnstone, J.A., and Mantua, N.J., 2014, Atmospheric controls on northeast Pacific temperature variability and change, 1900-2012: Proceedings of the National Academy of Sciences, v. 111, no. 40, p. 14360-14365.

Joint Institute for the Study of the Atmosphere and Ocean, 2019, The Pacific decadal oscilation (PDO): University of Washington and the National Oceanic and Atmospheric Administration, https://jisao.uw.edu/, accessed June 15, 2018.

Juracek, K.E., and Fitzpatrick, F.A., 2009, Geomorphic applications of stream-gage information: River research and applications, v. 25, no. 3, p. 329-347.

KCM, Inc., 1995, Lower Nooksack River Comprehensive Flood Hazard Management Plan — Nooksack River Flood History: Report prepared by KCM, Inc., for Whatcom County Flood Control Zone District.

Kerr Wood Leidal, 2008, Updated sediment analysis for lower Nooksack River (2039.008): Report prepared by Kerr Wood \& Leidal Associates for Whatcom County Flood Control Zone District, accessed October 2017 at, http://www. co.whatcom.wa.us/DocumentCenter/View/25522/sedimentanalysis-lower-NR-2008. 
Konrad, C.P., 2015, Geospatial assessment of ecological functions and flood-related risks on floodplains along major rivers in the Puget Sound Basin, Washington: U.S. Geological Survey Scientific Investigations Report 20155033, 28 p., http://dx.doi.org/10.3133/sir20155033.

Livneh B., Bohn, T.J., Pierce, D.S., Munoz-Ariola, F., Nijssen, B., Cayan, D., Vose, R., and Brekki, L.D., 2015, Development of a spatially comprehensive, daily hydrometeorological data set for Mexico, the conterminous U.S., and southern Canada-1950-2013: Nature Scientific Data, v. 2, 150042, doi:10.1038/sdata.2015.42.

Lisle, T.E., Cui, Y., Parker, G., Pizzuto, J.E. and Dodd, A.M., 2001. The dominance of dispersion in the evolution of bed material waves in gravel-bed rivers: Earth Surface Processes and Landforms, v. 26, no. 13, p.1409-1420.

Mantua, N.J., Hare, S.R., Zhang, Y., Wallace, J.M. and Francis, R.C., 1997, A Pacific interdecadal climate oscillation with impacts on salmon production: Bulletin of the American Meteorological Society, v. 78, no. 6, p.10691080 .

Northwest Hydraulic Consultants, 2015, Lower Nooksack River project alternatives analysis-Geomorphic characterization: Northwest Hydraulic Consultants.
Pittman, P.D., and Maudlin, M.R., 2003, Evidence of a major late Holocene river avulsion: Geological Society of America, Abstracts with Programs, v. 35, no. 6, p. 334.

Slater, L.J., Singer, M.B. and Kirchner, J.W., 2015, Hydrologic versus geomorphic drivers of trends in flood hazard: Geophysical Research Letters, v. 42, no. 2, p. 370-376.

U.S. Geological Survey, 2018, National Water Information System: U.S. Geological Survey website, https://waterdata. usgs.gov/wa/nwis.

Vose, R.S., Applequist, Scott, Squires, Mike, Durre, Imke, Menne, M.J., Williams, C.N., Jr., Fenimore, Chris, Gleason, Karin, and Arndt, Derek, 2014, NOAA's gridded climate divisional dataset (CLIMDIV): National Oceanic and Atmospheric Administration, National Climatic Data Center, accessed October 2, 2016, at https://data.nodc.noaa. gov/cgi-bin/iso?id=gov.noaa.ncdc:C00005.

Wise, D.R., Rinella, F.A., III, Rinella, J.F., Fuhrer, G.J., Embrey, S.S., Clark, G.E., Schwarz, G.E., and Sobieszczyk, S., 2007, Nutrient and suspended-sediment transport and trends in the Columbia River and Puget Sound Basins, 1993-2003: U.S. Geological Survey Scientific Investigations Report 2007-5186, 116 p. 

Publishing support provided by the U.S. Geological Survey Science Publishing Network, Tacoma Publishing Service Center

For more information concerning the research in this report, contact the Director, Washington Water Science Center

U.S. Geological Survey

934 Broadway, Suite 300

Tacoma, Washington 98402

https://www.usgs.gov/centers/wa-water 
z

$\frac{0}{0}$

今

웋

is

s

흘

。ั้

를

콩

홓

छ

ż

해을

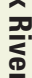

四

黑.

글 